\title{
EXECUTIVE REVIEW IN THE FRAGMENTED EXECUTIVE: STATE CONSTITUTIONALISM AND SAME-SEX MARRIAGE
}

\section{NORMAN R. WILLIAMS ${ }^{\dagger}$}

The past decade has witnessed a striking resurgence in interest in executive review-the notion that the President, no less than the judiciary, has the power to interpret and enforce the U.S. Constitution. ${ }^{1}$ Proponents of this view span the political spectrum from Michael Stokes Paulsen on the right to Larry Kramer on the left. ${ }^{2}$ While virtually everyone agrees that the President may veto legislation or pardon individuals convicted under a statute she considers unconstitutional, there has been considerable debate over whether the power of executive review includes the authority to refuse to enforce federal statutes that the President believes to be unconstitutional. ${ }^{3}$ It is this compo-

${ }^{\dagger}$ Assistant Professor of Law, Willamette University. A.B., Harvard University; J.D., New York University. Special thanks are owed to Ashutosh Bhagwat, Steve Bibas, Eric Claeys, and William Nelson, all of whom provided helpful comments on previous drafts. I am indebted to Hans Linde, who disagrees with much of what I say but who nevertheless generously shared his time and thoughts. I also thank Michael Elliot for his able research assistance and Willamette University College of Law, whose research grant made this possible.

${ }^{1}$ A useful definition of executive review has been proffered by Gary Lawson and Christopher Moore, who (with respect to executive review at the federal level) define it as "the President's power vel non to make and act upon constitutional judgments independently of the constitutional views of other departments." Gary Lawson \& Christopher D. Moore, The Executive Power of Constitutional Interpretation, 81 IOWA L. REV. 1267, 1280 (1996). For clarity, I use this definition, though in an expanded form to cover state executive officials' interpretation and enforcement of state constitutional provisions.

${ }^{2}$ See Larry D. Kramer, The People Themselves: Popular Constitutionalism AND JUDICIAL REVIEW 249 (2004) (proposing executive disregard of Supreme Court decisions as one possible response to an "overly assertive court"); Michael Stokes Paulsen, The Most Dangerous Branch: Executive Power to Say What the Law Is, 83 GEO. L.J. 217, 221 (1994) ("The President's power to interpret the law is, within the sphere of his powers, precisely coordinate and coequal in authority to the Supreme Court's.").

${ }^{3}$ Compare Frank H. Easterbrook, Presidential Review, 40 CASE W. RES. L. REV. 905, 914 (1990) (endorsing executive nonenforcement), and Peter L. Strauss, The President and Choices Not To Enforce, 63 LAW \& CONTEMP. Probs. 107, 112 (2000) (same), with Arthur S. Miller, The President and Faithful Execution of the Laws, 40 VAND. L. REV. 389, 391 (1987) (opposing executive nonenforcement), and Seth P. Waxman, Defending Congress, 79 N.C. L. REV. 1073, 1084-86 (2001) (opposing executive nonenforcement except when a congressional statute raises separation-of-powers concerns or when Supreme Court precedent clearly forbids enforcement). For an endorsement of a lim- 
nent of executive review that serves as the fault line in the constitutional discussion.

To date, the debate about the legitimacy and desirability of executive review has focused exclusively on the federal presidency. ${ }^{4}$ Despite the well-founded revival of interest in state constitutionalism, ${ }^{5}$ commentators have uniformly ignored the question of whether and to what extent state governors or other state officials may engage in executive review. This omission is all the more striking because one cannot simply transplant the federal model of executive review to the states. In contrast to the Hamiltonian federal executive with its unitary executive structure, ${ }^{6}$ state executives are not unitary. Instead, state constitutions fragment executive authority, providing for the direct popular election of several state officials and establishing relatively independent local governments. ${ }^{7}$ This fragmentation has serious implications for executive review at the state level.

Understanding these implications and how executive review works at the state and local levels is vital for both constitutional theory and practice. The vast bulk of executive officials in the nation work not for the President but for the fifty state governments and myriad local commissions and councils. While the federal government has roughly 2.7 million nonmilitary officials and employees, ${ }^{8}$ state and local gov-

ited nonenforcement power, see Dawn E. Johnsen, Presidential Non-Enforcement of Constitutionally Objectionable Statutes, 63 LAW \& CONTEMP. ProBs. 7, 11-12 (2000).

${ }^{4}$ See, e.g., Steven G. Calabresi \& Saikrishna B. Prakash, The President's Power To Execute the Laws, 104 YALE L.J. 541, 663 (1994) (arguing that the Constitution creates a unitary executive with the exclusive power to execute the laws); John O. McGinnis, Models of the Opinion Function of the Attorney General: A Normative, Descriptive, and Historical Prolegomenon, 15 CARDOZO L. REv. 375, 380-81 (1994) (evaluating the Attorney General's role in aiding the President to engage in independent constitutional interpretation).

${ }^{5}$ See, e.g., Paul W. Kahn, Interpretation and Authority in State Constitutionalism, 106 HARV. L. REV. 1147, 1147 (1993) (noting "renewed interest by bench and bar in the possibilities of state constitutionalism"); Jim Rossi, Institutional Design and the Lingering Legacy of Antifederalist Separation of Powers Ideals in the States, 52 VAND. L. REV. 1167, 117073 (1999) (assessing the separation of powers at the state level); see also Symposium, The Emergence of State Constitutional Law, 63 TEX. L. REv. 959 (1985) (providing a collection of scholarship on state constitutionalism).

${ }^{6}$ Indeed, the unitariness of the federal executive has played a central role in several commentators' endorsements of executive review. See Easterbrook, supra note 3, at 918 ("A unitary Executive always does better at avoiding chaos than does a hydraheaded, uncoordinated judiciary.”); Paulsen, supra note 2, at 321-31 (defending executive review by the President despite the "President's unique constitutional powers and position").

${ }^{7}$ See infra notes 31-32, 37-38 and accompanying text.

${ }^{8}$ U.S. Census Bureau, Federal Government Civilian Employment by Function 
ernments have 15.8 million officials and employees. ${ }^{9}$ Moreover, though the federal government is responsible for several vital areas of national life, the bulk of the regulatory and public policy programs that affect the daily lives of individuals-such as (to name just a few) education, domestic relations, land use, transportation, and professional and business licensing-are created and administered by state and local governments. Indeed, Americans interact more often with state or local officials, such as police officers, clerks at the Department of Motor Vehicles, and state university registrars, than they do with federal regulators. Given the prevalence and importance of state and local government in American life, it is crucial to understand to what extent, if any, state and local officials may engage in executive review.

Moreover, state and local executive review, though unexplored by academic commentators, has real, contemporary relevance for all Americans. Most recently, the authority of executive officials to refuse to enforce putatively unconstitutional laws attracted nationwide attention during the controversy regarding the issuance of marriage licenses to same-sex couples in San Francisco, California and Multnomah County, Oregon. There, local executive officials, acting on their own views of their respective state constitutions' guarantees of equality, issued marriage licenses to same-sex couples over the objection of their respective Governors and other state officials. ${ }^{10}$ Unable to command the county officials to stop their actions, the Governors of the two states sought judicial relief, and both state supreme courts ultimately enjoined the county officials from issuing marriage licenses to same-sex couples in violation of state statutes. ${ }^{11}$ Though the media

(Mar. 2004), available at ftp://ftp2.census.gov/govs/apes/04fedfun.txt

${ }^{9}$ See U.S. Census Bureau, 2004 Public Employment Data: State and Local Governments (July 2004), available at ftp://ftp2.census. gov/govs/apes/04stlus.txt.

${ }^{10}$ The contentious battles in San Francisco and Multnomah County in early 2004 had been precipitated by events elsewhere, most notably the Massachusetts Supreme Judicial Court's ruling in Goodridge v. Department of Public Health, 798 N.E.2d 941, 969 (Mass. 2003) (holding that limiting marriage to heterosexual couples violates the Massachusetts Constitution). See also Lawrence v. Texas, 539 U.S. 558, 560 (2003) (invalidating the Texas statute that criminalized homosexual sodomy); Halpern v. Toronto, [2003] O.R.3d 161, 161 (holding that a marriage statute violated equal protection provisions of Canada's Charter of Rights and Freedoms).

${ }^{11}$ See Lockyer v. City \& County of San Francisco, 95 P.3d 459, 464 (Cal. 2004) (holding that local executive officials lack the authority to allow same-sex marriages without a judicial determination to that effect); Li v. State, 110 P.3d 91, 102 (Or. 2005) (holding that marriage licenses issued to same-sex couples were "issued without authority and were void at the time that they were issued"). The San Francisco and Multnomah County officials were neither the first nor the only local officials to issue marriage licenses to same-sex couples. Thirty years ago, in 1975, the County Clerk in 
was preoccupied with the furor surrounding the issue of same-sex marriage, the courts did not pass on the constitutionality of same-sex marriage-indeed, they conspicuously and expressly refused to address the issue. ${ }^{12}$ Rather, each court rested its decision on the ground that the local officials did not have the authority to engage in executive review and to disregard statutory duties on constitutional grounds, even if the officials' constitutional concerns were valid. ${ }^{13}$

Although far from the only time the issue of executive review has arisen, the controversy regarding the California and Oregon officials' actions and the courts' responses to them provides an illuminating perspective from which to assess executive review at the state and local levels. The California and Oregon experiences demonstrate two interrelated propositions. First, unlike the Federal President, state governors often lack any meaningful ability to control state or local executive officials' exercise of executive review authority because of state constitutional provisions fragmenting executive authority. It is this fragmentation of the executive that makes such constitutional crises possible and, more importantly, inevitably leads governors or other officials to seek judicial resolution.

Second, there is a variety of ways in which state courts may respond to these claims of interpretive authority by autonomous execu-

Boulder, Colorado, issued licenses to six same-sex couples. Suzanne Herel, San Francisco Not the First To Marry Couples of the Same Gender, S.F. CHron., Feb. 14, 2004, at A16. The County Clerk discontinued the practice after the Colorado Attorney General expressed his opposition to the licenses' validity. Id. Similarly, while the San Francisco and Multnomah County controversies were raging, the County Clerk in Sandoval County, New Mexico, issued marriage licenses to a number of same-sex couples before the New Mexico Attorney General intervened, see Rona Marech, Gay Unions in New Mexico but State Forces County Clerk To Stop, S.F. CHRON., Feb. 21, 2004, at A13, and the Mayor of New Paltz, New York, similarly married several same-sex couples before the New York Attorney General intervened, see Thomas Crampton, Spitzer and New Paltz Mayor Meet About Gay Marriages, N.Y. TIMES, Mar. 12, 2004, at B4.

${ }^{12}$ See Lockyer, 95 P.3d at 464 ("[W] e emphasize that the substantive question of the constitutional validity of California's statutory provisions . . . is not before our court in this proceeding, and our decision in this case is not intended ... to reflect any view on that issue."); $L i, 110$ P.3d at 99 ("This court decides cases on subconstitutional grounds when it can, even if the parties present only constitutional arguments for the court's consideration. ... If . . . the marriage licenses at issue here were void $a b$ initio, ... this case is at an end." (citations omitted)).

${ }^{13}$ See Lockyer, 95 P.3d at 464 ("[L] ocal officials in San Francisco exceded their authority by taking official action in violation of applicable statutory provisions."); $L i, 110$ P.3d at 101 ("[T] he county erroneously transmogrified a governmental official's ongoing obligation to support the constitution into an implied grant of authority . . . to prescribe remedies for any perceived constitutional shortcomings in such laws without regard to the scope of the official's statutory authority to act."). 
tive officials. One model, which I label the judicial exclusivity model, rules out executive review on constitutional grounds because, according to this view, the task of enforcing the constitution is exclusively for the courts. ${ }^{14}$ Another model, which I call the legislative model, accepts in principle the constitutional propriety of executive review but cedes to the state legislature the power to determine which officials may consider constitutional claims in performing their statutory duties. ${ }^{15}$ Still a third model, pressed unsuccessfully by the county officials in San Francisco and Multnomah County, asserts that there is a constitutional right and corresponding obligation for all executive officials to interpret and enforce the constitution. Each of these models contains variations, but stated at this broad level of generality, these three models depict the terrain over which the various players in these debates have fought.

The central claim of this Article is that, as a constitutional matter, the legislative model best accords with state constitutional text and structure. In making this claim, I challenge the predominant judicial exclusivity model, which, I argue, rests upon an outdated and erroneous understanding of the respective roles of the three branches of government in interpreting and enforcing the constitution. At the same time, I also reject the diametrically opposite theory that all executive officials have a constitutional right to engage in executive review. While I acknowledge that constitutional officers, such as the governor, may engage in executive review as part of the discharge of their constitutionally assigned powers and duties, I endorse and defend the legislative model, which leaves it to the legislature to determine whether and to what extent the myriad nonconstitutional officers employed by state and local governments may engage in executive review.

Of course, one might doubt whether such a global assessment of state executive review can be made in a coherent or profitable fashion. After all, there are fifty states, each with its own constitution. Nevertheless, while there is no denying that differences among state constitutional texts exist, there is also no denying that substantial similarities exist. And, when it comes to assessing executive review, the pertinent constitutional provisions do not differ in a material way. For

\footnotetext{
${ }^{14}$ See Lockyer, 95 P.3d at 474 ("The Courts ... constitute the proper forum for determination of the validity of State statutes.").

${ }^{15}$ See Li, 110 P.3d at 101 ("The agency's duty to decide [constitutional] challenges would not be doubted if the legislature provided for it expressly ...." (quoting Cooper v. Eugene Sch. Dist., 723 P.2d 298, 303 (Or. 1986))).
} 
example, every state has adopted a tripartite system of government with a popularly elected governor as head of the executive branch. ${ }^{16}$ Moreover, most state constitutions contain an express provision regarding the separation of powers (rather than relying on such a principle by implication as does the U.S. Constitution), and the wording of the provisions is strikingly similar. ${ }^{17}$ These features of state constitutional structure provide the substrate of arguments regarding executive review, and because of their similarity across states, one can intelligibly assess state executive review as a general phenomenon.

Part I sets the stage for assessing the three judicial models by identifying the extent to which state constitutions fragment executive authority. This Part demonstrates that it is the fragmented nature of executive authority that leads to intraexecutive constitutional disputes, such as those involving the issuance of marriage licenses to same-sex couples. These disputes, in turn, often necessitate judicial involvement to mediate and resolve the constitutional disagreement. Part II begins the investigation of how courts address these intraexecutive disputes, taking up the judicial exclusivity model, which rules out executive review and the intraexecutive disputes that it produces as illegitimate because the constitution is exclusively for the judiciary to enforce. Though most states have adopted this approach, this model rests on an erroneous conception of the separation of powers and the respective roles of the three branches in interpreting and enforcing the constitution. Indeed, contrary to conventional wisdom, I argue that there is no constitutional prohibition against executive review even by local officials- the circumstance that engenders the most fear among courts. Part III considers the opposite extreme: that all executive officials have a constitutional right to engage in executive review. As I demonstrate, this view likewise rests on a faulty understanding of the powers and obligations of executive officials.

Between these two extremes lies the legislative model, which Part IV describes and endorses. The legislative model assigns to the legislature the responsibility for determining whether and which administrative officers may engage in executive review. As I explain, this

\footnotetext{
${ }^{16}$ See John Devlin, Toward a State Constitutional Analysis of Allocation of Powers: Legislators and Legislative Appointees Performing Administrative Functions, 66 TEMP. L. REV. 1205, 1221 (1993) ("Governments in all states are organized similarly to their federal counterpart, sharing both the familiar tripartite allocation of powers ... and some degree of interbranch 'checks and balances' ....").

${ }^{17}$ See id. at 1236-37 (surveying the ways in which states explicitly constitutionalize the separation of powers).
} 
model best coheres with the state constitutional structure and promotes the greatest degree of flexibility. The legislature's power to regulate executive review, though, does not extend to governors and other constitutional officers, whose constitutionally assigned duties necessarily include the power to engage in executive review.

Part $\mathrm{V}$ concludes the analysis by assessing the prevalence and significance of intraexecutive disputes among constitutional officers regarding the meaning of the constitution. As might be surmised, executive review at the state level differs markedly from that at the federal level. Because of the fragmented nature of state executive power, disputes within the "executive branch" regarding what the state constitution means are inevitable. Such disputes inexorably invite a greater judicial role than that required at the federal level, where intraexecutive disputes are resolved internally by the Department of Justice's Office of Legal Counsel acting on instructions from the President. ${ }^{18}$ More importantly, such intraexecutive disputes will often become public, as they did in California and Oregon with regard to same-sex marriage, and thereby focus popular attention on competing constitutional views. In this way, executive review in a fragmented executive, though producing greater political turbulence, fosters heightened popular participation in constitutional debates.

\section{THE FRAGMENTED EXECUTIVE}

\section{A. The Executive and State Constitutions}

In the federal government, intraexecutive disputes regarding the Constitution rarely become public, much less necessitate a judicial resolution, because the President has the ultimate authority to resolve such disputes. As a constitutional matter, the President possesses significant control over the executive branch. She appoints superior executive officers (with the advice and consent of the Senate), ${ }^{19}$ and, although the Supreme Court has upheld congressional restrictions on the President's authority to remove certain executive officers, ${ }^{20}$ Con-

${ }^{18}$ See infra notes 25-28 and accompanying text.

${ }^{19}$ U.S. CONST. art. II, $§ 2$, cl. 2.

${ }^{20}$ See, e.g., Morrison v. Olson, 487 U.S. 654, 691-93 (1988) (upholding a law limiting the President's authority to remove independent counsels except for "good cause"); Wiener v. United States, 357 U.S. 349, 356 (1958) (rejecting the President's attempt to remove members of the War Claims Commission); Humphrey's Ex'r v. United States, 295 U.S. 602, 632 (1935) (limiting the power of the President to remove members of the Federal Trade Commission). 
gress may not unduly handicap the President's ability to supervise the executive branch. ${ }^{21}$ Moreover, as Elena Kagan has persuasively noted, to whatever extent the Constitution requires a unitary executive structure, Congress has not as a statutory matter sought to displace the unitary executive. ${ }^{22}$ Congress has used its authority to insulate agency heads from direct presidential removal sparingly, ${ }^{23}$ and, even with respect to the few so-called "independent agencies," the President retains significant levers of control and influence, such as the power of appointment. ${ }^{24}$

More importantly for present purposes, agencies are not free to develop and act upon their own conception of the U.S. Constitution. The Department of Justice's Office of Legal Counsel (OLC) provides legal guidance to agencies that request it, ${ }^{25}$ and, when litigation with a private party takes place, agencies must generally rely upon (and abide by decisions made by) the Department's litigating divisions. ${ }^{26}$ True, some agencies are exempt from direct control by the Department of Justice, ${ }^{27}$ but, in those cases, the other levers of control and influence possessed by the President typically ensure that the agencies conform their legal views to those of the President.

Thus, for example, were a regional forest manager to harbor some doubts about the constitutionality of some federal statutory mandate, the secretary of agriculture could ask OLC to provide an opinion. OLC's opinion, which would reflect the President's views given that the assistant attorney general is a presidential appointee removable at will by the President, ${ }^{28}$ would resolve the matter. Were the forest

${ }^{21}$ See Morrison, 487 U.S. at 691-93 (suggesting that the President's ability to fire an official "for good cause" is constitutionally required so as to preserve presidential authority)

${ }^{22}$ Elena Kagan, Presidential Administration, 114 HARV. L. REV. 2245, 2320 (2001).

${ }^{23}$ See, e.g., 44 U.S.C. \$ 3502(5) (2000) (listing “independent regulatory agenc[ies]”).

${ }^{24}$ See, e.g., James Q. Wilson, BurEaUCRACY 260-62 (1989) (discussing the influence of presidential appointees on agency policies)

${ }^{25}$ See 28 U.S.C. $\$ 512$ (2000) (providing that head of an executive department may require an opinion from the Attorney General). The Attorney General has delegated this opinion-drafting authority to the OLC. See 28 C.F.R. $§ 0.25$ (a) (2005). While no agency is required to seek such opinions, they often do so.

${ }^{26}$ See 28 U.S.C. $\$ 516$ (2000) ("Except as otherwise authorized by law, the conduct of litigation in which the United States, an agency, or officer thereof is a party, or is interested, ... is reserved to officers of the Department of Justice, under the direction of the Attorney General.").

${ }^{27}$ See 2 Fed. Proc., L. Ed. $§ 2: 28$ (2003) (noting that Congress has exempted certain types of litigation from Department of Justice control).

${ }^{28}$ See McGinnis, supra note 4, at 421 (noting the White House's influence on the 
manager to continue to refuse to enforce the statutory mandate on the basis of her own contrary view, the President could simply order the forester to enforce the statute, and the President's decision would end the matter. ${ }^{29}$ There would be no need for the President to seek a court order directing the forester to comply with the statute. And, because the President could sanction the forester in a variety of ways, including potentially firing the forester, ${ }^{30}$ the forester would be unlikely to take such unilateral action in the first place.

The President's ability to control the federal executive branch stands in sharp contrast to the authority of state governors with respect to state executive officials and agencies. Unlike the federal executive branch, in which all executive officials are accountable more or less to the President, state executive branches are fragmented in ways that make it easier for intraexecutive disagreements to arise and manifest. To begin with, the governor is not the only executive official elected by the people of the state. With four exceptions, every state constitution requires the popular election of other state officials, such as the attorney general, secretary of state, or superintendent of public instruction. ${ }^{31}$ In fact, more than two-thirds of the states have

\footnotetext{
assistant attorney general).

${ }^{29}$ See, e.g., James F. Blumstein, Regulatory Review by the Executive Office of the President: An Overview and Policy Analysis of Current Issues, 51 DukE L.J. 851, 887-88 (2001) (describing how President Clinton directed agencies to take specified actions).

${ }^{30}$ See Myers v. United States, 272 U.S. 52, 163-64 (1926) (holding that the President has constitutional authority to remove purely executive officials).

${ }^{31}$ Ala. CONST. art. V, § 114; ALASKa CONST. art. 3, §§ 2, 3, 7, 8; ARIZ. CONST. art. V, $§ 1$; ARK. CONST. art. $6, \S \S 1$, 3; CAL. CONST. art. V, § 11; COLO. CONST. art. IV, §§ 1,

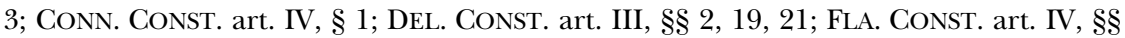
1, 2, 4, 5; GA. CONST. art. V, § 1, paras. 1, 3, art. V, § 3, para. 1; HAw. ConsT. art. V, §§ 1, 2; IDAHO CONST. art. IV, §§ 1, 2; ILL. CONST. art. V, § 1; IND. CONST. art. 5, §§ 1, 2, 3, art. $6, \S 1$; IOWA CONST. art. IV, $\S \S 1,2,3,22$; KAN. CONST. art. $1, \S 1$; KY. CONST. $\S \S 70$, 91; LA. ConsT. art. IV, $\S \S 1 \mathrm{~A}, 3 \mathrm{~A}$; MD. CONST. art. II, $\S \S 1$, 1A, art. V, § 1, art. VI, § 1; MASS. CONST. pt. 2, ch. 2, § I, arts. I, II, pt. 2, ch. 2, § II, art. I; MICH. CONST. art. V, § 21; Minn. Const. art. V, $§ 1$; Miss. Const. art. 5, $\S \S 116,128,133,134$; Mo. ConsT. art. IV, § 17; MONT. CONST. art. VI, §§ 1, 2; NEB. CONST. art. IV, § 1; NEV. CONST. art. 5, $\S \S 2,19$; N.M. CONST. art. V, § 1; N.Y. CONST. art. IV, $\S 1$, art. V, § 1; N.C. CONST. art. III, $\S \S 2$, 7; OHIO CONST. art. 3, § 1; OKLA. CONST. art. VI, § 1, 4; OR. CONST. art. V, § 1, 4 , art. VI, $\S 1$; PA. CONST. art. IV, $\S \S 1,2$, 4, 18; R.I. CONST. art. IX, § 1; S.C. CONST. art. VI, § 7; S.D. CONST. art. IV, §§ 2, 7; TEX. CONST. art. 4, §§ 1, 2; UTAH CONST. art. VII, § 1; VT. CONST. ch. II, $\S \S 47,48$; VA. CONST. art. V, $\S \S 2,13,15$; WASH. CONST. art. III, $\S$ 1 ; W. VA. CONST. art. VII, $\S 7-1,7-2$; WIS. CONST. art. V, $\S 3$, art. VI, $\S 1$; WYO. CONST. art. IV, $\S \S 3,11$.

North Dakota has the most constitutionally prescribed elected officials with thirteen. N.D. CONST. art. V, $\$ 2$ (governor, lieutenant governor, agriculture commissioner, attorney general, auditor, insurance commissioner, three public service commissioners, secretary of state, superintendent of public instruction, tax commissioner,
} 
four or more officials elected on a statewide basis. ${ }^{32}$ Because these officials are neither appointed by the governor nor (more importantly) removable by her, the governor has little or no formal influence over how these officials perform their constitutionally assigned duties. Moreover, because the elections for these other offices are often partisan, the officials may come from a different party than the governor. ${ }^{33}$ In such instances, not only do the officials commonly possess different views regarding the state constitution, the governor's political influence over the officials is at its nadir-the officials' political futures do not necessarily lie with the governor but in undermining her. Indeed, other elected executive officials are often happy to "stick it to" the governor for partisan political gain by either upstaging the governor or rebuffing her, thereby making the governor seem powerless and/or ineffective.

Further complicating the governors' ability to coordinate the enforcement of state law, state constitutions also create local governments insulated from direct gubernatorial control. There is, in some respects, a rough analogy between the federal government and the states, on one hand, and state governments and local governments on the other. One might view local governments as occupying a similar position vis-à-vis the state government as states do vis-à-vis the federal government. There is some utility to this analogy-a point that I explore further below ${ }^{34}$-but the comparison is not technically accurate. Unlike the states, which are sovereign entities that predate and exist independently of the federal government, local governments are created by state law and act as components of the state government. ${ }^{35}$ Moreover, while local governments do administer local ordinances, the administration and enforcement of state law is a central function

and treasurer). Only Maine, New Hampshire, New Jersey, and Tennessee have no constitutionally prescribed, popularly elected executive officials other than the governor. ME. Const. art. V, pt. 1, $\S \S 1,2,8$; N.H. ConST. pt. 2, arts. 41, 42, 60 (governor and five advisory councilors); N.J. CONST. art. V, § 1, paras. 1, 4; TENN. CONST. art. III, $\S \S 1,2 ; c f$. G. Alan TARR, UNDERSTANDING STATE CONSTITUTIONS 17 (1998) (“[M]ost state executive articles establish a nonunified executive.").

${ }^{32}$ TARR, supra note 31 , at 17.

${ }^{33}$ Interestingly, the California Constitution requires that all city and county officer elections be nonpartisan. CAL. CONST. art. II, §6(a).

${ }^{34}$ See infra text accompanying notes 193-200.

${ }^{35}$ See, e.g., CAL CONST. art. XI, § 1(a) (providing that counties "are legal subdivisions of the State”); CAL. GOV’T CODE $\$ 23002$ (West 2003) (same); see also Richard Briffault, Home Rule for the Twenty-First Century, 36 URB. LAW. 253, 257 (2004) (" $[\mathrm{H}]$ ome rule does not raise local governments to the level of sovereign entities within our system."). 
of local government (e.g., local police officers enforcing state criminal law). The same cannot be said for state governments with respect to federal law. ${ }^{36}$

That local governments are not sovereign entities akin to state governments under the federal constitutional system does not mean, however, that local governments are vassal entities subject to plenary supervision by state officials. Rather, local governments have their own legislative, executive, and (often) judicial departments, and they possess a good deal of autonomy from the state government. ${ }^{37}$ Fortyone states provide some form of "home rule" autonomy to their local governments. ${ }^{38}$ The precise structure of local governments and the extent of local autonomy vary from state to state and even within a state. $^{39}$ It is beyond the scope of this Article to catalogue the various types of local governments, but one can begin to get a feel for the problem facing modern governors by considering the California model, which is by no means exceptional. ${ }^{40}$

The California Constitution mandates the establishment of county governments and provides for the creation of city governments. ${ }^{41}$ Cities and counties may either draft their own charters or rely on the state legislature to shape the structure and powers of the local government. ${ }^{42}$ Once established, the local governments possess a good deal of legislative authority. The state constitution empowers them to adopt ordinances regarding municipal matters, some of which the state legislature may not preempt. ${ }^{43}$ As others have observed, these

\footnotetext{
${ }^{36}$ There are, to be sure, federal statutes administered by state officials subject to federal supervision-for example, the Clean Air Act-but most federal regulatory statutes are enforced by federal officials, and there is even some constitutional limitation on the use of state officials. See, e.g., Printz v. United States, 521 U.S. 898, 924 (1997) (concluding that Congress may not mandate state executive participation in federal regulatory programs).

${ }^{37}$ See TARR, supra note 31, at 20 (noting that most states have "home rule" provisions for local governments); Richard Briffault, Our Localism: Part I-The Structure of Local Government Law, 90 COLUM. L. REV. 1, 1 (1990) (noting that many local governments possess considerable autonomy in matters of local concern).

38 Briffault, supra note 37 , at 10-11.

${ }^{39}$ Briffault, supra note 35, at 253. See generally DALE KrANE ET AL., Home RUle IN AMERICA: A FIFTY-STATE HANDBOOK (2001) (providing an overview of various states' approaches to local government).

${ }^{40}$ See Michele Timmons et al., County Home Rule Comes to Minnesota, 19 WM. MitCheLL L. REV. 811, 817 (1993) (noting that, while California was first to allow county home rule in 1911, as of 1993, thirty-six states permitted county home rule).

${ }^{41}$ CAL. CONST. art. XI, $\S \S 1,2$.

${ }^{42} I d . \S 3$.

${ }^{43}$ For example, charter cities may adopt and enforce ordinances "in respect to
} 
"home rule" provisions provide a considerable degree of legislative autonomy to local governments. ${ }^{44}$

More important for present purposes, both the state constitution and state statutes guarantee a great deal of autonomy for local executive officials. The California Constitution expressly requires that certain county officials, such as the sheriff, district attorney, and assessor, be elected by the people of the county ${ }^{45}$ and allows charter counties to specify in their charter whether other county officials are elected or appointed (and, if the latter, by whom). ${ }^{46}$ For noncharter counties, the legislature has provided that certain local officials beyond those identified in the constitution, such as the county clerk and recorder, shall be elected by the local voters. ${ }^{47}$ Similarly, the constitution gives charter cities "plenary" authority to decide the method of selection and removal of city officials. ${ }^{48}$ For noncharter cities (so called "general law cities"), the legislature has provided for government by a city council of at least five members who are elected by the local voters either by or from districts. ${ }^{49}$ Each city may decide whether to have an

municipal affairs," and such charters "with respect to municipal affairs shall supersede all laws inconsistent therewith." Id. §5(a). This grant of power empowers charter cities to adopt measures that conflict with state law-a sort of reverse-preemption provision-though California courts have struggled to identify the contours of the "municipal affairs" protected against state interference. See Johnson v. Bradley, 841 P.2d 990, 1004 (Cal. 1992) (upholding Los Angeles charter provision providing for partial public financing of municipal elections despite contrary state law). Even noncharter local governments possess legislative authority over municipal affairs. See CAL. CONST. art. XI, $\S 7$ (empowering all cities and counties to make and enforce municipal ordinances "not in conflict with general laws").

${ }^{44}$ Jared Eigerman, California Counties: Second-Rate Localities or Ready-Made Regional Governments?, 26 HASTINGS CONST. L.Q. 621, 664-68 (1999). Strictly speaking, Mayor Newsom did not invoke "home rule" authority for his actions; he did not, for example, seek passage of a local ordinance providing for municipal marriage licenses. Briffault, supra note 35 , at 254 n.8. Rather, he claimed that the state constitution empowered him to enforce a state law in a particular way so as to avoid what he viewed as unconstitutional conduct. $I d$.

Interestingly, in the late 1990s, the San Francisco Board of Supervisors-the legislative branch of the City and County of San Francisco-considered an ordinance regarding same-sex domestic unions. In Lockyer v. City and County of San Francisco, however, the California Supreme Court made clear that, because marriage is a statewide concern, any municipal ordinance conflicting with state law would be void. 95 P.3d 459, 471 (Cal. 2004).

${ }^{45}$ CAL. CONST. art. XI, $\S 1(\mathrm{~b})$.

${ }^{46} I d . \S 4(\mathrm{c})$.

${ }^{47}$ CAL. GOV’T CODE $\$ 24009$ (a) (West 2003).

${ }^{48}$ CAL. CONST. art. XI, $\$ 5$ (b) (4).

${ }^{49}$ CAL. GOV’T CODE $\$ \S 34871,36501$ (West Supp. 2005). The mayor may be selected by the city council from among its membership or elected by the people of the 
elected mayor. ${ }^{50}$ Critically, neither the state constitution nor any state statute empowers the governor to either appoint or remove city or county executive officials. ${ }^{51}$ Rather, removal of an elected local official may only take place by recall election or as provided by local ordinance. ${ }^{52}$ Thus, while nominally the governor may be the chief executive of California, her power over local officials is virtually nonexistent.

It is this fragmentation of executive authority that makes intraexecutive disputes regarding the meaning of the federal and state constitutions possible. Because the governor often has no direct authority over other elected state and local officials, those officials are free to disagree with the governor regarding the meaning of the constitution and its implications for the enforcement of state regulatory programs. Indeed, it was this fragmentation of executive authority that made the recent controversy over same-sex marriage licenses in California and Oregon possible.

\section{B. A Case in Point: Same-Sex Marriages}

The recent events in California and Oregon regarding the issuance of marriage licenses to same-sex couples obviously generated intense feelings among those both in favor of and opposed to such marriages. While the protagonists in the debate focused primarily upon the merits of the underlying constitutional question-whether the federal or state constitutional guarantees of equality required recognition of same-sex marriages-the equally important issue regarding how such a disagreement among state and local officials could arise in the first place received virtually no attention. Once one focuses closely on the actual distribution of power and responsibility among the various officials involved in the dispute, though, it becomes immediately apparent that it was the fragmentation of executive authority that led to this controversy and, moreover, that promises future constitutional disputes among state and local officials regarding other subjects.

city. CAL. GOV’T CODE $§ 34881$ (West 1998); see also id. $§ 34102$ (defining noncharter cities as "general law cities"). 1988).

${ }^{50}$ CAL. Gov’T Code $§ 34871$ (West Supp. 2005); CAL. GOV’T Code $§ 34900$ (West

See CAL. GOV'T CODE $§ 36503$ (West Supp. 2005) (providing that elected city officials shall remain in office until successors are elected and qualified); CAL. GOV'T CODE $§ 24201$ (West 2003) (same as to county officials).

${ }^{52}$ CAL. CONST. art. II, $§ 19$. 


\section{California}

Under California law, it is the county clerks and recorders who administer the state's marriage statute. The county clerk issues marriage licenses and certificates of registry. ${ }^{53}$ Once the marriage is solemnized, the executed marriage license is returned to the county recorder, who registers the marriage and transmits the license to the state registrar of vital statistics for review and recordation. ${ }^{54}$

On January 8, 2004, Gavin Newsom was sworn in as mayor of the City and County of San Francisco. ${ }^{55}$ Though he had not campaigned on the issue, on February 10, 2004, the new Mayor instructed the San Francisco County Clerk to revise the state-crafted marriage license form "in order to provide marriage licenses on a nondiscriminatory basis, without regard to gender or sexual orientation." ${ }^{56}$ Expressly referencing judicial developments in other states, Mayor Newsom explained that, in his view, the California Constitution's equal protection clause prohibited discrimination against gay and lesbian couples with regard to marriage. ${ }^{57}$ The County Clerk complied with the Mayor's instructions and, on February 12, 2004, began issuing marriage licenses to same-sex couples. ${ }^{58}$ At the same time, the County Assessor-Recorder began registering marriages of same-sex couples who had received such licenses and solemnized their marriage. ${ }^{59}$

State officials reacted almost immediately to Newsom's actions. A day after the city began issuing licenses, an official at the State De2004)

53 CAL. FAM. Code $\S 350$ (a) (West Supp. 2005); CAL. FAM. CODE $§ 359$ (a) (West

${ }^{54}$ See CAL. FAM. CODE $\$ 423$ (West 2004) (requiring the person solemnizing a marriage to return the marriage certificate to the county recorder); CAL. HEALTH \& SAFETY CODE $\$ 102285$ (West 1996) (stating that the county recorder acts as the local registrar of marriages); CAL. HEALTH \& SAFETY CODE $§ 102355$ (West 1996) (requiring the local registrar to transmit registered marriage certificates to the state registrar on a monthly basis); CAL HEALTH \& SAFETY CODE $§ 102225$ (West 1996) (providing that the state registrar shall return "unsatisfactory" marriage certificates to the local registrar).

${ }^{55}$ San Francisco has a unique status under California law; as permitted under the state constitution, it has merged its city and county governments. See CAL. Const. art. XI, §6(a) (permitting such consolidation via charter).

${ }^{56}$ See Lockyer v. City \& County of San Francisco, 95 P.3d 459, 464, 465 n.4 (Cal. 2004) (quoting Mayor Newsom's letter to the San Francisco County Clerk).

${ }^{57} I d$.

${ }^{58}$ Rachel Gordon, S.F. Defies Law, Marries Gays; Legal Battle Looms: City Hall Ceremonies Spur Constitutional Showdown, Injunction Threat, S.F. CHRON., Feb. 13, 2004, at A1. On the first day alone, the city issued 118 licenses. Id.

${ }^{59}$ See Lockyer, 95 P.3d at 465 (noting that the County Recorder registered solemnized same-sex marriages). 
partment of Health and Human Services questioned whether the licenses were valid and hinted that the state would refuse to register marriages conducted pursuant to the licenses. ${ }^{60}$ A week later, Governor Arnold Schwarzenegger announced his opposition to San Francisco's actions. ${ }^{61}$

That the Clerk and Recorder followed Mayor Newsom's instruction and not the Governor's was understandable. Under the San Francisco charter, the county clerk is accountable indirectly to the mayor, who may appoint and remove the clerk with the concurrence of the city administrator (herself a mayoral appointee). ${ }^{62}$ The county assessor-recorder, in turn, though not appointed by the mayor, is an elected official accountable to the same electorate (and therefore subject to the same popular pressures) as the mayor. ${ }^{63}$ At the same time, the governor lacks the power to remove either the county clerk or the assessor-recorder. ${ }^{64}$ As a consequence of this structural arrangement, neither the County Clerk nor the Assessor-Recorder had any incentive to accede to demands by state officials, particularly when there were

${ }^{60}$ Harriet Chiang et al., Mad Dash to S.F. City Hall To Say 'I Do,' 2 Groups Trying to Halt Same-Sex Unions Must Wait Until Tuesday, S.F. CHRON., Feb. 14, 2004, at A1 (reporting the statement of Terry Delgadillo, Deputy Director, California Department of Health and Human Services).

${ }^{61}$ See Press Release, Office of the Governor, Statement of Gov. Schwarzenegger on Same-Sex Marriage (Feb. 17, 2004), http://www.governor.ca.gov/govsite/press_release/ 2004_02/20040217_GAAS6904_Same_Sex_Marriage_Statment.html (“California's law ... defines marriage as being between a man and a woman."); Press Release, Office of the Governor, Statement of Gov. Schwarzenegger on Same-Sex Marriage Lawsuit by San Francisco (Feb. 19, 2004), http://www.governor.ca.gov/govsite/press_release/ 2004_02/20040219_GAAS7304_SameSex_Marriage_Lawsuit.html ("The marriage certificates submitted to the Department of Health Services by the City and County of San Francisco fail to meet legal standards.”).

${ }^{62}$ See S.F., CAL., CHARTER $\$ 18.105$ (transferring the functions of the county clerk to the city administrator effective July 1,1997 ); $i d$. $\$ 3.104$ (providing for the appointment and removal of the city administrator by the mayor, subject to board of supervisors approval). Together with the mayor, the city administrator may appoint and remove department heads, such as the director of administrative services. S.F., CAL., CHARTER § 3.104(6). The Office of the County Clerk is a division within the Department of Administrative Services. At the time of the Lockyer litigation, the director of administrative services was Daryl M. Burton, who had delegated his powers as county clerk for San Francisco to Nancy Alfaro, the Director of the Office of the County Clerk. Lockyer, 95 P.3d at 464 n.3.

${ }^{63}$ S.F., CAL., CHARTER $§ \S 3.101,6.100$.

${ }^{64}$ The assessor-recorder is subject to recall by election for any reason or removal by a three-fourths vote of the board of supervisors for official misconduct. S.F., CAL., CHARTER $\$ \S 14.103,15.105$ (a). In addition, the city ethics commission may remove any city official upon conviction for a felony involving moral turpitude where the commission believes the crime warrants removal. S.F., CAL., CHARTER § 15.105(c). 
local political benefits to be reaped. ${ }^{65}$ Thus, regardless of to whom the local officials nominally reported, ${ }^{66}$ the County Clerk and Assessor-Recorder followed the Mayor's instructions. ${ }^{67}$

The inability to directly compel the County Clerk to stop issuing licenses led Governor Schwarzenegger to search for other mechanisms to obtain the county officials' compliance with state law. On February 25, the State Registrar of Vital Statistics, who is a gubernatorial appointee, ${ }^{68}$ issued a directive to the County Recorder ordering that the registration of same-sex marriages be stopped. ${ }^{69}$ At least on the surface, the state registrar's influence over the marriage process is considerable. The state registrar prescribes the form of the marriage

${ }^{65}$ In California, opponents of same-sex marriage outnumbered supporters. See Rona Marech, Leno to Counter Bush on Gay Marriage; Bill Would Recognize Licenses, Boost Benefits, S.F. Chron., Jan. 24, 2004, at A15 (reporting an August 2003 statewide poll in California showing that fifty percent of California voters opposed same-sex marriages, while forty-two percent supported them); Mark Simon \& Carla Marinucci, Top State Dems Criticize S.F. Mayor; Tightrope: Politicians Try Not To Anger Voters-50\% of Californians Oppose Same-Sex Unions, S.F. CHRON., Feb. 20, 2004, at A1 (reporting a February 2004 poll showing that same-sex marriage opponents outnumbered supporters fifty percent to forty-four percent). Nevertheless, in the liberal bastion of San Francisco, supporters outnumbered opponents. See Rachel Gordon, Acceptance of Gay Marriage Growing in State Field Poll; Half of Voters Still Against It-But Even More Oppose Constitutional Ban, S.F. Chron., Feb. 26, 2004, at A1 (reporting a poll showing that, in the San Francisco Bay Area, supporters of same-sex marriage outnumbered opponents fiftyseven percent to thirty-seven percent).

${ }^{66}$ By statute, the governor is entitled to "supervise the official conduct of all executive and ministerial officers.” CAL. GOV’T CODE $§ 12010$ (West 2005). The statute, however, does not identify whether local officials are included within its purview, and, even if so, the insulation afforded local officials under the California Constitution and statutes renders illusory any supervisory power held by the governor as a practical matter.

${ }^{67}$ In Lockyer, the California Supreme Court questioned whether, as a legal matter, the County Clerk and Recorder were obligated to follow the Mayor's instructions. 95 P.3d at 471-72 (noting that, because statutes assigned duties to the County Clerk and Recorder, the Mayor was not authorized to direct the performance of their statutory duties). My point is only that, as a practical matter, the county clerk will follow the mayor's instructions.

${ }^{68}$ By statute, the state director of health services serves as the state registrar. CAL. HEALTH \& SAFETY CODE $§ 102175$ (West 1996). The director is a gubernatorial appointee, subject to senate confirmation, who serves at the governor's pleasure. Id. $\S$ 100105.

${ }^{69}$ Governor Schwarzenegger had previously announced his view that the marriage licenses were invalid and could not be registered under state law. See Simon \& Marinucci, supra note 65, at A1 (reporting Governor Schwarzenegger's comment that "[t]he marriage certificates submitted to the Department of Health Services by the city and county of San Francisco fail to meet legal standards"); see also Lockyer, 95 P.3d at 466 (noting that the State Registrar issued a directive to the San Francisco County Recorder, which was ignored). 
license and certificate and has the responsibility of registering solemnized marriages. ${ }^{70}$ The state registrar has no enforcement authority with regard to county clerks' issuance of marriage licenses, but she does have "supervisory power" over the county recorders. ${ }^{71}$ Moreover, county recorders who fail to perform their duty in accordance with the instructions of the state registrar are potentially subject to criminal punishment. $^{72}$

Despite the State Registrar's directive, the San Francisco County Recorder continued to register same-sex marriages. ${ }^{73}$ Once again, the Registrar's power was more formal than real. While the state registrar is nominally the supervisor of county recorders, the state registrar has no authority to sanction, much less remove, a county recorder who disobeys the registrar's instructions. Even the threat of criminal punishment is beyond the authority of the state registrar; the decision whether to indict the county recorder for failing to follow the state registrar's commands falls to the county district attorney, a locally elected official. $^{74}$

Moreover, the State Registrar's refusal to register the marriage certificates proved to be a largely useless tool. First, recordation by the State Registrar came too late in the process; by that time, the marriage licenses had already been issued, the marriages solemnized, and the marriage certificates recorded by the County Recorder. Second and relatedly, it was far from clear that recordation by the State Registrar was essential to the validity of the marriages. State law itself expressly provided that marriages were not invalid merely because of a

${ }^{70}$ See CAL. Health \& SAFETy CODE $\$ 103125$ (West 1996) (providing that the state registrar prescribe the form of both the marriage license and certificate).

${ }^{71}$ Id. $\$ 102180$.

${ }^{72}$ See id. $\$ 103790$ (providing that a failure to perform duties qualifies as a misdemeanor).

${ }^{73}$ See Lockyer, 95 P.3d at 466 (noting that the County Recorder ignored the State Registrar's directive).

${ }_{74}$ As a formal matter, the attorney general supervises the conduct of district attorneys and must initiate prosecutions when she believes a law is not being adequately enforced by a district attorney. See CAL. CONST. art. V, § 13 ("Whenever in the opinion of the Attorney General any law of the State is not being adequately enforced in any county, it shall be the duty of the Attorney General to prosecute any violations of the law ....”). This power, however, is rarely invoked. See JOSEPH R. GRODIN ET AL., THE CALIFORnia STATE CONSTITUTION: A REFERENCE Guide 114 (1993) (“[T]he attorney general's power to intervene in the operations of the county district attorneys has rarely been invoked."). Indeed, given Attorney General Lockyer's stated sympathy for same-sex couples (and his political ambitions), see infra notes 81-83 and accompanying text, it is hardly surprising that he did not seek criminal indictment of AssessorRecorder Teng. 
mistake or omission by a state official, ${ }^{75}$ and a 1943 opinion of the California Attorney General had indicated that the registrar does not have the authority to determine the validity of marriages as part of the recordation process. ${ }^{76}$ While opponents of same-sex marriage contended that the statutory safe harbor was inapplicable to marriage licenses that were issued to individuals who were not statutorily entitled to marry-a view that the California Supreme Court ultimately endorsed $^{77}$-doubt surrounding the point at the time was sufficient to place private employers and other state and local governments in a difficult position regarding whether to treat the marriages as valid. ${ }^{78}$ Stated bluntly, no one was sure that, because of the absence of registration by the State Registrar, the marriage certificates were just pieces of paper with no legal significance.

With all other options having failed to resolve the crisis, on February 20, the Governor sent a letter to Attorney General Lockyer, directing him to take "immediate steps" to obtain a court order that the marriages were illegal. ${ }^{79}$ Once again, the Governor encountered difficulties. Under California law, it is the attorney general, not the governor, who is empowered to see to it that the laws are "uniformly and

${ }^{75}$ See CAL. FAM. CODE $§ 306$ (West 2004) ("Noncompliance with this part by a nonparty to the marriage does not invalidate the marriage.").

${ }^{76}$ See 2 Op. Cal. Att'y Gen. 532, 533 (1943) ("The question as to the validity of a marriage is a judicial one for the courts to determine.").

77 See Lockyer, 95 P.3d at 497 ("Family Code section 300 clearly limits marriage in California to marriage between a man and a woman and flatly prohibits persons of the same sex from lawfully marrying in California .....).

${ }^{78}$ Indeed, the Bush Administration was so concerned that it directed the Social Security Administration to refuse to perform name changes based on California marriage licenses issued to same-sex couples. See Original Petition for Writ of Mandate, Prohibition, Certiorari and/or Other Appropriate Relief at 17 n.4, Lockyer, 95 P.3d 459 (No. S122923) (discussing a February 23, 2004 letter from the Social Security Administration to the California Department of Health Services asking the DHS to review marriage licenses submitted to the SSA as evidence of name change compliance with state law regarding valid marriages (on file with author)). Moreover, the California Supreme Court itself cited this doubt as justification for its decision to invalidate the 4000 same-sex marriage licenses that had already been issued. Lockyer, 95 P.3d at 497 ("[I] would not be prudent or wise to leave the validity of these marriages in limbo for what might be a substantial period of time given the potential confusion ... that such an uncertain status inevitably would entail.").

${ }^{79}$ Letter from Arnold Schwarzenegger, Governor, Cal., to Bill Lockyer, Attorney General, Cal. (Feb. 20, 2004), available at http://www.schwarzenegger.com/en/news/ uptotheminute/news_upto_en_lockyer.asp; see also Harriet Chiang \& John Wildermuth, Governor Demands End to Gay Marriage, Lockyer Told to Act Against S.F.'s Same-Sex Licenses, S.F. Chron., Feb. 21, 2004, at A1 (reporting the contents of the letter from Governor Schwarzenegger to Attorney General Lockyer). 
adequately enforced" and to bring suit to enjoin unlawful action. ${ }^{80}$ Lockyer, a Democrat and potential candidate for governor in 2006, initially rebuffed the Republican Governor, stating that he didn't take orders from the Governor ${ }^{81}$ and belittling the Governor's remarks as "a statement designed for consumption at the Republican convention." ${ }^{82}$ Moreover, he expressed some sympathy for same-sex couples. ${ }^{83}$ A week later, though, Lockyer changed course and filed suit in the California Supreme Court, seeking an order immediately directing San Francisco to stop issuing the licenses. ${ }^{84}$

On March 11, 2004, the California Supreme Court issued an interim order requiring the Mayor, County Recorder, and County Clerk to comply with the state statutes and cease issuing or registering marriage licenses to same-sex couples while the court considered the merits. ${ }^{85}$ By that time, more than 4000 licenses had been issued. ${ }^{86}$

${ }^{80}$ CAL. CONST. art. V, $\$ 13$.

${ }^{81}$ Rachel Gordon, Newsom Invites Governor To See Gay Rites; He Dismisses Fears SameSex Marriages Will Trigger Violence, S.F. CHRON., Feb. 24, 2004, at A1.

${ }^{82}$ Nanette Asimov, Lockyer Rejects Halt to Nuptials, He Dismisses Governor's Demand as a Political Ploy, S.F. Chron., Feb. 22, 2004, at A1. A similar situation occurred in New York. After the Mayor of New Paltz began marrying same-sex couples in late February 2004, Republican Governor George Pataki asked the Democratic Attorney General Elliot Spitzer to bring suit to enjoin the Mayor, but the Attorney General refused, indicating his support for same-sex marriage. Marc Santora \& Thomas Crampton, Same-Sex Weddings in Upstate Village Test New York Law, N.Y. TIMES, Feb. 28, 2004, at A1.

${ }^{83}$ See Chiang \& Wildermuth, supra note 79, at A1 (reporting Lockyer's statement that he does not "personally support policies that give lesser legal rights and responsibilities to committed same-sex couples").

${ }^{84}$ Lockyer, 95 P.3d at 466. Two days before the Attorney General filed suit, a group of San Francisco residents opposed to same-sex marriage also filed suit in the Supreme Court asking for similar relief. Id. at 466-67. In a similar vein, New York Attorney General Spitzer, though he did not file suit to stop New Paltz's actions, soon issued an opinion that New York statutory law forbade same-sex marriage and urged local officials to obey the law until courts adjudicated its constitutionality. See Marc Santora, Spitzer's Opinion Mixed on Status of Gay Marriage, N.Y. TIMES, Mar. 4, 2004, at A1 ("Until the courts ruled, [Spitzer] said, same-sex couples could not be legally married [in New York].").

${ }^{85}$ Lockyer, 95 P.3d at 467.

${ }^{86}$ Press Release, Office of the Mayor, City \& County of San Francisco, Mayor Newsom's Statement Regarding California Supreme Court Ruling on Same-Sex Marriage (Aug. 12, 2004), available at http://www.ci.sf.ca.us/site/mayor_page.asp?id=26838; Dean E. Murphy, San Francisco Married 4,037 Same-Sex Pairs From 46 States, N.Y. TIMES, Mar. 18, 2004, at A26. 


\section{Oregon}

The events in Multnomah County, Oregon (the county in which the City of Portland is located) followed a similar pattern. The county is governed by a five-member board of commissioners. In late January 2004, gay-rights activists had several meetings with the Chairwoman, Diane Linn, and two of the Commissioners, Serena Cruz and Lisa Naito, to discuss the Massachusetts judicial decision and how it might be applied in Oregon. ${ }^{87}$ Cruz, in turn, contacted a fourth Commissioner, Maria Rojo de Steffey, who also voiced her support for samesex marriages. ${ }^{88}$ So as to avoid triggering the state's open meetings law, no more than two Commissioners were present at any meeting or discussion. $^{89}$ Moreover, to ensure secrecy, the four Commissioners agreed to exclude Commissioner Lonnie Roberts, who opposed samesex marriage, from their discussions. ${ }^{90}$ Cautiously supportive of the activists' call for the recognition of same-sex marriage, the Commissioners asked the County Attorney for a legal opinion. ${ }^{91}$

In mid-February, just days after San Francisco began issuing marriage licenses, the County Attorney privately informed three of the Commissioners that, in her view, the Oregon Constitution does not permit the county to deny marriage licenses to same-sex couples. ${ }^{92}$ One of the three, Commissioner Naito, decided to ask for a second opinion from a private lawyer. On March 1, the County Attorney told the Chairwoman that her formal opinion was ready and that, while the outside lawyer had yet to finish drafting his opinion, his conclusion regarding the constitutionality of same-sex marriages was the same.

Under Oregon law, both the duty to issue marriage licenses and the duty to record marriage certificates are entrusted to the county

${ }^{87}$ David Austin et al., The Marriage Brokers, OREGOnIAN, Mar. 7, 2004, at A1, available at http://www.oregonlive.com/special/gaymarriage/index.ssf?/special/oregonian/ gaymarriage/040307_brokers.html.

${ }^{88} I d$.

${ }^{89}$ Id.; see also OR. REV. STAT. § 192.630(2) (2003) (prohibiting a quorum of any governing body from meeting "in private for the purpose of deciding on or deliberating toward a decision on any matter," except as expressly authorized by statute); MULTNOMAH COUNTY, OR., CHARTER \$ 3.30, available at http://www.co.multnomah.or.us/ counsel/charter.shtml\#_toc93316437 (providing that a majority of the five-member board of commissioners constitutes a quorum).

${ }^{90}$ Austin et al., supra note 87, at A1.

${ }^{91} I d$.

${ }_{92} I d$. 
clerks. $^{93}$ In nonchartered counties, the county clerk must be elected, ${ }^{94}$ but the Oregon Constitution expressly empowers chartered counties to provide for their own organization. ${ }^{95}$ Multnomah County, a chartered county, has assigned the duty of issuing marriage licenses to the county records office, whose head is appointed by-and may be removed at will by-the chairperson of the board of commissioners. ${ }^{96}$ On March 2, Chairwoman Linn, acting on the County Attorney's opinion, instructed the records office to begin preparations for the issuance of marriage licenses to same-sex couples. ${ }^{97}$ Not surprisingly, the county records office began issuing licenses to same-sex couples the next day.

As in San Francisco, the reaction from other local and state leaders was swift. The excluded Commissioner, Roberts, understandably assailed the "clandestine decision." 98 Governor Ted Kulongoski, a Democrat, initially struck a more conciliatory tone and asked Attorney General Hardy Myers, also a Democrat, to examine the legality of same-sex marriages. ${ }^{99}$ On March 12, Myers issued his opinion that,

${ }^{93}$ See OR. REV. STAT. § 106.077(1) (2003) (issuance of marriage certificates); id. § $106.180(1)$ (recordation of marriage certificates).

${ }^{94}$ OR. CONST. art. VI, § 6; OR. REV. STAT. § 204.005(2) (2003).

${ }^{95}$ OR. CONST. art. VI, $\$ 10$ ("A county charter shall prescribe the organization of the county government and shall provide directly, or by its authority, for the number, election or appointment, qualifications, tenure, compensation, powers and duties of such officers as the county deems necessary.").

${ }^{96}$ See Multnomah COUnTy, OR., CODE $\$ 7.001(\mathrm{~F})$ (2005), available at http://www2.co.multnomah.or.us/counsel/code/chapter7.htm\#_toc109463257 (assigning marriage license issuance and registration to the department of county management); Multnomah COUNTy, OR., Charter $\S 6.10(3)$, available at http://www.co.multnomah.or.us/counsel/charter.shtml\#_toc93316456 (providing that the chairperson "[s] hall have sole authority to appoint, order, direct and discharge administrative officers and employees of the county, except for the personal staff, employees or agents of elective county offices," and that "[a]ppointment of department heads shall be subject to consent of a majority of the board of commissioners"); Multnomah COUNTY, OR., CHARTER $§ 6.10(1)$ (providing that the chairperson is the "chief executive" of the county).

${ }^{97}$ Laura Gunderson, County Will License Gay Nuptials, OREGONIAN, Mar. 3, 2004, at A1 [hereinafter Gunderson, County Will License]. In response to public criticism regarding the secretive process, the County Commissioners belatedly scheduled a series of public meetings in late March regarding the issue. David Austin, County Sets Public Hearings, OREgOnIAN, Mar. 18, 2004, at A11.

${ }_{98}$ Gunderson, County Will License, supra note 97, at A1. Governor Ted Kulongoski likewise denounced the Commissioners' secret process as "unacceptable." Laura Gunderson, Gay Marriage Debate; More Same-Sex Couples Wait in Line to Get Their Marriage Licenses, OREGONIAN, Mar. 4, 2004, at A1 [hereinafter Gunderson, Gay Marriage Debate].

${ }_{99}$ Gunderson, Gay Marriage Debate, supra note 98, at A1; see also Statement from Attorney General Hardy Myers Regarding Same-Sex Marriages (Mar. 3, 2004), 
somewhat surprisingly, agreed with Multnomah County's position regarding the constitutionality of same-sex marriages. ${ }^{100}$ Though the Governor did not dispute Myers's conclusion, he announced that the state marriage statute should be obeyed until the Oregon Supreme Court-which he described as the only body in the state that could give a "definitive ruling"-could decide the statute's constitutionality. ${ }^{101}$ To that end, the Governor instructed all state agencies to abide by the statutory requirements. ${ }^{102}$

As in California, however, the Governor had few mechanisms available to actually take control of the situation. Though he is nominally the chief executive of the state and empowered to "take care" that the laws be faithfully executed, ${ }^{103}$ he does not have the authority to remove either the chairperson or any county administrative official. As a result, it was little surprise that Multnomah County defied the Governor's instruction and continued to issue licenses to same-sex couples. $^{104}$

The sole mechanism by which the governor could directly influence the issuance and recordation of marriages was through the director of human services, who is a gubernatorial appointee and who is removable at will by the governor. ${ }^{105}$ The director, in turn, appoints

\footnotetext{
http://www.doj.state.or.us/releases/rel030304b.htm.

${ }^{100}$ See Letter from Hardy Myers, Att'y Gen., Or., to Ted Kulongoski, Governor, Or. 11 (Mar. 12, 2004), http://www.doj.state.or.us/pdfs/AG_samesexopinion.pdf ("[T] he Oregon Supreme Court likely would conclude that withholding from same-sex couples the legal rights, benefits and obligations that-under current law-are automatically granted to married couples of the opposite sex likely violates ... the Oregon Constitution ....”). The Legislative Counsel to the Oregon Legislature also agreed that the prohibition on same-sex marriages was unconstitutional under the Oregon Constitution. See Letter from Gregory A. Chaimov, Legislative Counsel, Or., to Kate Brown, Senator, Or. 1 (Mar. 8, 2004) (on file with author) (stating that the Oregon Constitution "requires the state to grant a same-sex couple a license to marry on the same terms as a couple of the opposite sex").

${ }^{101}$ Press Release, Office of the Governor, Statement of Governor Ted Kulongoski (Mar. 12, 2004) (on file with author).

${ }^{102}$ See Press Release, Office of the Governor, Statements of Governor Ted Kulongoski and Attorney General Hardy Myers (Mar. 15, 2004) (on file with author) ("Pending a decision by the Oregon Supreme Court, and in accord with the Attorney General's advice, I have directed all state agencies to adhere to current state statutes, which do not recognize same-sex marriages.”).

${ }^{103}$ OR. CONST. art. V, $\S \S 1,10$.

${ }^{104}$ In fact, on April 1, the Multnomah County Commissioners adopted Resolution 04-039, which endorsed Chairwoman Linn's decision. Patrick O'Neill, Public Process; Same Result, OREgONIAN, Apr. 2, 2004, available at http://www.oregonlive.com/ special/gaymarriage/index.ssf?/special/oregonian/gaymarriage/040402_vote.html.

${ }^{105}$ OR. REV. STAT. $\$ 409.100$ (2) (2003). The Oregon Senate must approve the ap-
} 
the state registrar, who has the statutory duty of registering valid marriage certificates submitted by the county clerks. ${ }^{106}$ Like Governor Schwarzenegger, Governor Kulongoski instructed the State Registrar to refuse to register marriages of same-sex couples, ${ }^{107}$ and, pursuant to that instruction, the Registrar segregated the licenses received from Multnomah County, identified those that had been issued to same-sex couples, and refused to register them. ${ }^{108}$ Once again, though, this limited power was not sufficient to forestall the crisis because of doubts regarding the legal significance of the nonregistration of the marriages. ${ }^{109}$

As the Governor had anticipated and called for, the controversy could only be resolved definitively by the courts. Once again, though, the Governor could not initiate the judicial proceedings. Like California, Oregon entrusts the power to sue to enforce state law to the attorney general, who is also an elected official. ${ }^{110}$ Fortunately for Governor Kulongoski, the Attorney General was also a Democrat with no apparent desire to snub the Governor, and, hence, the two state officials appeared to work in concert. The Attorney General did not file suit to enjoin Multnomah County's action, but he negotiated with the Multnomah County Attorney and other interested outside parties to arrange for a single consolidated, expedited suit to adjudicate the legality of the county's actions.

pointment but may not interfere in the governor's removal of the director. Id.

${ }^{106} I d . \S 432.020$; see also id. $\$ 432.405$ (1) (providing that each marriage must be filed and registered if it complies with rules adopted by the registrar).

${ }^{107}$ See Press Release, Office of the Governor, supra note 102 (directing "all state agencies to adhere to current state statutes, which [did] not recognize same-sex marriages"). The Attorney General subsequently sent letters to all county clerks informing them of the Governor's instruction and advising them that the State Registrar would not record same-sex marriages. See, e.g., Letter from Hardy Myers, Att'y Gen., to Julia Woods, County Clerk, Baker County (Mar. 18, 2004) (on file with author) (stating that "any such records already... received by the Center for Health Statistics ... will be returned to the issuing counties" and that "[i]f any county tenders additional same-sex marriage records to [the Center], these records will not be accepted").

${ }^{108}$ In addition, the State Registrar sent letters to the same-sex couples advising them that their marriages had not been recorded and that the marriage certificates had been returned to the County Clerk. See, e.g., Letter from Jennifer A. Woodward, State Registrar, Or., to Donna Potter \& Pamela Moen (Mar. 23, 2004) (on file with author) ("The marriage license issued by Multnomah County to you does not constitute a 'marriage record' as described in ORS 432.405.").

109 Oregon attaches more significance to recordation by the state registrar than by the county clerk. See OR. REv. STAT. $\$ 106.180(2)$ (2003) (providing that the county's record of marriage is not a vital record under Oregon law). Nevertheless, no provision clearly establishes that a marriage not registered by the state is not a valid marriage.

${ }^{110} I d . \$ \$ 180.020, .060(1)(\mathrm{D})(2003)$. 
While those negotiations were ongoing, the Governor's inability to control the situation became even more apparent. On March 16, Benton County announced that it would also issue marriage licenses to same-sex couples starting March $24 .{ }^{111}$ Fearing that other counties might follow suit, the Attorney General asked Benton County to rescind its decision and threatened legal action if Benton County refused to comply. ${ }^{112}$ Two days before it was to begin issuing licenses, Benton County announced that it would await a judicial decision, but—remarkably—it also announced that it would no longer issue any marriage licenses, even to heterosexual couples, to avoid unlawful discrimination. ${ }^{113}$

On March 19th, the Attorney General, county, and outside parties reached an agreement for a speedy judicial resolution of the controversy. ${ }^{114}$ Pursuant to the agreement, same-sex couples filed suit in Multnomah County Circuit Court, challenging the constitutionality of the Oregon marriage statute. As agreed, the case was heard on an expedited schedule, and, on April 20, 2004, the trial court issued its decision. ${ }^{115}$ The court ruled that the Oregon marriage statute violated the Oregon Constitution, and it ordered the State Registrar to record same-sex marriages that had been licensed and solemnized. ${ }^{116}$ The

${ }^{111}$ Mark Larabee \& Ashbel S. Green, Benton Approves Gay Marriage, OREGONIAN, Mar. 17, 2004, at A1, available at http://www.oregonlive.com/special/gaymarriage/ index.ssf?/special/oregonian/gaymarriage/040317_benton.html.

${ }^{112}$ See Letter from Hardy Myers, Attorney General, Or., to Kevin Mayne, Deputy County Counsel, Benton County, Or. 1 (Mar. 18, 2004) (on file with author) ("We understand that Benton County intends to begin issuing same-sex marriage licenses on March 24, 200[4]. To protect the state's interests, we are compelled to consider bringing appropriate legal action.”).

See Mark Larabee \& Jeff Mapes, Benton Stops All Marriage Licensing, OREGOnIAN, Mar. 23, 2004, at A1, available at http://www.oregonlive.com/special/gaymarriage/ index.ssf?/special/oregonian/gaymarriage/040323_benton.html (discussing the County Commission vote to suspend marriage licensing "until the Oregon Supreme Court rules on whether gay marriages in Oregon are legal"). Benton County began issuing marriage licenses to heterosexual couples in late August 2004, but only after a court ordered it to do so. See Kyle Odegard, Judge Tells Benton County to Issue Marriage Licenses, CORVAllis GAZETTE-Times (Oregon), Aug. 26, 2004, available at http://www.gazettetimes.com/articles/2004/08/26/news/top_story/thu01.txt (noting the court's ruling that, by not issuing the licenses, "the county failed its duty to provide citizens with a service").

${ }^{114}$ See Press Release, Office of the Attorney General (Mar. 19, 2004), available at http://www.doj.state.or.us/releases/pdf/release_032204.pdf (detailing the agreedupon "procedure and schedule for accelerated consideration of constitutional challenges to Oregon statutes relating to marriage for same-sex couples").

${ }^{115}$ Li v. State, No. 0403-03057, 2004 WL 1258167 (Or. Cir. Ct. Apr. 20, 2004), rev'd, 110 P.3d 91, 102 (2005).

${ }^{116} I d$. at $* 6-7,9$. 
court further ordered the legislature to adopt a new statute to provide equal benefits and privileges to same-sex couples. ${ }^{117}$ Startlingly, however, the court also ordered Multnomah County to stop issuing marriage licenses to same-sex couples. ${ }^{118}$ By that time, almost 3000 samesex marriage licenses had been issued. ${ }^{119}$ An appeal to the Oregon Supreme Court quickly ensued. ${ }^{120}$

In sum, as the events in California and Oregon demonstrated, it was the fragmentation of the state executive branch that made the controversy over same-sex marriage licenses possible. With no authority as a practical matter to stop the events in San Francisco and Multnomah County, the Governors in the respective states were left with no recourse but to ask their Attorneys General to seek judicial resolution of the localities' conduct. Moreover, it would be up to the courts, not the Governors, to decide whether the county officials could act the way they did.

\section{JUDICIAL EXCLUSIVITY}

When confronted with a situation in which an executive official has refused to enforce a statute that the official believes to be unconstitutional, courts typically hold that the official's action is illegal. The predominant view is that the executive lacks authority to refuse to enforce a statute because, as a constitutional matter, the interpretation and enforcement of the constitution is exclusively for the judiciary. This Part assesses whether the separation of powers or other policy concerns require vesting the interpretation and enforcement of the constitution solely in the judiciary. As I show, there is no persuasive justification for a system of judicial exclusivity even with regard to executive review by local officials.

${ }^{117}$ See $i d$. at $* 8$ ("It is incumbent upon the legislature to evaluate the substantive rights afforded to married couples and to provide similar access to same-sex domestic partners. The court will allow the legislature to come up with a remedy consistent with this judicial holding ....").

${ }^{118} I d$. at $* 10$.

${ }^{119}$ Li v. State, 110 P.3d 91, 94 (2005).

${ }^{120}$ As discussed in Part IV.A, the Oregon Supreme Court subsequently reversed the decision. See id. at 102 (holding that state-licensed marriage in Oregon is limited to opposite-sex couples). 


\section{A. The Judicial Exclusivity Model}

The authority of executive officials to refuse to enforce statutes that they believe to be unconstitutional has often come before the courts. Most recently, in Lockyer v. City and County of San Francisco, the California Supreme Court ruled that the San Francisco officials who issued marriage licenses to same-sex couples had acted unlawfully. ${ }^{121}$ The court's holding was both blunt and broad: "When ... a duly enacted statute imposes a ministerial duty upon an executive official to follow the dictates of the statute in performing a mandated act, the official generally has no authority to disregard the statutory mandate based on the official's own determination that the statute is unconstitutional." 122 In elaborating on the basis for this rule, the court rooted its decision in the California Constitution's separation of powers. ${ }^{123}$ As the court saw it, the power to interpret and enforce the constitution was a uniquely judicial power. ${ }^{124}$

The Lockyer court is not alone in its embrace of judicial exclusivity. Other courts have adopted this approach to executive review. Moreover, though there are some differences among the courts' analyses, these other courts have likewise embraced a formal, separation-ofpowers-infused division of authority among the three branches of government with regard to the enforcement of constitutional norms.

All of the various arguments for a regime of judicial exclusivity fail, however. The fundamental defect with this approach is that the separation of powers does not impose "an absolute or rigid division of functions." ${ }^{125}$ The modern administrative state entails the delegation

12195 P.3d 459, 499 (Cal. 2004).

${ }^{122} I d$. at $463-64$.

123 See id. at 463 ("[T] he legislative power is the power to enact statutes, the executive power is the power to execute or enforce statutes, and the judicial power is the power to interpret statutes and to determine their constitutionality."); see also CAL. CONST. art. III, $\$ 3$ ("The powers of state government are legislative, executive, and judicial. Persons charged with the exercise of one power may not exercise either of the others except as permitted by this Constitution.").

${ }^{124}$ See Lockyer, 95 P.3d at 480 ("[U]nder California law, the determination whether a statute is unconstitutional and need not be obeyed is an exercise of judicial power ....").

${ }^{125}$ Id. at 463; see also State v. Gilfillan, 998 P.2d 1069, 1076 (Ariz. Ct. App. 2000) (holding that separation of powers “does not require a 'hermetic sealing off' of the branches of government one from another"); Commonwealth v. Gonsalves, 739 N.E.2d 1100, 1105 (Mass. 2000) ("[S] eparation of powers does not require three watertight compartments within the government." (internal quotation marks omitted) (quoting 
of broad rulemaking and adjudicatory authority to executive officials. ${ }^{126}$ And even the "pure" administration of statutes necessarily requires the executive to interpret the law. ${ }^{127}$ For this reason, attempts to wall off certain functions, like rulemaking or adjudication, as exclusively legislative or judicial in character have proven to be jurisprudentially incoherent. Acknowledging the inevitability of some overlap in functions, the modern approach to the separation of powers has focused on whether the mixing of functions somehow threatens or usurps the authority of one of the other branches of government. As this Subpart shows, executive review does not pose that sort of constitutional danger.

\section{Executive Review as an Attack on the Judiciary}

The bulk of the decisions condemning executive review do so on the ground that executive nonenforcement of statutory mandates somehow usurps the role of the judiciary in interpreting and enforcing the constitution. The Missouri Supreme Court, in ruling that an executive official must discharge her statutory duties, declared that "[t]he power to declare a statute enacted by the law-making department of the state unconstitutional is intrusted only to the judicial department of the state government [and] is not only judicial in its character, but ... is of the highest judicial character." ${ }^{128}$ Similarly, the Minnesota Supreme Court stated tersely that "[o]fficials acting ministerially are not clothed with judicial authority."

Opinions of the Justices to the Senate, 363 N.E.2d 652, 659 (Mass. 1977))).

${ }^{126}$ See McHugh v. Santa Monica Rent Control Bd., 777 P.2d 91, 110 (Cal. 1989) (holding that an administrative agency may adjudicate claims for restitution without usurping judicial power); Wright v. KECH-TV, 707 P.2d 1232, 1236 (Or. 1985) (holding that the delegation of adjudicative authority to a state agency does not violate separation of powers); see also GRODIN, supra note 74, at 85 (noting that California courts "accept[ed] delegations of [legislative] power so long as they were accompanied by some standards to guide administrative discretion and permit judicial review").

${ }^{127}$ See Easterbrook, supra note 3, at 905 (arguing that, although the President implements the law, "[b] efore he can implement he must interpret"); see also, e.g., Nebeker v. Utah State Tax Comm'n, 34 P.3d 180, 185 (Utah 2001) (requiring a prospective litigant to present her constitutional challenge to the tax commission because the commission may modify its rules to avoid the alleged constitutional violation).

${ }^{128}$ State ex rel. Mo. \& N. Ark. R.R. v. Johnston, 137 S.W. 595, 598 (Mo. 1911); see also State ex rel. Chi., Rock Island \& Pac. Ry. v. Becker, 41 S.W.2d 188, 190 (Mo. 1931) (citing with approval the Johnston rule).

${ }^{129}$ State ex rel. Clinton Falls Nursery Co. v. Steele County Bd. of Comm'rs, 232 N.W. 737, 738 (Minn. 1930); see also Bd. of Supervisors v. Dep't of Revenue, 263 N.W.2d 227, 233 (Iowa 1978) (citing with approval the Steele County rule). For examples of similar decisions from other jurisdictions, see Florida ex rel. Atl. Coast Line R.R. 
This view no doubt resonates with many, but it erroneously conflates executive nonenforcement with a usurpation of the judiciary's power of judicial review. Many executive acts can be said to be adjudicatory in nature. When a clerk processes an application for admission to a public university or a claim for welfare benefits, the clerk can be said to be "adjudicating" or deciding the applicant's rights. The critical question is whether executive adjudications made on constitutional grounds differ in some material way from the routine case. That is, is there a difference between a clerk's refusal to issue a license because she believes (erroneously) that the statute does not entitle the applicant to the license and a clerk's refusal to issue a license because she believes (erroneously) that the constitution forbids such action? Is the latter case any more of a usurpation of the judicial function than the former, which no one contests as interfering with the judiciary's authority to say what the law is? For several reasons, I think not.

First, when an executive official refuses to discharge some duty on constitutional grounds, she is not purporting to determine the constitutionality of the statute in a way that binds other officials, her successor in office, or herself in a later case. Unlike the case with respect to a definitive constitutional ruling from the state's supreme court, which applies to all government officials and which binds lower courts and even the supreme court itself to some extent in later cases, a lone official's interpretation of the constitution has no impact beyond those under her control with respect to the exact matter under consideration. Even a constitutional determination by a governor has no binding effect upon her successor, who is free to reject her predecessor's view of the constitution.

Second, and more important, an executive official's constitutionally based ruling does not supplant the judiciary's ability to resolve the constitutional issue or threaten the judiciary's status. Consider the Oregon Land Use Board of Appeals (LUBA), an administrative

v. Bd. of Equalizers, 94 So. 681, 683 (Fla. 1922) ("The right to declare an act unconstitutional is purely a judicial power, and cannot be exercised by the officers of the executive department ....”); State ex rel. New Orleans Canal \& Banking Co. v. Heard, 18 So. 746, 752 (La. 1895) ("Laws are presumed to be, and must be treated and acted upon by subordinate executive functionaries as, constitutional and legal, until their unconstitutionality or illegality has been judicially established . . .."); Smyth v. Titcomb, 31 Me. 272, 285 (1850) (ruling that an executive official "is not authorized[] or required to adjudicate the law"); State ex rel. Davidson v. Sedillo, 275 P. 765, 765 (N.M. 1929) (holding that ministerial officials must obey a law until it is declared unconstitutional by the judiciary); State ex rel. Cruce v. Cease, 114 P. 251, 252 (Okla. 1911) (holding that executive officials have no power to assume a law is unconstitutional and fail to enforce the law). 
agency that is empowered to engage in executive review with regard to land use determinations by local governments, such as zoning ordinances and variances from such ordinances. ${ }^{130}$ By statute, LUBA may set aside a local land use decision where the local government's decision is unconstitutional. ${ }^{131}$ Because LUBA's decisions are subject to judicial review by the Oregon Court of Appeals, there can be no claim that executive review denies the judiciary the ability to decide the meaning of the constitution. ${ }^{132}$ Perhaps LUBA's existence reduces the number of land use cases reaching the courts, but that hardly seems like a serious ground for concern. If anything, LUBA's existence assists the judiciary by reducing its caseload and providing for a standardized channel through which land use cases are presented for judicial review. In light of this, it is understandable that the Oregon Supreme Court properly rejected a separation-of-powers challenge to LUBA's existence. ${ }^{133}$ And, if it is acceptable for a legislature to require an administrative agency to consider takings challenges, there should be no separation-of-powers problem with other officials' consideration of constitutional claims.

\section{Executive Review as an Attack on the Legislature}

Less common but still prevalent, several courts have condemned executive review on the ground that it disrespects the legislature, which (so it goes) should be presumed to have acted constitutionally. ${ }^{134}$ The Illinois Supreme Court put this objection in the strongest form and personally admonished the executive official who refused to perform his statutory duty:

You assumed the responsibility of declaring the law unconstitutional, and at once determined to disregard it, to set up your own judgment as superior to the expressed will of the legislature, asserting, in fact, an entire independence thereof. This is the first case in our judicial history, in

${ }^{130}$ See OR. REV. STAT. $\$ 197.810$ (2003) (establishing LUBA).

131 OR. REV. STAT. \$ 197.835(8), (9) (a) (E) (2003).

132 See OR. REV. STAT. \$197.850(1) (2003) ("Any party to a proceeding before the Land Use Board of Appeals . . . may seek judicial review of a final order ... .."); $c f$. Crowell v. Benson, 285 U.S. 22, 49-50 (1932) (upholding the delegation of adjudicative authority to a federal executive agency where the statute provided for judicial review of agency determinations of questions of law).

133 See Wright v. KECH-TV, 707 P.2d 1232, 1236 (Or. 1985) ("[T] he doctrine of separation of powers does not prevent the exercise of adjudicatory functions by LUBA.").

${ }^{134}$ See State ex rel. New Orleans Canal \& Banking Co. v. Heard, 18 So. 746, 751 (La. 1895) (listing cases subscribing to this rationale for denying executive review). 
which a ministerial officer has taken upon himself the responsibility of nullifying an act of the legislature for the better collection of the public revenue-of arresting its operation-of disobeying its behests, and placing his own judgment above legislative authority expressed in the form of law. $^{135}$

It is true that executive review licenses an executive official to act in ways perhaps at odds with what the legislature intended, but so what? No one suggests that the legislature's intent must be honored when doing so would violate the constitution; were that not the case, judicial review itself would be problematic. Moreover, no one disputes the right of executive officials to disregard a statutory duty declared unconstitutional by the courts; ${ }^{136}$ nor, for that matter, does anyone contest the right of statutory officials to refuse to perform some duty because they believe (erroneously) that the statute does not require such duty. Thus, for opponents of executive review, the task is to identify how executive review undermines legislative authority more than judicial review or executive administration of the laws in ways that are at odds with what the legislature intended because the executive misread the statute. I am dubious that such a showing is possible.

More importantly, even if executive review somehow undermines legislative authority in some qualitatively distinct way, it would not justify reading the constitutional separation of powers to forbid such executive action. Whatever threat executive review poses to the legislature can be addressed by the legislature itself. The legislature can limit or eliminate the discretionary authority of nonconstitutional executive officials, thereby barring executive review by the affected officials. In fact, the judicial exclusivity model cannot be squared with the conception of legislative supremacy upon which it hypothetically rests because it limits legislative authority; even if the legislature were to authorize executive review (as the Oregon legislature did with LUBA), the judicial exclusivity model would condemn such measures.

A variant of this argument against executive review focuses less on its alleged slight to the legislature and more on the structural imbalance that may be caused by allowing executive review. According to this version of the argument, a governor's refusal to enforce a statute

${ }^{135}$ People ex rel. Att'y Gen. v. Salomon, 54 Ill. 39, 45-46 (1870).

${ }^{136}$ See, e.g., Lockyer v. City \& County of San Francisco, 95 P.3d 459, 487-88 (Cal. 2004) (suggesting that executive officials may disregard a statute when "a governing decision previously has found an identical statute unconstitutional" or "the invalidity of the statute is so patent or clearly established that no reasonable official could believe [it] is constitutional"). 
is equivalent to an absolute veto because, unlike the qualified legislative veto possessed by governors, a governor's nonenforcement decision is not subject to legislative review or override. Indeed, the one court to reject executive review at the state level on this ground went so far as to hypothesize that a sharp governor would sign a questionable statute into law, thereby avoiding the possibility of a legislative override of her constitutionally inspired veto, but then refuse to enforce the provisions she deemed unconstitutional. ${ }^{137}$

Were executive review structurally akin to an absolute veto, there would be cause for alarm. After all, state constitutions scrupulously ensure that gubernatorial vetoes are subject to legislative reconsideration and override. The professed similarity of executive review to an absolute veto, however, is overstated. ${ }^{138}$ As noted above, executive review does not entail the invalidation of the statute; the law remains "on the books" for the current governor (if she changes her mind or discovers a nonproblematic situation in which to execute the law) or a subsequent governor to enforce. ${ }^{139}$ Moreover, while a veto may be exercised for any reason, executive review licenses nonenforcement only when the executive concludes that the statute violates the constitution, not when the executive merely dislikes or finds it politically in-

${ }^{137}$ State ex rel. Atl. Coast Line R.R. Co. v. Bd. of Equalizers, 94 So. 681, 683 (Fla. 1922) ("In fact, the Governor need not return to the Legislature without his approval any bill that he believes to be unconstitutional. He may sign it, or let it become a law without his signature, and then refuse to enforce it ...."); see also Johnsen, supra note 3 , at 32 (hypothesizing that "routine" nonenforcement would lead the President to eschew veto in favor of nonenforcement). A more limited variant of this argument views executive review as equivalent to a line item veto, which the U.S. Constitution does not provide the President and many state constitutions fail to give to their governors. See Clinton v. City of New York, 524 U.S. 417, 448-49 (1998) (invalidating a statutorily conferred line item veto); see also Miller, supra note 3, at 397 (opposing executive review because it is equivalent to a line item veto). Indeed, the lone federal court to expressly consider the President's power of executive review rejected it on this ground. See Lear Siegler, Inc. v. Lehman, 842 F.2d 1102, 1124 (9th Cir. 1988) ("The 'line item veto' does not exist in the federal Constitution, and the executive branch cannot bring a de facto 'line item veto' into existence by promulgating orders to suspend parts of statutes which the President has signed into law."). Of course, many state constitutions provide governors with a line item veto. Hence, even if executive review were legally equivalent to a line item veto, that would not demonstrate the former's unconstitutionality. In any event, this argument fails for the same reason that the broader claim about executive review's equivalence to an absolute veto fails. See infra text accompanying notes $138-40$.

${ }^{138}$ See Johnsen, supra note 3, at 15 ("A presidential refusal to enforce a statutory provision on constitutional grounds does not effect a veto ....”).

${ }^{139}$ Id. at 32; Lawson \& Moore, supra note 1, at 1306. 
convenient to execute the law. ${ }^{140}$ Thus, executive review poses a far less significant intrusion into the legislature's prerogatives than does an absolute veto.

True, executive review is potentially more powerful than a veto in the sense that each governor over time gets to decide for herself whether to enforce the statute, while the latter may be exercised only by the particular governor in office at the time that the legislature enacts the bill. But it is hard to see how this difference cuts against executive review. In fact, it would seem to cut in favor of executive review since, as Judge Frank Easterbrook has observed, no official may "consent to violate the Constitution, or bind his successor to do so." ${ }^{141}$ Thus, for example, President John Adams, a Federalist, signed into law the Sedition Act, which made it a federal crime to criticize the President (but not the Vice President, who happened to be Thomas Jefferson, a Republican). ${ }^{142}$ The statute expired by operation of law on the day that President Jefferson took office but expressly provided that prosecutions for conduct occurring before its lapse could continue. $^{143}$ Upon becoming President, Thomas Jefferson pardoned those previously convicted under the Act and, more importantly for present purposes, directed that ongoing prosecutions cease because of his belief, embraced by the Supreme Court over a century later, that the act's limitation on political speech violated the First Amendment. ${ }^{144}$ Surely, Jefferson was not constitutionally bound to put aside his constitutional concerns about the Act and continue the prosecutions because Adams had signed the bill into law. Indeed, while opponents of executive review worry about intrusions on the legislature's prerogatives, supporters of it may cogently respond that forbidding executive review unduly interferes with the democratic process by requiring a popularly elected official to enforce laws that she believes to be (and potentially campaigned upon as) unconstitutional.

Of equal importance, even if executive review were equivalent to

${ }^{140}$ Lawson \& Moore, supra note 1, at 1306.

${ }^{141}$ Easterbrook, supra note 3, at 917.

${ }^{142}$ See Sedition Act of 1798, ch. 74, § 2, 1 Stat. 596, 596 (expired Mar. 3, 1801) (criminalizing the making of "false, scandalous and malicious" writings against, inter alia, the President).

${ }^{143} I d . \S 4$.

${ }^{144}$ See Letter from Thomas Jefferson to Abigail Adams (July 22, 1804), in 11 THE WRITINGS OF THOMAS JEFFERSON 42, 43-44 (Andrew A. Lipscomb \& Albert Ellery Bergh eds., 1904) (stating that Jefferson considered the Act "to be a nullity, as absolute and as palpable as if Congress had ordered us to fall down and worship a golden image"); see also Strauss, supra note 3, at 121 (discussing Jefferson's actions). 
an absolute veto in some formal sense, that would not be true in a functional sense because legislatures do have ways of "overriding" executive nonenforcement decisions. Most notably, they can pressure the governor politically, through hearings and press conferences, to execute the law. More confrontationally, they can use their budgetary authority and control of the legislative process to induce executive compliance by refusing to promote the governor's favored programs and policies. ${ }^{145}$ And, of course, most confrontationally, they can impeach the governor or state official. Moreover-and here's the rubin most states, the legislative vote necessary to impeach and remove an executive official is exactly the same as or even less stringent than that required for overriding the governor's legislative veto. ${ }^{146}$ Of course,

${ }^{145}$ Johnsen, supra note 3, at 39; Strauss, supra note 3, at 109.

146 Exactly half of the states follow the federal model, requiring a two-thirds vote of each house to override a gubernatorial veto, a majority vote of the lower house to impeach the governor, and a two-thirds vote of the upper house to convict and remove the governor. ARIZ. CONST. art. V, $\$ 7$, art. VIII, pt. 2, §§ 1, 2; CAL. CONST. art. IV, §§ 10, 18; Colo. Const. art. IV, $\$ 11$, art. XIII, $\$ 1$; ConN. Const. art. 4, $\$ 15$, art. 9, $\$ \S 1$, 2; GA. Const. art. III, § V, para. XIII(d), art. III, § VII, paras. I, II, art. V, § II, para. IV; HAw. Const. art. III, $\S \S 17,19$; IDAho Const. art. IV, $\S 10$, art. V, $\$ 4$; IOWA Const. art. III, $\S \S 16,19$; KAN. Const. art. 2, $\S 14$, 27; LA. CONST. art. III, $\S 18(\mathrm{C})$, art. X, $\S$ 24(b); ME. Const. art. IV, pt. 1, § 8, art. IV, pt. 2, § 7, art. IV, pt. 3, § 2; MiCH. COnST. art. IV, $\S 33$, art. XI, $\S 7$; MINN. Const. art. IV, $\$ 23$, art. VIII, $\S 1$; NEV. Const. art. 4, $\$$ 35, art. 7, § 1; N.J. Const. art. V, § I, para. 14(b) (3), art. VII, § III, para. 2; N.M. ConsT. art. IV, $\S \S 22,35$; N.D. Const. art. V, $\S 9$, art. XI, $\S \S 8,9$; OKLA. ConsT. art. VI, $\S 11$, art. VIII, $\$$ 3, 4; PA. Const. art. IV, § 15, art. VI, \$§ 4, 5; S.D. ConsT. art. IV, § 4, art. XVI, $\S \S 1$, 2; TEX. Const. art. 4, $\S 14$, art. 15, $\S 1$, 3; VA. Const. art. IV, $\S 17$, art. V, $\S$ 6(b) (ii); WASH. CONST. art. III, $\S 12$, art. V, $\$ 1$; WIS. CONST. art. V, $\$ 10$, art. VII, $\$ 1$; WYO. CONST. art. $3, \S 17$, art. 4 , $\S 8$. In eight states, the requirements are the same for both impeachment and the override of a veto. Seven of these require a two-thirds vote of each house either to override a veto or to impeach and convict the governor. FLA. CONST. art. III, $\S \S 8(\mathrm{c}), 17$; MISS. CONST. art. 4, $\S \S 49,52,72$; MonT. COnST. art. V, $\S$ 13, art. VI, § 10; S.C. CONST. art. IV, § 21, art. XV, §§ 1, 2; UTAH CONST. art. VI, $\$ \$ 17$, 18, art. VII, $\S 8$; VT. CONST. ch. II, $\$ \S 11,57,58$; see also AlASKA Const. art. 2, $\S 16,20$ (requiring a two-thirds vote of both houses, sitting as one body, to override a veto, except for the veto-override of a tax or appropriations bill, which requires a three-fourths vote, and requiring a two-thirds vote of both houses to impeach and convict the governor). Meanwhile, one state, Alabama, requires a majority vote of both houses either to override a veto or to impeach and convict the governor. ALA. CONST. art. V, $§ 125$, art. VII, § 173. Lastly, two states make it much easier to impeach and convict the governor than to override her veto, requiring only a majority vote of both houses for the former but a two-thirds vote of each for the latter. MASs. CONST. pt. 2, ch. I, § II, art. VIII, pt. 2, ch. I, § III, art. VI, pt. 2, ch. I, § I, art. II; N.H. CoNST. pt. 2, arts. 17, 38, 44.

In a minority of states, the legislative vote required to override the governor's veto is less than that required to impeach and convict the governor. Of these, four states require a majority in both houses to override the veto, a majority of the lower house to impeach, but a two-thirds vote of the state senators to convict. ARK. CONST. art. 6, § 15, art. 15, § 2; Ky. CONST. $\S \S 66,67,88$; TENN. Const. art. III, § 18, art. V, §§ 1, 2; W. VA. 
impeachment is formally limited to situations involving malfeasance or breach of the public trust, but that plausibly encompasses situations in which an executive official refuses to execute a law for constitutional reasons rejected by the legislature. ${ }^{147}$ Thus, as a practical matter, executive review is not immune from legislative review or control and, therefore, does not pose the sort of structural imbalance that would justify reading the separation of powers in the rigid, formalistic way embraced by these courts.

CONST. art. IV, $\S 9$, art. VII, $\S 14$. Four states require a three-fifths vote of each house to override the governor's veto, only a majority of the lower house to impeach, but a two-thirds vote of the state senate to convict. ILL. CONST. art. IV, \$§ 9(c), 14; MD. CONST. art. II, § 17 (a), art. III, § 26; N.C. CONST. art. II, § 22(1), art. IV, § 4; OHIO CONST. art. 2, $\S \S 16,23$. Two states require a three-fifths vote of each house to override a veto but a two-thirds vote of each house to impeach and convict the governor. DEL. CONST. art. III, $\S 18$, art. VI, § 1; R.I. CONST. art. IX, § 14, art. XI, §§ 1, 2. One state, Indiana, requires a majority vote of each house to override a veto but a two-thirds vote of each house to impeach and convict the governor. IND. CONST. art. $5, \S$ 14(a) (2) (B), art. 6, § 7. Lastly in this group, three states provide that the lower house may impeach the governor but involve the state judiciary in the impeachment trial. Mo. CONST. art. III, $\S 32$, art. VII, $\S 2$ (requiring a two-thirds vote of each house to override a veto and a majority of the lower house to impeach, and providing for conviction by a seven-member special commission elected by the senate, with five votes required to convict); NEB. CONST. art. III, $\S 17$, art. IV, $\S 15$ (requiring a three-fifths vote of each house to override a veto, a majority of the lower house to impeach, and a twothirds vote of the justices of the supreme court to convict); N.Y. CONST. art. IV, $\S 7$, art. VI, $§ 24$ (requiring a two-thirds vote of each house to override a veto, a majority of the assembly to impeach, and a two-thirds vote of the combined senate and state court of appeals to convict).

Only the Oregon legislature lacks the power to impeach a sitting state official. OR. CONST. art. V, $\S 15 \mathrm{~b}$ (requiring a two-thirds vote of both houses to override a veto, but containing no provision for impeachment).

${ }^{147}$ See Lawson \& Moore, supra note 1, at 1310 ("Congress could express its own, contrary constitutional judgment through an impeachment proceeding."). Indeed, the first impeachment of a U.S. President-that of Andrew Johnson-was based on his refusal to enforce the Tenure in Office Act, ch. 154, 14 Stat. 430 (1867), and, though President Johnson survived by one vote in the Senate, his survival surely did not demonstrate the impropriety of the underlying theory that, in certain circumstances at least, nonenforcement may be proper grounds for impeachment. See Strauss, supra note 3, at 109-10 (noting that, irrespective of legal limitation, Congress has "raw power" to impeach the President for any reason it wants); see also 116 CONG. REC. 9, 11913 (1970) (statement of Rep. Gerald R. Ford) ("[A]n impeachable offense is whatever a majority of the House of Representatives considers [it] to be at a given moment in history; conviction results from whatever offense or offenses two-thirds of the other body considers to be sufficiently serious to require removal of the accused from office."). 


\section{Rejecting Categorical Formalisms}

Perhaps because of these conceptual flaws, the judicial exclusivity model has collapsed under its own weight. There are numerous instances in which courts have allowed executive officials to disregard statutory mandates on constitutional grounds. ${ }^{148}$ One prominent exception involves instances in which executive officials, charged with the issuance of bonds, letting of public contracts, or disbursement of public funds, have refused to perform those duties on constitutional grounds. ${ }^{149}$ The California Supreme Court rationalized this limited power of executive review on the ground that it would "ensure that a mechanism was available for obtaining a timely judicial determination of the validity of the bond issue, contract, or public expenditure" and guarantee that the official did not incur personal liability for administering a statute subsequently found unconstitutional. ${ }^{150}$ Likewise, other courts have treated this exception as necessary to protect executive officials from incurring personal liability for unconstitutional conduct. ${ }^{151}$

Of course, these pragmatic rationales for the exception swallow the rule itself. If the purpose of allowing public officials to disregard a statutory mandate is to precipitate a quick judicial decision, that rationale would apply to all statutory mandates, not just those involving public finances. ${ }^{152}$ Indeed, the Washington Supreme Court endorsed a general right to engage in executive review on this ground. ${ }^{153}$ So too

${ }^{148}$ See Easterbrook, supra note 3, at 914-15 (collecting instances in which U.S. Presidents have refused to execute congressional laws).

${ }^{149}$ See Lockyer v. City \& County of San Francisco, 95 P.3d 459, 482 (Cal. 2004) (citing, inter alia, Cal. Hous. Fin. Agency v. Elliott, 551 P.2d 1193 (Cal. 1976), which sanctioned such an action by administrative officials).

${ }^{150} I d$. at 483 . The instant case, the court quickly interjected, did not involve a public bond or contract, nor did it present a situation in which the relevant local officials faced personal liability for enforcing the marriage statute. Id. at 483-84; see also id. at 505 (Kennard, J., concurring and dissenting) (concluding that San Francisco officials did not face any potential personal liability for enforcing statute).

${ }^{151}$ See, e.g., Bd. of Supervisors v. Dep't of Revenue, 263 N.W.2d 227, 233 (Iowa 1998) (acknowledging an exception where the official "would be personally liable for implementing a statute later held invalid"); State ex rel. Pierce v. Slusher, 248 P. 358, 359-60 (Or. 1926) (acknowledging the right of a sheriff to refuse to perform the statutory duty of serving income tax warrants if she believes the tax to be unconstitutional because she would be personally liable for any sum collected if the tax were unconstitutional).

${ }^{152}$ See Easterbrook, supra note 3, at 929 (noting that presidential review facilitates judicial review by precipitating a court case).

${ }^{153}$ Hindman v. Boyd, 84 P. 609, 612 (Wash. 1906). 
with the personal liability rationale. While there are state and federal provisions that limit an executive official's personal liability for discharging her public duties, those provisions typically apply only if the official's actions are "reasonable" or made in "good faith."

Another exception involves instances in which a governing judicial decision had previously struck down an identical statute or where the statute's invalidity was "so patent or clearly established that no reasonable official could believe the statute is constitutional." ${ }^{155}$ Even more broadly, some courts acknowledge an exception where the constitutional concern animating the official's action is one of "general public interest." 156

One might question how these exceptions do not also swallow the rule against executive review, but more importantly, the courts' acknowledgment of these (and other) exceptions to the "general rule" undermines their own formalist claim that the interpretation and enforcement of the state constitution is a uniquely judicial function. Obviously, an official's refusal to issue a bond or release public funds is an executive act, and it remains an executive act even if the basis for such refusal is a concern about the constitutionality of the underlying statutory mandate or fear of personal liability. Likewise, whether a statute is patently unconstitutional is a judgment call, and, according to the courts, it is a judgment that an executive official is entitled to make in the performance of her concededly executive duties. Requiring that the unconstitutionality be "patent" only narrows the circumstances in which an executive may ignore a statutory mandate; it does

${ }^{154}$ See, e.g., CAL. GOV’T CODE $\$ \S 820.6,825$ (West 1995) (providing qualified immunity and qualified reimbursement, respectively, for violations of state law); Harlow v. Fitzgerald, 457 U.S. 800, 818 (1982) (recognizing qualified immunity for a violation of federal law).

${ }^{155}$ Lockyer, 95 P.3d at 487; see also id. at 501 (Moreno, J., concurring) (advocating an exception for instances when a statute violates a "clearly established" constitutional right); $i d$. at 503 (Kennard, J., concurring and dissenting) (advocating an exception for instances when a statute's unconstitutionality "is obvious beyond dispute in light of unambiguous constitutional language or controlling judicial decisions"). The court concluded that California's ban on same-sex marriages, even if unconstitutional (an issue on which the court did not pass), was not so patently unconstitutional as to fit into this "narrow" exception. Id. at 488 (majority opinion); see also id. at 503-04 (Kennard, J., concurring and dissenting) (agreeing with the court's analysis on this point).

${ }_{156}$ Dep't of State Highways v. Baker, 290 N.W. 257, 261 (N.D. 1940); State ex rel. State Bridge Comm'n v. Griffith, 25 N.E.2d 847, 849 (Ohio 1940); see also Linn County, 263 N.W.2d at 233 (noting an exception where the "subject matter of the challenged statute is of particularly major public importance”); Toombs v. Sharkey, 106 So. 273, 277 (Miss. 1925) (allowing executive review by officials charged with the public fisc where there is a "serious question" of the statute's constitutionality). 
not eliminate it entirely as the judicial exclusivity model would require. $^{157}$

Lastly, even courts that have condemned the authority of executive officials to refuse to perform a clear statutory duty on constitutional grounds have acknowledged the right of officials to consult the constitution in determining what the statute in fact requires. ${ }^{158}$ Strictly speaking, this limited interpretive authority does not implicate a strong version of executive review-the official is refusing to perform some task, not because the constitution forbids it, but because the statute as read in light of the constitution does not require it. Nevertheless, the acknowledgment of interpretive authority in these circumstances demonstrates that the constitutional separation of powers does not assign the interpretation of the constitution exclusively to the judiciary. After all, it is hard to see any difference between an official's refusal to perform some task because she thinks that the constitution forbids it versus a refusal to perform that task because she thinks that the statute interpreted in light of the constitution does not require it. ${ }^{159}$

In short, the separation of powers does not mandate a rigid, formalist compartmentalization of governmental powers that rules out executive review. ${ }^{160}$ When an executive official refuses to perform some statutory task because of constitutional concerns, that decision is not inherently nonexecutive in nature, nor is it an invasion of some function reserved exclusively to the judiciary or legislature.

${ }^{157}$ Justice Moreno was prepared to acknowledge additional exceptions to the Court's rule, such as when the challenged statute "governs matters integral to a locality's limited power of self-governance" or when the statute threatens irreparable harm "to individuals to which the local government agency has some protective obligation." Lockyer, 95 P.3d at 501-02 (Moreno, J., concurring). Justice Kennard, in turn, was prepared to acknowledge exceptions for when nonenforcement "is necessary to preserve the status quo and to prevent irreparable harm pending judicial determination," when enforcement "could put the public official at risk for substantial personal liability," or when nonenforcement "is the only practical means to obtain a judicial determination of the constitutional question." Id. at 503 (Kennard, J., concurring and dissenting).

${ }^{158}$ See, e.g., Dore v. Tugwell, 84 So. 2d 199, 202 n.5 (La. 1955) (distinguishing an executive official's contention that a statute is unconstitutional, which is an impermissible ground for nonenforcement, from her argument that one possible interpretation of the statute is unconstitutional, which is a permissible ground for enforcing the statute in way that comports with such a construction).

${ }^{159}$ See State ex rel. Test v. Steinwedel, 180 N.E. 865, 867 (Ind. 1932) (approving executive review because it is no different in principle from allowing an official to refuse to perform a duty that she believes the statute does not require).

${ }^{160}$ See, e.g., Lockyer, 95 P.3d at 510 (Werdegar, J., concurring and dissenting) (criticizing the majority's arrogation of constitutional interpretation to the judiciary). 


\section{B. A More Modest Separation of Powers Theory: The Policy Arguments}

If the separation of powers does not mandate a rigid compartmentalization of powers, perhaps it still nevertheless precludes executive officials from refusing to perform statutorily mandated duties on constitutional grounds. Pursuing this line of argument, several courts have offered policy arguments against executive review. Though they differ in detail, all of the arguments share the view that executive officials are institutionally ill-equipped to engage in constitutional interpretation, at least in comparison to judges.

The broadest and bluntest version of this argument against executive constitutional interpretation highlights the fact that most executive officials are not attorneys and therefore have no expertise regarding constitutional interpretation. ${ }^{161}$ Though no court has been so candid to say so expressly, the thrust of the claim seems to be that legal training is indispensable to the task of interpreting and enforcing constitutional norms. This is an identity-based argument: executive review is impermissible because of who the executive officials are.

This identity-based attack on executive review, however, grossly overstates both the relevance of a legal education to constitutional interpretation and its implications for executive review. As an initial matter, it is not clear why a legal education, much less membership in the bar, is essential to constitutional interpretation. As Christopher Eisgruber has argued, constitutionalism as practiced in America presumes that all citizens are able to engage in the political and moral reasoning that animates our constitutional discourse. ${ }^{162}$ The contrary view - that only lawyers can understand the constitution-cannot be squared with our commitment to self-government. Moreover, even if lawyers alone possessed some special ability to fathom constitutional intricacies, that would not justify a regime of judicial exclusivity; rather, it would point to an interpretive paradigm that valued the con-

161 See, e.g., id. at 490 (majority opinion) (“[M]ost local officials have no legal training and thus lack the relevant expertise to make constitutional determinations.”). The court conceded that all citizens are free to form their own views of the constitution, but it declared that local executive officials were not authorized to impose their own view of the constitution on others. Id. Evidently, only courts are entitled to impose their own view of the constitution on the citizenry!

${ }^{162}$ See Christopher L. Eisgruber, Constitutional Self-Government 57-58 (2001) ("We cannot say that . . . the people are too dense to make their own judgments about fundamental issues of political justice. In effect, democracy requires us to assume a parity of basic moral judgment: all mentally competent adults are equally possessed of the capacity to tell right from wrong."). 
stitutional opinions of all lawyers (or at least constitutional law professors!), not just judges. And, since many state and local executive officials are lawyers, executive review would be constitutionally permissible. Finally on this point, according such a privileged interpretive position to lawyers would not necessarily condemn executive review by nonlawyers; so long as nonlawyer public officials consulted with an attorney and followed her instructions (as the officials in Multnomah County did), that would presumably put to rest any concern about lay officials acting on (putatively) uninformed constitutional views. ${ }^{163}$

More narrowly, some courts condemn executive review not because of the identity of executive officials, but because of the process that those officials use in engaging in executive review. Specifically, they emphasize that, in contrast to judicial proceedings, executive officials may engage in constitutional interpretation without providing any opportunity for those affected by the decision to be heard. ${ }^{164}$

At the outset, it is important to identify exactly what is meant by this argument. The courts cannot be suggesting that constitutional due process (e.g., the Fourteenth Amendment to the U.S. Constitution) precludes executive review. Due process protections are triggered only when the government deprives an individual of "life, liberty, or property." 165 While the latter two concepts have undergone some expansion in the past three decades, ${ }^{166}$ it would be stretching matters much too far to say that all governmental decisions implicate a property or liberty interest. ${ }^{167}$ That would constitutionalize every govern-

163 See, e.g., Wiles v. Williams, 133 S.W. 1, 6-7 (Mo. 1910) (acknowledging the right of the State Treasurer to refuse compliance with a statute where the Attorney General had advised the Treasurer that the statute was unconstitutional); Dep't of State Highways v. Baker, 290 N.W. 257, 262 (N.D. 1940) (same with respect to the State Auditor).

${ }^{164}$ See, e.g., Lockyer, 95 P.3d at 491 (noting that local officials "made their own constitutional determination without conducting any such evidentiary hearing"). The California Supreme Court's professed concern about due process had a tinny ring to it. Besides enjoining the issuance of marriage licenses to same-sex couples in the future, the court also invalidated the 4000 marriage licenses already issued by San Francisco, even though the court had denied requests by some of the now-married couples to intervene to defend the validity of their marriages. Id. at 496; see also id. at 509-10 (Werdegar, J., concurring and dissenting) (criticizing the majority's invalidation of existing marriage licenses without permitting intervention by the affected couples).

${ }^{165}$ U.S. CONST. amends. V, XIV.

${ }^{166}$ See, e.g., Goldberg v. Kelly, 397 U.S. 254, 261 (1970) (holding that a property interest exists in Aid to Families with Dependent Children welfare payments).

${ }^{167}$ See, e.g., Bd. of Regents of State Colls. v. Roth, 408 U.S. 564, 569 (1972) ("The requirements of procedural due process apply only to the deprivation of interests encompassed by the Fourteenth Amendment's protection of liberty and property."). For example, while all San Francisco residents might be interested in the same-sex mar- 
mental decision, which the U.S. Supreme Court has been unwilling to do and which would bring government to a halt as a practical matter. $^{168}$

Perhaps the point is only that constitutional decisions made without notice and an opportunity to be heard are suspect, but even this more modest, nonconstitutional formulation is mistaken. That courts would trumpet the value of judicial-style hearings is no surprise, but it is wrong to assume that the procedures employed by judges are also suitable for and should be demanded of executive and legislative officials. Hans Linde has pointed out the errors of applying the judicial model of due process to the legislative process. ${ }^{169}$ For similar reasons, it is also inappropriate to apply it across the board to the executive process. Unlike judges, who are expected to perform their task in a neutral, unrushed, unbiased fashion, executive officials are expected to do the public's bidding and to do so sometimes in a quick, energetic fashion. ${ }^{170}$ Modern executive officials would quickly become ineffective and be the subject of unending public ridicule if they convened a public hearing in advance of each and every decision. There is no gainsaying the value of hearings-indeed, it is for that reason that both federal and state administrative procedure acts require hearings of various sorts in a variety of settings ${ }^{171}$ - but not every decision warrants such formal process. The key question is whether, outside the realm of constitutional due process, there are decisions in which the executive should be required to afford interested individuals some sort of formal process.

This is not the time to lay out a complete theory explaining what types of decisions deserve formal court-like procedures, but certainly

\footnotetext{
riage issue, it would be nonsense to claim that each resident had a liberty or property interest in the enforcement of the marriage statutes as written.

${ }^{168}$ See, e.g., Am. Mfrs. Mut. Ins. Co. v. Sullivan, 526 U.S. 40, 60-61 (1999) (holding that there is no property interest in workers compensation payments pending a determination of the reasonableness of medical care).

${ }^{169}$ See Hans A. Linde, Due Process of Lawmaking, 55 NEB. L. REv. 197, 222-35 (1976) (arguing that requiring legislators to follow the analytical model of judicial review of the rationality of legislation, which includes a consideration of the goals of the legislation and the potential means to achieve those goals, ignores the political realities of creating legislation and would render legislative bodies ineffective).

${ }^{170}$ Cf. Ass'n of Nat'l Advertisers v. FTC, 627 F.2d 1151, 1168-69 (D.C. Cir. 1979) (refusing to require the same level of neutrality required of judges for agency officials engaging in rulemaking because of the need for expertise and expedition).

${ }_{171}$ See, e.g., Administrative Procedure Act, 5 U.S.C. $\$ 554$ (2000) (setting forth hearing requirements for agency adjudications where an agency's organic statute requires a hearing "on the record").
} 
not all decisions involving constitutional considerations need be preceded by such process. Take, for example, the time-honored distinction between rulemaking and adjudication. As a matter of both constitutional and administrative law, policymakers engaged in rulemaking need not provide trial-like procedures. ${ }^{172}$ As Justice Holmes explained, in lieu of court-like hearings, we rely upon the political process to prevent arbitrary action in the rulemaking context. ${ }^{173}$ We presume that the electoral process sensitizes public officials to the competing viewpoints of the citizenry, and, though some may scorn that presumption, it is not entirely unfounded. Today's elected officials and even some appointed officials are bombarded every day with letters and calls advocating some course of action. As a result, though it might be nice for an executive official to conduct a hearing before promulgating a rule that is based on constitutional considerations, it is not essential that she do so in order to develop a feel for the competing arguments.

This last consideration points to the final, fatal flaw in the due process argument. Even if there were some occasions in which a constitutionally based administrative or executive decision warranted a formal, judicial-style hearing, that would not justify reading the constitution to preclude executive review. Rather, outside the realm of decisions for which constitutional due process requires some sort of hearing, it is up to the legislature to balance the competing considerations of fairness and efficiency and decide under what circumstances executive officials should conduct a hearing and of what sort. Perhaps constitutionally based decisions deserve such process, but there are many administrative decisions that have an equally, if not more, substantial impact on individuals that do not involve constitutional considerations and for which there is no formal process required (e.g., scholarship decisions at public universities). Weighing the value of

${ }^{172}$ See 5 U.S.C. $\$ 553$ (c) (requiring notice and comment, but not an oral hearing, for informal rulemaking by federal agencies); Bi-Metallic Inv. Co. v. State Bd. of Equalization, 239 U.S. 441, 445 (1915) (rejecting a due process challenge to the city's refusal to hold an oral hearing regarding city-wide property revaluation). Only in the rare instance in which Congress requires the agency to conduct rulemaking "on the record after opportunity for an agency hearing" are trial-like procedures required, 5 U.S.C. \$ 553(c); United States v. Fla. E. Coast R.R., 410 U.S. 224, 237-38 (1973), and even then agencies may sometimes proceed on the basis of written submissions. See 5 U.S.C. $\$ 556(\mathrm{~d})$ (allowing written submissions "when a party will not be prejudiced thereby").

${ }^{173}$ See Bi-Metallic, 239 U.S. at 445 (noting that, in the rulemaking context, "[the people's] rights are protected in the only way that they can be in a complex society, by their power, immediate or remote, over those who make the rule"). 
hearings against their cost in time and money in the myriad circumstances in which a constitutional claim could be raised seems a task much better suited for the scalpel of the legislative process than the machete of a court's constitutional mandate.

None of this is to say that the absence of such process is irrelevant to the legality of executive review. As I argue below, the legislature's refusal to provide for a formal process may be probative of its intent that the official not consider and act upon constitutional claims. ${ }^{174}$ Nor is this to suggest that the California Supreme Court was wrong to be troubled by the process used by San Francisco. The Mayor's failure to conduct a hearing at which city residents could air their views was disappointing. The actions in Multnomah County, Oregon, in which the County Commissioners conspired to avoid the requirements of the state's open meetings law and excluded one of their members, are deserving of opprobrium. These failures, however, are not of a constitutional magnitude, and they do not justify reading the respective state constitutions to bar executive review.

There is another process-based objection to executive review, though it attacks executive review from the opposite direction from the due process argument. While the due process argument decried executive review because executive officials are allegedly too uninformed or biased to consider constitutional claims, this objection worries that they are too disinterested to be reliable constitutional interpreters. As the Minnesota Supreme Court worried, executive officials "would be raising questions affecting the rights of third persons while they themselves would have no direct interest in the question and could not in any event be made responsible."175

It really takes some chutzpah for a court to contend that disinterest-something courts typically trumpet about the judicial process-is somehow disabling when it comes to constitutional review. ${ }^{176}$ Indeed, these courts have universally failed to explain why such disinterest is disabling when it comes to executive officials engaging in executive review but not when it comes to judges performing judicial review.

${ }^{174}$ See infra text accompanying notes 243-45.

175 State ex rel. Clinton Falls Nursery Co. v. Steele County Bd. of Comm'rs, 232 N.W. 737, 738 (Minn. 1930); see also State ex rel. Chicago, Rock Island \& Pac. Ry. v. Becker, 41 S.W.2d 188, 191 (Mo. 1931) (discussing officials' lack of direct personal interest); Thoreson v. State Bd. of Exam'rs, 57 P. 175, 178 (Utah 1899) (stating that "a very dangerous precedent" would be set if officials lacking personal interest were allowed to refuse to perform a duty based on their interpretation of its constitutionality).

${ }^{176}$ See also EISGRUBER, supra note 162, at 57-59 (arguing that the disinterestedness of courts makes judicial review legitimate). 
Its internal inconsistency aside, this objection mistakes the nature of executive action. Most officials care deeply about the duties they perform, and that is particularly true when an executive official refuses to perform some duty on constitutional grounds. ${ }^{177}$ Because of the likely outcry, litigation, and other potential sanctions that may accompany such action, it is most unlikely that officials who engage in executive review will do so lightly. The stereotypical image of bureaucratic lethargy and indifference is particularly unwarranted in these circumstances. Moreover, when an official refuses to perform some duty, it is likely that the official views herself as a representative of sorts for the private individuals who would be adversely affected by a faithful enforcement of the statute. ${ }^{178}$ Indeed, Mayor Newsom consciously held himself out as the defender of the rights of same-sex couples. That process of self-identification with the private parties further ensures that the official is taking the matter seriously and not simply refusing to do her statutory duty for the sport of it.

This concern about bureaucratic indifference, while not justifying a regime of judicial exclusivity, may point to a different doctrinal response to executive review, though. One might take the position that an executive official does not have judicial standing to commence a legal action to challenge the constitutionality of a statute the official is charged with enforcing because the official has nothing at stake in the fight. In fact, as a historical matter, virtually all of the early decisions condemning executive review arose in mandamus actions in which a private party brought suit to compel the official to perform her statutory duty. In rejecting the official's constitutional defense, the courts often conflated the issue of the officer's right not to enforce the statute with the issue of her standing to raise the constitutional question as a defense in the judicial action. ${ }^{179}$ In light of this, it may be more

${ }^{177}$ See State ex rel. Test v. Steinwedel, 180 N.E. 865, 867 (Ind. 1932) (refusing to assume that officials "will dishonestly or without reason rely upon unconstitutionality as an excuse for nonperformance of a duty").

${ }^{178}$ Cf. State ex rel. McCurdy v. Tappan, 29 Wis. 664, 686 (1872) (approving executive review by the Town Clerk because the Clerk acted as a representative of the town in refusing to enforce a statute to the town's detriment).

179 See, e.g., State ex rel. Atl. Coast Line R.R. v. State Bd. of Equalizers, 94 So. 681, 684 (Fla. 1922) (noting that officials do not have "any material interest, personal or pecuniary, that would be injuriously affected or prejudiced by the act in question, entitling them to question its constitutionality"); Steele County, 232 N.W. at 738 (noting that an executive official has no personal or property right at stake in the enforcement of a statute); State ex rel. City of Wolf Point v. McFarlan, 252 P. 805, 808 (Mont. 1927) (" $[\mathrm{O}]$ ne who is neither injured nor jeopardized by the operation of a statute cannot challenge its constitutionality.”); Att'y Gen. v. Taubenheimer, 164 N.Y.S. 904, 905 
faithful to those decisions to read them as establishing the more narrow principle that an officer does not have judicial standing to contest a statute's constitutionality. Indeed, modern decisions discussing executive review have typically viewed the issue as one involving standing. ${ }^{180}$ In fact, the Florida Supreme Court has expressly distinguished between instances in which the official commences a suit to invalidate a statute (which is impermissible) and instances in which the official fails to take statutorily mandated action and asserts the statute's unconstitutionality as a defense (which is permissible) - a rule of law drawn expressly from the court's application of its standing doctrine. ${ }^{181}$

Much to the chagrin of opponents of executive review, reconceiving these decisions as focusing on the judicial standing of executive officials harmonizes the decisions with a system of executive review. One could very easily take the position that an official has the authority to refuse to execute a statute she believes unconstitutional, then hold that the official does not have standing to seek judicial invalidation of the act. This view rejects judicial exclusivity but acknowledges that traditional statutory and constitutional limits on the judicial power may prevent officials from seeking judicial invalidation of a statute they are charged to enforce. Indeed, the Wisconsin Supreme Court embraced this precise rule. ${ }^{182}$ For present purposes, I take no

(App. Div. 1917) (holding that the Town Supervisor did not have standing to challenge the use of city taxes); Capito v. Topping, 64 S.E. 845, 846 (W. Va. 1909) (noting that the defense of unconstitutionality may only be raised by officials "having a personal interest or right, which the unconstitutional act invades or violates"); Riverton Valley Drainage Dist. v. Bd. of County Comm'rs, 74 P.2d 871, 873 (Wyo. 1937) (holding that a county treasurer does not have standing to challenge the constitutionality of the use of county taxes because he was not injured by the operation of a statute).

${ }^{180}$ See, e.g., Denver Urban Renewal Auth. v. Byrne, 618 P.2d 1374, 1379 (Colo. 1980) (" $[\mathrm{P}]$ olitical subdivisions of the state, and the officers thereof, lack standing to challenge the constitutionality of a state statute directing the performance of their duties."); Bd. of Supervisors v. Dep't of Revenue, 263 N.W.2d 227, 234 (Iowa 1978) (noting that the county auditor and assessor would not incur personal liability by complying with a statute and that they did not have a "sufficient personal interest or stake" to satisfy "traditional tests of constitutional standing").

${ }^{181}$ Compare Fuchs v. Robbins, 818 So. 2d 460, 463 (Fla. 2002) (concluding that an officer does not have standing to initiate a lawsuit challenging the constitutionality of a statute), with Dep't of Educ. v. Lewis, 416 So. 2d 455, 458 (Fla. 1982) (acknowledging the standing of an officer to challenge the constitutionality of a statute when the officer is a defendant).

${ }^{182}$ See City of Kenosha v. State, 151 N.W.2d 36, 43 (Wis. 1967) (holding that the city lacked standing to challenge the constitutionality of a statute, but that the city could refuse to enforce the statute as a way of precipitating judicial review). 
position on the standing of executive officials to commence suit, ${ }^{183}$ but the availability of this middle option demonstrates that much of the early judicial hostility to executive review may have been misinterpreted by opponents of executive review.

\section{C. "Confusion and Chaos"}

The final policy-based argument against executive review is perhaps the one shared most viscerally by many people. The prospect of myriad officials each adopting and acting on her own subjective view of the constitution runs counter to the orderly administration of laws most people prize. As the California Supreme Court worried:

[T] here are thousands of elected and appointed public officials in California's 58 counties charged with the ministerial duty of enforcing thousands of state statutes. If each official were empowered to decide whether or not to carry out each ministerial act based upon the official's own personal judgment of the constitutionality of an underlying statute, the enforcement of statutes would become haphazard, leading to confusion and chaos and thwarting the uniform statewide treatment that state statutes generally are intended to provide. ${ }^{184}$

Moreover, as the court warned, this chaos and confusion would necessarily last for a "considerable" time because the courts would be unable to respond quickly to determine the validity of the officials' constitutional views. ${ }^{185}$ More hysterically, the Illinois Supreme Court warned that allowing executive review would entail "an end . . . to civil government." ${ }^{186}$

No doubt this argument resonates with many-after all, the specter of each county clerk deciding for herself who is constitutionally entitled to marry in her county does not seem attractive to anyone but the most diehard localists. ${ }^{187}$ The critical question, however, is

${ }^{183}$ But see Atl. Coast Line, 94 So. at 686 (Whitfield, J., dissenting) (arguing that the governor and attorney general, at least, should be granted standing to bring an action to contest a statute's validity).

${ }^{184}$ Lockyer v. City \& County of San Francisco, 95 P.3d 459, 491 (Cal. 2004); see also $i d$. at 506 (Kennard, J., concurring and dissenting) (" $[\mathrm{C}]$ onfusion and chaos would ensue if local public officials in each of California's 58 counties could separately and independently decide not to enforce long-established laws with which they disagreed, based on idiosyncratic readings of broadly worded constitutional provisions."); Smyth v. Titcomb, 31 Me. 272, 287 (1850) (warning of the "ruinous" consequences of allowing executive review).

${ }^{185}$ Lockyer, 95 P.3d at 492.

${ }^{186}$ People ex rel. Att'y Gen. v. Salomon, 54 Ill. 39, 46 (1870).

${ }^{187}$ For a provocative argument that such decisions should be made at the local 
whether this concern about the lack of uniformity in the enforcement of state law justifies a constitutional prohibition on executive review. Contrary to the conventional wisdom, I argue that it does not. Moreover, let's take the argument in its strongest, least sympathetic context: executive review by local officials. If executive review is constitutionally permissible in that context, it follows a fortiori that it is constitutionally permissible when undertaken by state officials.

At the outset, it is important to draw a critical distinction between local officials' enforcement of state statutes and their administration of local ordinances. As to the latter, it seems implausible that the state constitution forbids cities or counties from allowing their public officials to refuse to enforce a local ordinance that the official believes to be unconstitutional. Consider, for example, a local ordinance that banned gay and lesbian individuals from using the city's public parks. Would it violate the state constitution for the city park director to refuse to enforce the law because of her belief that it violates the state constitution's equal protection clause? Surely not. The city council may deny her the discretionary authority to act in this way, but that is for the city council to decide. If the city council instead permitted such discretion in the enforcement of city ordinances, no one could object that the city council violated the state constitution in so doing. True, there would be a lack of uniformity in how different officials in different localities understood the state constitution, but that is not the lack of uniformity that troubles the courts or concerns most people. Such abstract disagreements exist daily-each citizen has a different view of the constitution. What concerns the courts is the nonuniform enforcement of state statutes of statewide applicability produced by such disagreement.

Okay, then, but what about local officials' enforcement of state law? Surely here the state constitution forbids executive review so as to ensure the uniform application of state law. But why? There is no constitutional requirement that the state legislature enact laws that produce the same public policy throughout the state. ${ }^{188}$ To the con-

level (though not by county clerks), see Richard C. Schragger, Cities as Constitutional Actors: The Case of Same-Sex Marriage, 21 J.L. \& POL. 147, 153-67 (2005). Interestingly, Arizona's Constitution forbids the state legislature from enacting local or special bills regarding divorce, but not bills regarding marriage. ARIZ. CONST. art. IV, pt. 2, § 19.

${ }^{188}$ Article IV, Section 16 of the California Constitution, which provides that "[a]ll laws of a general nature have uniform operation," is not to the contrary. As the California Supreme Court has made clear, the uniformity required is "uniformity in operation, not uniformity of result." Wholesale Tobacco Dealers v. Nat'l Candy \& Tobacco Co., 82 P.2d 3, 18 (Cal. 1938). And, uniformity in operation does not even mean geo- 
trary, it is acceptable for the legislature to provide benefits to or impose regulatory regimes on certain parts of the state, ${ }^{189}$ and, even more common, it is permissible for the legislature to delegate certain policy decisions to local officials, even if the legislature is aware that different officials will use the delegated authority in different ways. Viewed more broadly, then, the nonuniformity produced by executive review by local officials is not unique, nor is it cause for constitutional alarm.

Indeed, consider the following hypothetical: The legislature decides that the controversy over same-sex marriages is pointlessly dividing the state and that, instead of imposing a statewide rule about who may marry whom, it will empower each county clerk to decide who is entitled to marry in that clerk's county. Acting pursuant to this statutory delegation of authority, some county clerks authorize same-sex marriages. Moreover, further assume that the county clerks in these counties do so only because, as they state in their press releases, it is their firm conviction that the state constitution's equal protection clause mandates such recognition. Now, is this statute unconstitutional either on its face or as applied by the clerks?

The former suggestion-that the hypothetical statute is facially invalid-would be frivolous. The state legislature delegates authority of this sort all the time. ${ }^{190}$ Nor would the statute be unconstitutional as applied. ${ }^{191}$ The statute itself contemplates that there will be a lack of

graphic uniformity. Thus, courts have upheld legislation targeting only one county. See, e.g., White v. State, 105 Cal. Rptr. 2d 714, 718 (Cal. Ct. App. 2001) ("It is well settled that article IV, section 16 does not prohibit the Legislature from enacting statutes that are applicable solely to a particular county or local entity.").

189 See, e.g., People ex rel. Scearce v. Glenn County, 35 P. 302, 304 (Cal. 1893) (upholding the state law establishing Glenn County); White, 105 Cal. Rptr. 2d at 718-19 (upholding a special statute benefiting solely Orange County).

${ }^{190}$ See, e.g., CAL. GOV’T CODE $§ 23004$ (West 2003) (delegating various powers to counties); CAL. GOV'T CODE $\$ 27640$ (West 1988) (delegating power to the county board of supervisors to appoint county counsel); CAL. HARB. \& NAV. CODE $\S 4150$ (West 2001) (delegating power to the county board of supervisors to decide when to open towpaths); CAL. HARB. \& NAV. CODE $\$ 4160$ (delegating power to the county board of supervisors to adopt quarantine regulations).

${ }^{191}$ This hypothetical assumes that there is no constitutional provision forbidding same-sex marriages. Several states have such a constitutional provision. See, e.g., ARK. CONST. amend. 83, $§ 1$ ("Marriage consists only of the union of one man and one woman."); LA. CONST. art. XII, § 15 (refusing to recognize marriages not between "one man and one woman"); Miss. CONST. art. 14, § 263A ("Marriage may take place and may be valid under the laws of this state only between a man and a woman."). In those states, the clerks' actions would violate the constitutional prohibition on same-sex marriage but would not violate the separation of powers or any other constitutional provision. 
uniformity in the definition of marriage throughout the state. That such lack of uniformity is produced by the clerks' constitutional convictions rather than some other consideration (e.g., the clerks' desire to curry favor with their counties' gay and lesbian communities so as to build political support for the next election) is an immaterial distinction, and one that could not be enforced in practice in any event.

Okay, but the California statute regarding marriage does not provide the county clerks with this type of delegated discretion. That is quite right, as I discuss below, ${ }^{192}$ but that is also beside the point for present purposes. Recall that we are considering whether there is some constitutional objection to executive review of state law by local officials. Such review may be illegal because the statute enacted by the legislature does not permit such review, but that would be a statutory objection to the practice.

Lastly, to approve of the constitutionality of executive review by local officials, at least when licensed by the state legislature, is not to say that those officials may disregard state court rulings adjudicating the constitutional validity of the questioned statute. There is a difference between allowing executive review and permitting executive officials to refuse to enforce statutes that have been upheld by the courts (or enforcing statutes that have been invalidated by the judiciary). To put it in the academic vernacular: one can be in favor of executive review and also judicial supremacy. ${ }^{193}$

At the federal level, the seminal case is Cooper v. Aaron, in which the Supreme Court rejected the right of state officials to act in ways contrary to the judicial interpretation of the Constitution. ${ }^{194}$ Cooper, recall, involved Arkansas Governor Faubus's refusal to desegregate the Little Rock public schools because of his disagreement with the Court's decision in Brown v. Board of Education that the Equal Protection Clause forbade racial segregation. ${ }^{195}$ Responding to Governor Faubus's hateful insolence, the Supreme Court ruled that state officials, such as the governor, were bound by the Supreme Court's interpretation of the Constitution. The Court attributed this rule to Marbury v. Madison, ${ }^{196}$ which, according to the Court, "declared the basic principle that the federal judiciary is supreme in the exposition of the law of the Constitution, and that principle has ever since been re-

192 See infra Part IV.B.2.

${ }_{193}$ See, e.g., Easterbrook, supra note 3, at 926 (embracing both).

194358 U.S. 1, 19 (1958).

195347 U.S. 483 (1954).

${ }^{196} 5$ U.S. (1 Cranch) 137 (1803). 
spected by this Court and the Country as a permanent and indispensable feature of our constitutional system."197 Significantly, however, Cooper did not deny the power of state officials to enforce the Constitution, but rather only to disregard the Supreme Court's interpretation once made. ${ }^{198}$

Though Cooper involved the relationship between the federal courts and state officials, one might argue that, analogously, local officials should be allowed to act on their own views of the state constitution until the state supreme court decides the matter, at which point they are bound by the court's decision. For present purposes, I am agnostic on this point-whether something like the Cooper rule applies to the relationship between state courts and local officials in a given state is a question beyond this Article's scope ${ }^{199}$ —and I raise it only to demonstrate that local executive review does not necessarily entail chaos and confusion even in those situations in which the legislature allows local officials to consider constitutional claims. Combined with a commitment to judicial supremacy, local executive review would result in nonuniformity only until such time as the state supreme court resolved the question. ${ }^{200}$ And, if such temporary nonuniformity is

${ }^{197}$ Cooper, 358 U.S. at 18. As I and others have argued, Cooper misread Marbury, which said nothing about other officials, federal or state, being bound by the Court's interpretation. See, e.g., KRAMER, supra note 2, at 221 (arguing that Cooper "manufacture[d]" a new reading of Marbury); Norman R. Williams, The People's Constitution, 57 STAN. L. REV. 257, 273-76 (2004) (concurring with Kramer and further defending his reading of Marbury). That is a debate for a different day, however.

${ }^{198}$ It would not violate Cooper, for example, for a state to decide to issue marriage licenses to same-sex couples because, in its view, the Equal Protection Clause of the Fourteenth Amendment required it, at least until the U.S. Supreme Court weighed in on the issue.

${ }^{199}$ But see Lockyer v. City \& County of San Francisco, 95 P.3d 459, 511 (Cal. 2004) (Werdegar, J., concurring and dissenting) (arguing that local officials are bound by the California Supreme Court's decisions but may act upon their own views prior to the Court's ruling).

${ }^{200}$ The California Supreme Court was fearful that courts would not be able to intervene in a sufficiently timely manner. See id. at 492 ("[T] he confused state of affairs arising from diverse actions by a multiplicity of local officials frequently would continue for a considerable period of time, because [the court] could not order a public official to comply with the challenged statute until the court actually had determined that it was constitutional."). Yet, on this point, the court was much too pessimistic about the tools available to the courts to prevent nonuniformity. For example, lower courts could issue a stay or preliminary injunction requiring the official to execute the statute pending the completion of the litigation. Indeed, once the supreme court issued a stay in Lockyer-one month after San Francisco began issuing the licenses-the officials immediately complied. See News Release, Judicial Council of Cal., California Supreme Court Takes Action in Same-Sex Marriage Cases (Mar. 11, 2004), http://www.courtinfo.ca.gov/presscenter/newsreleases/NR15-04.HTM (announcing 
cause for concern, the legislature is in the best position to address it by statutorily precluding executive review in such instances or requiring expedited judicial review.

In sum, contrary to the prevailing orthodoxy, there is no general constitutional prohibition on executive review. In certain states, there may be unique constitutional provisions that expressly limit or forbid state executive review, ${ }^{201}$ but the enforcement of the constitution is not an exclusively judicial function, nor are there any compelling policy arguments for reading the separation of powers to forbid executive review. This does not mean that the actions of the San Francisco and Multnomah County officials were legal, only that they were not unconstitutional.

\section{EXECUTIVE REVIEW AS A CONSTITUTIONAL Right}

What about the opposite extreme of the constitutional spectrum? Perhaps the constitution protects the right of executive officials to engage in executive review and to refuse to enforce a statute that they believe to be unconstitutional. This argument shares one feature with the foregoing judicial exclusivity model: they both assume that the state constitution definitively resolves the interpretive authority of executive officials. While the judicial exclusivity model constitutionally bars officials from engaging in executive review even in circumstances in which the legislature authorizes it, this claim contends that the constitution authorizes executive review even in circumstances in which the legislature has prohibited it.

\section{A. The Oath Clauses}

Pressed to identify the source of this "right" to engage in executive review, executive officials typically point to their state constitution's oath clause. Virtually all state constitutions contain an oath clause for executive officials. ${ }^{202}$ Though the wording differs to some extent, they

\footnotetext{
the entry of an interim stay of all same-sex marriages in San Francisco); News Release, Office of the City Att'y, Herrera Sues State in Original Action, Forcing Constitutional Questions on Marriage Between Same-Sex Couples (Mar. 11, 2004), http://www.sfgov.org/site/cityattorney_page.asp?id=23406 (announcing San Francisco's compliance with the court-ordered stay).

${ }^{201}$ See, e.g., CAL. CONST. art. III, § 3.5 (barring "administrative agenc[ies]" from refusing to enforce a statute on constitutional grounds).

${ }^{202}$ Only Arizona, Idaho, North Dakota, and Washington lack a constitutionally prescribed oath for executive officers. See ARIz. CONST. art. VI, § 26 (requiring an oath only for judges); IDAHO CONST. art. III, $§ 25$ (requiring an oath only for legislators);
} 
all provide in substance that the sworn officer "support" or "support and defend" the state and federal constitutions. ${ }^{203}$ Some state courts have read this language as empowering all sworn officers to act on their own best understanding of the constitution. ${ }^{204}$ The Nebraska Supreme Court, for example, declared that "officers of this state are sworn to support the constitution" and that, therefore, "[w]here a supposed act of the legislature and the constitution conflict, the constitution must be obeyed, and the statute disregarded." 205 There is an elegant appeal to this interpretation, but ultimately it is unpersuasive.

First, the oath clauses do not require officials to "interpret" or "enforce" the constitution, only to "support" it. ${ }^{206}$ That difference in

N.D. CONST. art. XI, $\S 4$ (requiring an oath only for legislators and judges); WASH. CONST. art. IV, $\S 28$ (requiring an oath only for judges of the state supreme and superior courts). North Dakota and Washington, however, require the oath of every civil officer as a statutory matter. N.D. CENT. CODE $§ 44-01-05$ (2001); WASH. REV. CODE $§$ 43.01.020 (1998).

${ }^{203}$ ALA. CONST. art. XVI, § 279; ALASKA CONST. art. 12, § 5; ARK. CONST. art. 19, § 20; CAL. Const. art. XX, § 3; Colo. Const. art. XII, $\S 8$; CONN. Const. art. XI, $\S 1$; DEL. CONST. art. XIV, § 1; FLA. CONST. art. II, § 5(b); GA. CONST. art. V, § I, I VI; HAW. CONST. art. XVI, $\S 4$; ILl. CONST. art. XIII, $\S 3$; IND. CONST. art. 15, $\$ 4$; IOWA CONST. art. XI, § 5; KAN. CONST. art. 15, § 14; KY. CONST. § 228; LA. CONST. art. X, § 30; ME. CONST. art. IX, § 1; MD. Const. art. 1, § 9; MASs. Const. pt. 2, ch. VI, art. I; MiCH. CONST. art. XI, § 1; MinN. Const. art. V, § 6; Miss. Const. art. 14, § 268; Mo. CONST. art. VII, § 11; MONT. CONST. art. III, § 3; NEB. CONST. art. XV, § 1; NEV. CONST. art. 15, $\S 2$; N.H. Const. pt. 2, art. 84; N.J. ConST. art. VII, § I, I 1; N.M. CONST. art. XX, § 1; N.Y. CONST. art. XIII, § 1; N.C. CONST. art. III, § 4, art. VI, § 7; OHIO CONST. art. 15, § 7; OKLA. CONST. art. XV, § 1; OR. CONST. art. XV, § 3; PA. CONST. art. VI, § 3; R.I. CONST. art. III, § 3; S.C. Const. art. VI, § 5; S.D. CONST. art. XXI, § 3; TEnN. ConST. art. X, § 1; TeX. CONST. art. 16, § 1; UTAH CONST. art. IV, § 10; VT. CONST. ch. II, § 56; VA. Const. art. II, § 7; W. VA. CONST. art. IV, §§ 4-5; WIS. CONST. art. IV, § 28; WYO. CONST. art. $6, \S 20$.

${ }^{204}$ See, e.g., City of Montpelier v. Gates, 170 A. 473, 476-77 (Vt. 1934) (holding that officers may challenge the constitutionality of a statute because it is their "sworn duty to execute their respective offices 'according to law'").

${ }^{205}$ Van Horn v. State ex rel. Abbott, 64 N.W. 365, 372 (Neb. 1895). In a similar vein, Chief Justice Marshall invoked the Oath Clause from the Federal Constitution in defending the existence of judicial review in Marbury v. Madison. See 5 U.S. (1 Cranch) 137, 180 (1803) (arguing that a judge's oath to perform her duties in accordance with the Constitution has no purpose if not to guarantee judicial enforcement of the Constitution). Marshall's interpretation of the Oath Clause was rejected in the famous dissent by Justice Gibson in Eakin v. Raub, 12 Serg. \& Rawle 330, 352 (Pa. 1825) ("The oath to support the constitution is not peculiar to the judges, but is taken indiscriminately by every officer of the government, and is designed rather as a test of the political principles of the man, than to bind the officer in the discharge of his duty . . ..”). See also William W. Van Alstyne, A Critical Guide to Marbury v. Madison, 1969 DukE L.J. 1, 25-26 (discussing Gibson's critique).

${ }^{206}$ The one potentially notable exception is Vermont, which requires officials to swear that they "will not, directly or indirectly, do any act or thing injurious to the Con- 
language is crucial since one can support a constitution without enforcing it. Take, for example, a state official who swears allegiance to Iran or North Korea but who continues to perform her statutory obligations in a normal fashion. Has she violated her oath? Most of us would say, yes, she has, but that can only be true if the requirement to "support" the constitution differs from the duty to "enforce" the constitution. The oath does not address how one discharges one's public duties; rather, it signifies one's loyalty to the government created by the constitution. ${ }^{207}$

This conception of the oath clauses is bolstered by the scope of the provisions. The California oath, for example, must be taken by "all public officers and employees," which includes "every officer and employee of the State, including the University of California, every county, city, city and county, district, and authority, including any department, division, bureau, board, commission, agency, or instrumentality of any of the foregoing." ${ }^{208}$ According to the California Attorney General, even the state's elevator and boiler inspectors must swear the constitutionally prescribed oath. ${ }^{209}$ The Oregon oath, in turn, must be taken by "[e]very person elected or appointed to any office under this Constitution." ${ }^{210}$ The breadth of these provisions suggests that the re-

stitution or Government thereof.” VT. CONST. ch. II, § 56.

${ }^{207}$ See, e.g., Cohen v. Wright, 22 Cal. 293, 309 (1863) (holding that the oath required is to support the government created by the constitution); Eakin, 12 Serg. \& Rawle at 353 ("The oath to support the constitution ... is designed rather as a test of the political principles of the man, than to bind the officer in the discharge of his duty ...."); David P. Bryden, The Lost Union Card, 63 Tul. L. REv. 1305, 1311 (1989) (agreeing with Justice Gibson's dissent in Eakin that the oath "may be merely an affirmation of loyalty to the political principles of the nation, not a promise to judge in a certain way or ways"); see also Paulsen, supra note 2, at 261 (acknowledging that the oath to "support" the Constitution may only require political loyalty, unlike the President's oath to "preserve, protect and defend" the Constitution).

${ }^{208}$ CAL. CONST. art. XX, § 3; see also CAL. GOV'T CODE $\$ 18150$ (West 1995) (requiring an oath of all state employees, both within and without civil service). There is an irony in San Francisco's reliance on the oath. The clause expressly empowers the Legislature to exempt "inferior officers and employees." CAL. CONST. art. XX, § 3. Thus, if San Francisco is right about the source of its interpretive authority, its officials' authority to act as they did is subject to legislative control.

20928 Op. Cal. Att'y Gen. 46 (1956).

${ }^{210}$ OR. CONST. art. XV, § 3; see also ALA. CONST. art. XVI, § 279 (requiring oath of "all officers, executive and judicial"); ALASKA CONST. art. 12, § 5 ("public officers"); ARK. CONST. art. 19, $\$ 20$ ("all judicial and executive, State and county officers"); COLO. CONST. art. XII, $\S 8$ ("[e]very civil officer”); CONN. CONST. art. XI, $§ 1$ ("all officers, executive and judicial”); DEL. CONST. art. XIV, 11 ("all public officers executive and judicial"); FLA. CONST. art. II, $\S 5$ (b) ("[e]ach state and county officer"); HAW. CONST. art. XVI, $\$ 4$ ("[a]ll eligible public officers, [including] . . state or county employees who possess police powers”); ILL. CONST. art. XIII, $\S 3$ (all holders of state of- 
quired oath relates only to the official's or employee's loyalty, not to the manner in which the official or employee discharges her responsibilities. After all, there is no conceivable purpose in requiring every government officer or employee (say, a janitor at the State Capitol building) to oblige herself to consider constitutional claims in performing her daily job duties.

Second, even if "support" and "enforce" were synonymous, one would still need a theory regarding how the executive "enforces" the constitution. The San Francisco and Multnomah County officials assumed that all executive officials enforce the constitution by refusing to administer putatively unconstitutional statutes, but that is an assumption, not a necessary corollary of the executive power. One might take the view adopted by the California Supreme Court in Lockyer that the executive enforces the constitution by administering the statute as drafted by the legislature, leaving it to the courts to resolve the constitutional question. ${ }^{21}$ More modestly, one might take

fice); IND. CONST. art. 15, §4 ("every person elected or appointed to any office”); IOWA CONST. art. XI, $\S 5$ ("every person elected or appointed to any office"); KAN. CONST. art. 15, § 14 (“[a]ll state officers"); KY. CONST. § 228 ("all officers"); LA. CONST. art. X, $\S 30$ ("[e]very official”); ME. CONST. art. IX, § 1 ("every person elected or appointed"); MD. CONST. art. 1, §9 (all elected or appointed officers); MICH. CONST. art. XI, $\$ 1$ ("all officers"); MINN. CONST. art. V, § 6 ("[e]ach officer"); MISS. CONST. art. 14, § 268 ("all officers elected or appointed to any office"); MO. CONST. art. VII, § 11 ("all civil and military officers"); MONT. CONST. art. III, $\$ 3$ ("all executive, ministerial and judicial officers"); NEB. CONST. art. 15, § 1 ("executive and judicial officers"); NEv. CONST. art. 15, § 2 ("all officers, executive, judicial and ministerial"); N.H. CONST. pt. 2, art. 84 (all civil officers); N.J. CONST. art. VII, § I, II 1 (“[e]very State officer”); N.M. CONST. art. XX, § 1 ("every person elected or appointed to any office"); N.Y. CONST. art. XIII, $\S 1$ ("all officers, executive and judicial"); N.C. CONST. art. VI, $§ 7$ (any "person elected or appointed to [an] office"); OHIO CONST. art. 15, $\$ 7$ ("every person chosen or appointed to any office"); OKLA. CONST. art. XV, 1 ("all public officers"); PA. CONST. art. VI, § 3 ("all judicial, State and county officers"); R.I. CONST. art. III, § 3 ("all general officers"); S.C. CONST. art. VI, $§ 5$ ("all officers”); S.D. CONST. art. XXI, § 3 (all elected or appointed officers); TENN. CONST. art. X, $\$ 1$ ("every person who shall be chosen or appointed to any office"); TEX. CONST. art. 16, § 1 ("all elected and appointed officers"); UTAH CONST. art. IV, § 10 ("all officers made elective or appointive by this Constitution"); VT. CONST. ch. II, $\$ 56$ ("every officer"); VA. CONST. art. II, $\$ 7$ ("all officers elected or appointed"); W. VA. CONST. art. IV, § 5 ("every person elected or appointed to any office"); WIS. CONST. art. IV, $\$ 28$ ("all officers, executive and judicial"); WYO. CONST. art. 6, § 20 ("all judicial, state and county officers"). But see GA. CONST. art. V, § I, II VI (requiring the oath only of the governor and lieutenant governor).

${ }^{211}$ See Lockyer v. City \& County of San Francisco, 95 P.3d 459, 485 (Cal. 2004) ("[A] public official 'faithfully upholds the Constitution by complying with the mandates of the Legislature, leaving to courts the decision whether those mandates are invalid." (quoting S. Pac. Transp. Co. v. Pub. Utils. Comm'n, 556 P.2d 289, 319 (Cal. 1976) (Mosk, J., concurring and dissenting))). That also appears to be Justice Story's 
the position that the executive enforces the constitution by bringing suit to challenge the constitutionality of a statute that it thinks dubious. ${ }^{212}$ And, finally, one might take the position that only the governor or other constitutional officers may refuse to administer a statute according to its terms. ${ }^{213}$

This is not the place to identify which of the foregoing conceptions of executive enforcement is the right one, but the version defended by San Francisco and Multnomah County is not it, at least as a constitutional matter. ${ }^{214}$ Their conception is too demanding. To see why, recall that their argument is that the oath to support and defend the constitution obligates all sworn officers to administer their duties according to their best understanding of what the constitution requires. This obligation is not particular to any specific duty or statute; it is global. Sworn executive officials do not get to pick and choose the instances in which they will act on their constitutional scruples; rather, all sworn executive officials must ensure that every action they undertake comports with the constitution. ${ }^{215}$

But there's the problem: no one can reasonably expect executive officials to be that fastidious about the constitution. Most officials do not have the knowledge or predisposition to undertake such an examination every day with regard to every task. The clerk at the department of social services, for example, is in no position to determine, when presented with a claim for welfare benefits, whether the bill requiring her to pay the welfare benefits was enacted by the legis-

view of the Federal Oath Clause. See Joseph Story, Commentaries On the ConstiTUTION OF THE UNITED STATES 702-05 (Boston, Hilliard, Gray, \& Co. 1833) (arguing that the Oath Clause requires state officials to discharge federal constitutional duties but never suggesting that this includes refusing to enforce a state statute that an official thought violated the Federal Constitution).

${ }^{212}$ See Bd. of Educ. v. Allen, 392 U.S. 236, 241 n.5 (1968) (holding that state officials had standing to challenge the constitutionality of a state statute that they enforced). But see supra notes 179-83 and accompanying text (discussing officials' lack of standing to sue to enjoin statutes they are charged to enforce).

${ }^{213}$ This appears to have been the position of the Oregon Supreme Court in CooperEugene. See Cooper v. Eugene Sch. Dist. No. 4J, 723 P.2d 298, 303 n.7 (Or. 1986) (observing, after noting the oath clause, that the superintendent of public instruction is a constitutional officer of the state); see also infra Part IV.C (discussing the role of the governor in enforcing the constitution).

${ }^{214}$ Of course, the legislature could adopt San Francisco's and Multnomah County's model as a statutory matter, thereby authorizing all executive officials to disregard statutory duties when they believe the constitution requires it.

${ }^{215}$ Cf. Johnsen, supra note 3, at 19 (arguing that the President may not "pick and choose" which unconstitutional duties she may refuse to perform if the oath obligates her to enforce the Constitution). 
lature via the constitutionally prescribed procedure, or whether the governor's line item veto of the welfare-benefit provision in the bill was constitutionally valid. ${ }^{216}$ And, even officials who are knowledgeable about certain constitutional provisions, such as police officers with respect to the Fourth Amendment's prohibition on unreasonable searches and seizures, may properly choose to act in a constitutionally questionable way in the belief that it is for the courts to determine ultimately whether the officer's conduct was lawful. ${ }^{217}$ Indeed, both federal and state law encourages such envelope-pushing conduct so as to ensure the effective discharge of statutorily assigned duties. ${ }^{218}$ In these circumstances, it cannot be that these officials have violated their oath when courts subsequently decide that their action was unconstitutional.

The same problem can be seen in another way. Did the County Clerks in San Francisco and Multnomah County violate their oath earlier in 2004 when they turned away same-sex couples? ${ }^{219}$ Neither the California nor the Oregon Constitution changed between January 2004 and March 2004, so the Clerks cannot insist that, in fact, they were enforcing the constitution at all times. Perhaps they could respond that they did not know what the constitution required until February 2004, but the oath clauses conspicuously lack a scienter requirement (e.g., "to knowingly support and defend this constitution"). Alternatively, they could argue that they were not prepared to act on

${ }^{216}$ Cf. Harbor v. Deukmejian, 742 P.2d 1290, 1292, 1303 (Cal. 1987) (invalidating a legislative bill requiring additional welfare benefits for violating the single-subject requirement of California's Constitution, and also invalidating the Governor's line item veto of same because the bill was not an appropriations measure).

${ }^{217}$ Cf. Welsh v. Wisconsin, 466 U.S. 740, 753 (1984) (holding that a warrantless entry into a home to arrest an individual for a minor traffic violation violated the Fourth Amendment). During the same-sex marriage controversy in California, Governor Schwarzenegger adopted this position. See Press Release, Arnold Schwarzenegger, Governor of California, Statement by Governor Schwarzenegger on California Supreme Court Action Regarding Same-Sex Marriage (Mar. 11, 2004), available at http://www.governor.ca.gov/govsite/press_release/2004_03/20040311_GAAS9304_

Same_Sex_Supreme_Court_Statement.html ("The judicial system is the appropriate venue for resolving questions pertaining to the constitutionality of our state laws.").

${ }^{218}$ See, e.g., Harlow v. Fitzgerald, 457 U.S. 800, 818 (1982) (holding that government officials are "shielded from liability ... insofar as their conduct does not violate clearly established statutory or constitutional rights of which a reasonable person would have known" (emphasis added)); CAL. GOV’T CODE $\$ 820.6$ (West 1995) (granting immunity to public employees who act "in good faith" under the "apparent authority of an enactment that is unconstitutional, invalid or inapplicable").

${ }^{219}$ See Austin, supra note 87, at A1 (reporting how Multnomah County officials turned away same-sex couples in late February 2004, just days before changing their policy). 
their constitutional views until February 2004, but the oath clauses do not make the support of the constitution discretionary (e.g., "to support this constitution to the best of your abilities" or "to support this constitution when you feel like it").

The Nebraska Supreme Court attempted to address this problem by superimposing a "clear error" requirement to excuse executive enforcement of constitutionally suspicious statutory duties. After justifying executive review by reference to the constitutionally required oath, the court advised executive officials to "exercise the greatest caution" and to disregard statutory duties "only in clear cases of unconstitutionality." 220 This limitation on executive review solves the overdemandingness problem, but there is absolutely no textual warrant for the court to engraft such a limitation on the supposed duty. The oath clauses do not contain any such constraint-i.e., "support and defend this constitution against clear violations"-and it is indefensible for a court to impose one by implication. After all, if the oath obligates all executive officials to enforce the constitution, the court has no business excusing executive noncompliance with that constitutional duty.

Third, even if an official were able to surmount the foregoing analytical problems and demonstrate that the oath obligates her to perform her statutory duties in accordance with the constitution, she would still need to prove that it is her understanding of the constitution, not some other body's (such as the supreme court's or governor's), that matters. The oath clauses are silent regarding whose interpretation of the constitution the officials are swearing to uphold. Given that silence, it is possible that the oath allows each sworn official to draw her own understanding of the constitution, but that is certainly not the only plausible reading. Most courts that have addressed the oath clauses have read them to require obeisance to the judiciary's interpretation of the constitution. ${ }^{221}$ And, for those opposed to the system of judicial supremacy implicit in those decisions, it is surely more defensible to believe that executive officials are bound by the governor's or attorney general's interpretation of the constitution

${ }^{220}$ Van Horn v. State ex rel. Abbott, 64 N.W. 365, 372 (Neb. 1895).

${ }^{221}$ See, e.g., State ex rel. Atl. Coast Line R.R. Co. v. State Bd. of Equalizers, 94 So. 681, 683 (Fla. 1922) (““[T] o obey the Constitution’ means to obey the Constitution, not as the officer decides, but as judicially determined.”); State ex rel. Clinton Falls Nursery Co. v. Steele County Bd. of Comm'rs, 232 N.W. 737, 738 (Minn. 1930) (“[An official's] oath does not require him to obey the Constitution as he decides, but as judicially determined."). 
than that they are allowed to act on their own subjective views.

What the foregoing discussion makes clear is that the obligation to "support and defend" the constitution does not carry with it the duty for all sworn executive officials to perform their statutory tasks in accordance with the constitution as they understand it. The San Francisco and Multnomah County officials did not violate their oaths in refusing marriage licenses to same-sex couples in January 2004, but, by the same token, those oaths did not obligate or authorize them to issue those licenses in March 2004.

\section{B. An Unconstitutional Law Is "No Law at All"}

A slightly different argument in favor of a constitutional right to engage in executive review focuses on the juridical status of unconstitutional statutes. According to this argument, there is no duty to enforce an unconstitutional statute because such a statute "is no law at all."222 Drawing from Marbury, the Nebraska Supreme Court, for instance, declared that "the constitution is the fundamental law; that an act of the legislature repugnant thereto is not merely voidable by the courts, but is absolutely void, and of no effect whatever. It is no law, and binds no one to observe it." ${ }^{223}$ Hence, while not expressly conferred by the constitution as a right, the authority to refuse to enforce a statute flows from the status of the statute as nonlaw.

There is obviously a great deal of appeal to this argument, but its appeal is more rhetorical than real. The problem is that this argument does not accurately capture how we treat statutes, even unconstitutional ones. It might be nice to say that unconstitutional statutes are void ab initio, but the reality is that such statutes do confer rights, duties, and obligations until some authoritative agent pronounces them void. Indeed, numerous doctrines, such as statutes of limitations and

${ }^{222}$ Holman v. Pabst, 27 S.W.2d 340, 342 (Tex. Civ. App. 1930); see also State ex rel. Test v. Steinwedel, 180 N.E. 865, 867 (Ind. 1932) (approving the Utah Supreme Court's view that "[i]f the legislative enactment under which [an officer] is required to act is in conflict with the Constitution, the Constitution and not the enactment prevails, and the officer must obey the Constitution or violate his oath of office"); State ex rel. Pierce v. Slusher, 248 P. 358, 360 (Or. 1926) ("Our [nation's] highest court has declared that an unconstitutional law is no law ...." (citing Poindexter v. Greenhow, 114 U.S. 270 (1885))); City of Montpelier v. Gates, 170 A. 473, 476 (Vt. 1934) ("[A]n unconstitutional statute is a mere nullity that confers no rights, imposes no duties, and affords no protection.”); State ex rel. McCurdy v. Tappan, 29 Wis. 664, 686 (1872) ("The act being void, it binds no one, and any person may assert its true character and refuse to obey it.").

${ }^{223}$ Van Horn, 64 N.W. at 372. 
constraints on habeas corpus relief, operate to give legal effect to otherwise unconstitutional conduct. For example, a particular tax may be unconstitutional, but no taxpayer will get a refund of any taxes paid more than three years earlier. ${ }^{224}$ For this reason, it is better to speak of allegedly unconstitutional statutes as voidable rather than void.

Moreover, it would be far too disruptive to treat unconstitutional statutes as void ab initio. Consider a (not too) hypothetical statute that requires property owners to provide an easement for the public to cross their land in order to get access to a beach. Pursuant to the statute, a landowner opens the statutorily required easement, and numerous individuals take advantage of the easement, regularly crossing the land. Now suppose that a court subsequently invalidates the statute as unconstitutional under the Takings Clause. ${ }^{225}$ May the property owner sue all of the individuals who used the easement for trespass and recover damages from them? Surely not; the individuals would quite properly respond that they were entitled to rely on the now-unconstitutional statute, which privileged their conduct. ${ }^{226}$ Indeed, were that not the case, compliance with statutory provisions, both constitutional and unconstitutional, would be handicapped. Individuals would refuse to comply with questionable statutory directives for fear of incurring liability in the future if the statute turned out to be unconstitutional.

Proponents of universal executive review may respond that, fair enough, unconstitutional laws are merely voidable and therefore valid until declared otherwise by an authoritative agent, but argue that each executive official is an authoritative agent for deciding such unconstitutionality. That does not follow, however, from the jurisprudential status of unconstitutional statutes as voidable; rather, that proposition must be defended on other grounds, such as that the executive power necessarily includes the power to decide the constitutionality of statutes. There may be some high-ranking executive officials for whom that is true-I address that more circumscribed claim for a constitutional right to engage in executive review below-but that is because of features unique to those officers, not because such interpretive au-

${ }^{224}$ See, e.g., 26 U.S.C. $\$ 6511$ (a) (2000) (stating that a claim for refund of tax paid must be brought within three years of filing a return).

${ }^{225}$ Cf. Nollan v. Cal. Coastal Comm'n, 483 U.S. 825, 839 (1987) (holding that the commission's imposition of a beach-access easement as a condition to granting a development permit was an unconstitutional taking).

${ }^{226}$ See RESTATEMENT (SECOND) OF TORTS $\$ 211$ (1965) (acknowledging a privilege to enter land pursuant to legislatively granted authority). 
thority is inherent in the executive function. For "ordinary" executive officials, such as clerks at the local welfare office, there can be no reasonable claim that the power to interpret and enforce the constitution is, as a constitutional matter, included in their job description. If such officials have such interpretive power, it is because something other than the constitution entrusts it to them.

\section{Statutory Regulation of Executive Review}

State constitutions, properly read, neither forbid nor compel executive review. So, where does that leave executive review? Where it belongs: in the legislature. As this Part illuminates, the authority of a nonconstitutional officer to engage in executive review is subject to legislative control. In contrast, constitutional officers, such as the governor, are free to engage in executive review but only in the performance of their constitutionally assigned powers and duties.

\section{A. The Legislative Model}

Like the California Supreme Court, the Oregon Supreme Court also held that the county officials in Multnomah County had acted illegally in issuing marriage licenses to same-sex couples. The Oregon Supreme Court, however, did not follow Lockyer, which it did not mention. Rather, the court held that the County Clerks had acted illegally because the marriage statute imposed only ministerial duties upon them and, in so doing, precluded them from considering constitutional objections to the statute. ${ }^{227}$

The groundwork for the Oregon Supreme Court's approach had been laid twenty years earlier in Cooper v. Eugene School District No. 4J. ${ }^{228}$

${ }^{227}$ The court held:

$[\mathrm{T}]$ he county erroneously transmogrified a governmental official's ongoing obligation to support the constitution into an implied grant of authority, respecting any laws that the official must administer, to prescribe remedies for any perceived constitutional shortcomings in such laws without regard to the scope of the official's statutory authority to act. Li v. State, 110 P.3d 91, 101 (Or. 2005).

${ }^{228} 723$ P.2d 298 (Or. 1986). To avoid confusion with the U.S. Supreme Court's decision in Cooper v. Aaron, see supra notes 194-200 and accompanying text, I refer to the Oregon Supreme Court's decision as Cooper-Eugene. Cooper-Eugene involved the authority of the state superintendent of public instruction to consider constitutional objections during a formal hearing regarding the revocation of a public school teacher's instructional license. Ironically, the Superintendent had refused to consider the constitutional claim because, despite a contrary opinion from the then-Attorney General, the Superintendent believed that he was without authority to address constitutional 
In that case, the court had expressly declared that executive review was compatible with judicial review:

Long familiarity with the institution of judicial review sometimes leads to the misconception that constitutional law is exclusively a matter for the courts. To the contrary, when a court sets aside government action on constitutional grounds, it necessarily holds that legislators or officials attentive to a proper understanding of the constitution would or should have acted differently. ${ }^{229}$

At the same time, though, the court rejected the other extreme that every official, no matter how minor, was entitled to interpret and enforce the constitution. Rather, as the court saw it, it was "a question of interpreting the agency's statutory duties." ${ }^{230}$ Some public officials were statutorily authorized to consider constitutional claims; some were not.

Although most courts embrace one of the foregoing constitutional models, Oregon is not alone in treating the issue of executive review as one for the legislature to address in the first instance. The United States Court of Appeals for the District of Columbia, applying the domestic law of the District, also viewed the right of an executive official to refuse to enforce a statute on constitutional grounds as turning upon the statutory authority of the official. ${ }^{231}$ The panel opinion in that case was authored by no less than future Supreme Court Chief Justice Fred Vinson and was joined by future Supreme Court Associate Justice Wiley Rutledge.

More to the point, this approach is the right one on the merits. First, as a structural matter, the legislature's power to control which officials may engage in executive review flows from its greater power regarding the establishment of executive offices. The legislature may create administrative offices and delegate certain powers and responsibilities to the officials who staff the various offices. In so doing, the legislature is free to shape or limit the recipient officials' authority as it sees fit. ${ }^{232}$ Thus, for example, the legislature has the power to create

\footnotetext{
objections to the statute he administered. $I d$. at 302 .

${ }^{229}$ Id. at 303 .

${ }^{230} I d$.

${ }^{231}$ Panitz v. District of Columbia, 112 F.2d 39, 41-42 (D.C. Cir. 1940); see also Att'y Gen. v. Taubenheimer, 164 N.Y.S. 904, 905 (App. Div. 1917) (refusing to allow a town supervisor to raise a constitutional defense to nonenforcement of a tax statute "until the law makes some provision for a supervisor to become the general guardian of the taxpayers of his township").

${ }^{232}$ Cf. Calabresi \& Prakash, supra note 4, at 592-93 (noting that Congress may shape the power of administrative officials of its creation).
} 
an administrative board to review local land use decisions, and that power includes the authority to determine what factors the board shall consider in performing that review. It may empower the board to overturn local decisions only for violating state statutory land use guidelines, for violating the takings clauses, or for imposing a regulatory burden that decreases the value of affected properties by more than a given percentage. The selection is for the legislature to make. ${ }^{233}$ The legislature's power, of course, is subject to applicable constitutional limitations, but, as argued above, there is no constitutional prohibition on executive review nor any constitutional right to such action.

Second, entrusting this decision to the legislature also makes sense as a policy matter. In a regime without executive review, individuals would have to seek out and secure a judgment by a court of competent jurisdiction to vindicate their constitutional rights. In a regime with unfettered executive review, officials might refuse to take statutorily mandated action on grounds that subsequently turn out to be erroneous. In short, there is a tension between the orderly administration of the laws and the full enforcement of constitutional rights and norms.

The protagonists in this debate often simply take one side, trumpeting one of the values and disparaging the other. Thus, opponents of executive review typically emphasize the disorder and chaos that executive review would allegedly produce, ${ }^{234}$ while proponents of executive review argue that the absence of such power would leave constitutional rights underprotected. ${ }^{235}$ Yet, the competing values in this debate cannot be ordered a priori; they are both necessary ingredients in a well-functioning constitutional democracy. Absolute order in the administration of the laws would hardly be desirable if the price were routine violations of constitutional norms; likewise, striving for constitutional perfectionism would surely be undesirable if the cost were bureaucrats routinely undertaking action at odds with their statutory duties because, in their erroneous view, the constitution licenses such action.

${ }^{233}$ See, e.g., State v. Sproles, 672 N.E.2d 1353, 1360-61 (Ind. 1996) (holding that it is for the legislature to decide whether the department of state revenue can consider a constitutional challenge to a tax and, if so, whether the exhaustion doctrine applies).

${ }^{234}$ See supra note 184 and accompanying text.

235 See, e.g., Van Horn v. State ex rel. Abbott, 64 N.W. 365, 372 (Neb. 1895) ("If an act must be respected until its validity is declared by the judiciary in a proper proceeding, then the constitution is utterly ineffectual."). 
Obviously, balancing the twin needs of orderly administration and constitutional enforcement entails making difficult empirical judgments about the costs and benefits of executive review in particular statutory contexts. And, equally obviously, courts are ill-equipped to make these judgments. Indeed, the Indiana Supreme Court expressly noted the fact that it lacked a "reliable source of information from which to accurately evaluate the relative advantages or disadvantages" of executive review. ${ }^{236}$ Legislatures, in contrast, do have the resources to make these types of judgments, and, if they err, their decisions regarding which officials to allow to engage in executive review can be undone.

No doubt there will be many individuals who will object to the notion of entrusting the legislature with this authority. Surely, they will argue, this is too important a decision to leave to the mundane political world of state legislatures. Echoing James Madison and modern public choice theorists, ${ }^{237}$ they will contend that the state legislative process is ripe for abuse or capture by special interest groups and that these groups will manipulate the process to ensure that the legislature authorizes executive review only by officials sympathetic or beholden to those groups. Moreover, those familiar with the public choice literature may argue that groups are more likely to focus their energy on securing the power of executive review for officials sympathetic to the groups than to lobby for substantive policy outcomes because the latter generate greater public scrutiny and potential political opposition. The administrative law literature is rife with claims that special interest groups lobby Congress to delegate important policy decisions to administrative agencies precisely because it is easier for the groups to prevail substantively in administrative agencies than in Congress. ${ }^{238}$ In

${ }^{236}$ State ex rel. Test v. Steinwedel, 180 N.E. 865, 867 (Ind. 1932). In contrast, the Maryland Court of Appeals views it as within its discretion to determine when to consider a constitutional defense proffered by an official. See Md. Classified Employees Ass'n v. Anderson, 380 A.2d 1032, 1037 (Md. 1977) (exercising discretion to allow a county to challenge the constitutionality of an ordinance).

${ }^{237}$ See The FEDERALIST No. 10, at 77 (James Madison) (Clinton Rossiter ed., 1961) (discussing the susceptibility of state and local governments to factionalism); Einer R. Elhauge, Does Interest Group Theory Justify More Intrusive Judicial Review?, 101 YALE L.J. 31, 35-43 (1991) (describing special interest group influence on legislation); Daniel A. Farber \& Philip P. Frickey, The Jurisprudence of Public Choice, 65 TEX. L. REV. 873, 875-83 (1987) (surveying scholarship on the influence of special interest groups on legislation).

${ }^{238}$ See, e.g., Peter H. Aronson et al., A Theory of Legislative Delegation, 68 CORNELL L. REv. 1, 57 (1982) (noting that special interest groups may seek to lobby for delegation of regulatory powers to administrative agencies). 
a similar vein, it might be easier for special interest groups to obtain legislation authorizing executive review by a particular official, who the groups would hope would use the power in a favorable way, than to achieve directly their policy aims. According to this view, the gayrights community, for example, is more likely to be successful in persuading the legislature to authorize executive review by county clerks (because that is not likely to generate the same counterreaction by groups opposed to same-sex marriage) than in getting the legislature to license same-sex marriage.

One should not be too glib in dismissing this concern. State legislatures are not utopian deliberative institutions immune from factional politics, ${ }^{239}$ and, therefore, one has to credit the possibility that legislative decisions regarding executive review will become the fodder of special interest group pressure. Nevertheless, in my view, this concern about the state legislative process is not fatal. Jerry Mashaw has convincingly demonstrated that, because of its very universality, special interest group pressure does not distort the legislative process in the systemic, pro-delegation way that public choice theorists presume. $^{240}$ The same political alignments that operate with regard to any given substantive policy choice (e.g., same-sex marriage) will operate with regard to the secondary, executive review decision relevant to that choice (e.g., whether county clerks can consider constitutional claims in issuing marriage licenses). Thus, for example, while the gayrights community may seek executive review by county clerks, groups opposed to same-sex marriage will likewise understand what is going on and will oppose such authority.

More importantly, though, this concern is not unique to executive review but applies to all questions of legislative delegations of authority to administrative or executive officials. Special interest groups may seek to delegate policy questions to favored agencies or officials, but there is no reason a priori to believe that the decision whether to delegate executive review authority is subject to any greater or different special interest group pressure than the question whether to delegate legislative authority generally. To the extent that one is worried that certain special interest groups may have unfair or disproportionate influence in the legislative or administrative processes, executive review should be the least of one's worries.

239 See Norman R. Williams, Why Congress May Not "Overrule" the Dormant Commerce Clause, 53 UCLA L. REV. 153, 224 (2005) ("[S] tate political processes are particularly susceptible to the ravages of rent-seeking behavior by special interest groups.”).

${ }^{240}$ JERRY L. MASHAW, GREED, CHAOS, AND GOVERNANCE 146-47 (1997). 
In short, the legislative model eschews the opposite extremes in the debate over executive review, both of which seek a constitutionally grounded categorical rule. Rather, it acknowledges the need for both order and constitutional compliance and accepts that balancing the two values entails difficult judgments of the sort best left to the legislature.

\section{B. Statutory Indicia of the Delegation of Interpretive Authority}

Embracing the legislative model presents the ticklish problem of identifying what qualifies as a delegation of constitutional interpretive authority. Specifically, what type of statutory authorization is necessary for an executive official to be able to consider constitutional claims in performing her statutory duties? Obviously, an express delegation of such interpretive authority is sufficient, ${ }^{241}$ but such explicit delegations are rare. ${ }^{242}$ Rather, the existence of such authority will often have to be inferred from other indicia.

One salient factor to consider is whether the official must use some formal process for discharging her statutory duties. The Oregon Supreme Court has suggested that the legislative requirement that certain officials conduct formal adjudicatory hearings under the state Administrative Procedures Act indicates a legislative delegation of interpretive authority. ${ }^{243}$ By negative implication, this view suggests that executive officials empowered to issue orders only through informal adjudicatory processes do not possess such interpretive authority. ${ }^{244}$

${ }^{241}$ See Cooper v. Eugene Sch. Dist. No. 4J, 723 P.2d 298, 303 (Or. 1986) ("The agency's duty to decide such challenges would not be doubted if the legislature provided for it expressly ....").

${ }^{242}$ See, e.g., OR. REV. STAT. $\$ 197.835$ (b) (2003) (empowering the Oregon Land Use Board of Appeals to consider constitutional objections to land use regulations).

${ }^{243}$ See, e.g., Li v. State, 110 P.3d 91, 101-02 (Or. 2005) (noting that a state official vested with "quasi-judicial authority"-referring to the authority to issue orders in contested cases under Oregon's Administrative Procedures Act-could consider constitutional claims). The Cooper-Eugene court remarked:

The agency's duty to decide [constitutional] challenges would not be doubted if the legislature provided for it expressly rather than doing so implicitly under the general term "law" in the Administrative Procedure[s] Act provisions that require a final order in a contested case to include the agency's conclusions of law ... and subject the order to reversal if it violates a constitutional provision. 723 P.2d at 303 (citations omitted).

${ }^{244}$ The court in Cooper-Eugene had obliquely suggested that officials in noncontested cases possessed interpretive authority. See 723 P.2d at 303 (citing both OR. REv. STAT. $\$ 183.482$ (2003) (judicial review of contested agency orders) and $\S 183.484(3)$ 
One might doubt whether the degree of procedural formality required by the legislature perfectly correlates with its intent to imbue a given official with the authority to consider constitutional claims in performing her statutory duties, but it is at least reasonable to assume that such formality is a good proxy for such legislative intent. ${ }^{245}$ After all, if the legislature intended for a given official to consider constitutional claims, one would ordinarily expect the legislature to require the type of process in which the official could amass the necessary information and arguments to perform that task in a thorough fashion.

Another factor to consider is the nature and scope of discretion entrusted to the executive official. The Oregon Supreme Court seemed to consider the existence of any discretion as indicative of the possession of interpretive authority. ${ }^{246}$ As an example, the court suggested that prosecutors may refuse to indict an individual "under a statute of questionable constitutional validity." ${ }^{247}$ A prosecutor has virtually unfettered discretion regarding who to indict and prosecute, ${ }^{248}$ and, for that reason, the court was right that a prosecutor does not act in an ultra vires fashion by refusing to indict an individual because of concerns about the constitutionality of the prosecution.

Nevertheless, one should be careful in linking the existence of discretion vel non with constitutional interpretive authority. Obviously, each official's discretion varies in scope. Some officials have a large amount of discretion (like prosecutors); others do not (like county clerks). ${ }^{249}$ The mere fact that the legislature has given some degree of choice in whether or how a given duty is performed does not mean that the legislature intended for the official to exercise her discretion on any ground whatsoever. One might be safe in concluding that the greater the discretion, the greater the likelihood that the official can consider constitutional concerns in exercising the discre-

(judicial review of orders in noncontested cases) as impliedly delegating interpretive authority to state officials).

${ }^{245}$ Cf. United States v. Mead Corp., 533 U.S. 218, 230 (2001) ("It is fair to assume generally that Congress contemplates administrative action with the effect of law when it provides for a relatively formal administrative procedure ....").

${ }^{246}$ See $\mathrm{Li}, 110$ P.3d at 102 (implying that a governmental official with discretion has multiple choices in "vindicating that official's personal constitutional vision").

${ }^{247}$ Id.

${ }^{248}$ Of course, even the prosecutor's discretion could be limited by the legislature. Cf. Heckler v. Chaney, 470 U.S. 821, 832-33 (1985) (noting that Congress may provide guidelines for an agency to use in exercising enforcement authority).

249 See OR. REV. STAT. $\$ 106.077$ (2) (2003) (authorizing a clerk to waive the threeday marriage license waiting period only when there is "good and sufficient cause shown"). 
tion, but, here, there is no substitute for a probing examination of the nature of the statutory duty (e.g., whether it ordinarily implicates constitutional issues) and the statutory constraints on the official's decision-making process (e.g., whether the official may exercise her discretion only on enumerated grounds, for "good cause," or for any reason whatsoever).

Closely related to the issue of discretion is the matter of statutory ambiguity. Even an official charged with a purely ministerial function may nevertheless have authority to consider constitutional concerns in resolving statutory ambiguities. In these instances, the presence of a statutory ambiguity carries with it a limited form of constitutional interpretive authority; the ambiguity can be said to serve as an implied delegation of interpretive authority, though only to the extent necessary to resolve the ambiguity. ${ }^{250}$ Thus, for example, were the legislature to require county clerks to issue marriage licenses to "qualified couples" without further defining that term, there would surely be no outcry regarding the legitimacy of the clerks' consultation of the constitution in deciding whether same-sex couples fit within the statutory term (though there may be outcry over the merits of the clerks' interpretation of the constitution).

Lastly and most problematically, the Oregon Supreme Court stated that a ministerial official could refuse to perform some statutorily mandated duty on constitutional grounds. ${ }^{251}$ Whatever the source of this statement-and the court gave none-it is theoretically indefensible to distinguish between acts of commission and acts of omission as the court attempted to do. Whether an official is performing some act beyond her statutory authority versus refusing to perform some act otherwise within her authority is irrelevant to the determination of whether the legislature has delegated interpretive authority to the official. If the county clerk cannot issue marriage licenses to samesex couples on constitutional grounds because the legislature has not delegated interpretive authority to the clerk with regard to who is entitled to marriage licenses, it is equally illegal for the county clerk to refuse to issue marriage licenses to interracial couples as required by statute on the ground that she believes the constitution forbids such marriages. In both instances, the critical question is whether the legis-

${ }^{250}$ See Mead, 533 U.S. at 229 (noting that ambiguity can be an implied delegation of law-making power).

${ }^{251}$ See Li, 110 P.3d at 102 (stating that an official with no discretion may "decline to perform a statutory duty" when the constitutional validity of the statute is in question). 
lature intended for the clerk to consider constitutional claims in issuing marriage licenses, and there is no reason to think that the legislature delegated interpretive authority in the latter instance but not in the former.

This discussion is not intended to be exhaustive; there may be other indicia of a legislative intent to delegate interpretive authority to an executive official. Of course, divining such intent may often be challenging for both officials and courts alike. To do so necessarily requires a close examination of the nature and scope of the official's power. In order to demonstrate in more detail what that examination entails, let's return to the same-sex marriage controversy and assess whether the County Clerks in Oregon and California had been delegated interpretive authority by their respective legislatures.

\section{Oregon}

In $L i$, the Oregon Supreme Court declared in a conclusory fashion that "the county's involvement in the license-issuing process is ministerial only." 252 That is true, but the court omitted the type of detailed statutory investigation required to defend such an important conclusion.

Under Oregon law, all persons wishing to marry must first obtain a marriage license from the county clerk by applying in writing on a form provided by the State Department of Human Services. ${ }^{253}$ After the county clerk "has received the written application for the marriage license from both applicants, and all other legal requirements for issuance of the marriage license have been met," the clerk "shall" issue the marriage license. ${ }^{254}$ At the same time, the clerk "shall" record in the "marriage book" the names of the applicants and other statutorily mandated information about the license. ${ }^{255}$ The clerk has no discretion to waive the foregoing requirements in issuing a marriage license and is subject to imprisonment for up to one year for violating the requirements. ${ }^{256}$

252 Id

253 OR. REV. STAT. § 106.041 (1), (3) (2003).

${ }^{254}$ Id. $\S 106.077(1)$.

255 Id. $\$ 106.100$. The clerk "shall prepare the record in the form prescribed or furnished by the state registrar upon the basis of information obtained from the parties to be married." Id. $\$ 432.405(2)$.

${ }^{256} I d$. $\$ 106.110$ ("No county clerk shall issue a license contrary to the provisions of ORS 106.041 to 106.077 or 106.100."); id. § $106.990(2)$ ("Violation of ORS $106.110 \ldots$ is punishable upon conviction by imprisonment in the custody of the De- 
Once the license is issued, the marriage must be solemnized by an authorized official. A county clerk "may" solemnize the marriage. ${ }^{257}$ After solemnizing the marriage, the celebrant must give the couple a marriage certificate, ${ }^{258}$ the form of which is prescribed by rule by the state director of human services. ${ }^{259}$ In addition, within one month of the ceremony, the celebrant "shall" deliver a marriage certificate to the county clerk that issued the marriage license. ${ }^{260}$ The county clerk "shall" file this certificate and record it in the "record of marriages." 261 In addition, the clerk "shall" transmit to the state registrar the records of all marriages returned to the clerk in the preceding month. ${ }^{262}$

As the foregoing indicates, the Oregon legislature has not expressly delegated authority to the county clerk to consider constitutional claims in the issuance of marriage licenses or recording of marriage certificates. Moreover, except with regard to solemnizing a marriage, the clerk has no choice or discretion regarding the performance of her statutory duties; the legislature repeatedly used the mandatory "shall" with regard to the issuance of the marriage license and recording of the marriage certificate. Certainly, the clerk is given no discretion regarding who is entitled to a marriage license.

True, section 106.077(1) of the Oregon Revised Statutes requires the clerk to issue a marriage license once the applications have been filed and "all other legal requirements for issuance of the marriage license have been met." ${ }^{263}$ This provision might be read to empower

partment of Corrections or county jail for not more than one year, or by a fine of not more than $\$ 500$ nor less than $\$ 100 . ”)$.

${ }^{257} I d . \$ 106.120(2)$. The clerk may adopt written procedures for waiving the fee in "exigent circumstances," and the clerk may charge up to $\$ 100$, plus actual costs, when solemnizing marriages outside of normal business hours. Id. $\S 106.120(4)$ (d) ("[T] he county clerk may establish a written procedure for waiver of the fee . . . in exigent circumstances."); id. § $106.120(5)$ (b) (authorizing a county clerk to charge up to $\$ 100$, plus costs, for the solemnization of marriage under certain circumstances).

${ }^{258}$ Id. $\$ 106.160$.

${ }^{259} I d . \$ 106.165$.

${ }^{260} I d . \S 106.170$. The two marriage certificates evidently need not be identical in form. Compare id. $\S 106.165$ (mandating "a standard form of the marriage certificate" provided to the couple), with id. $\$ 106.170$ (giving discretion regarding the form of the marriage certificate provided to the county clerk). Moreover, there is an apparent inconsistency in the Oregon statutes. Section 432.405(3) of the Oregon Revised Statutes requires the official who solemnizes the marriage to transmit a record of the marriage to the county clerk within ten days of the ceremony.

${ }^{261} I d . \$ 106.180(1)$.

${ }^{262} I d . \S 432.405(4)$. The clerk's failure to do so is a Class A misdemeanor. Id. $\S$ 432.995

${ }^{263} I d . \S 106.077(1)$. 
the clerk to decide what "other legal requirements" exist, which (so the argument would go) includes claims by individuals that the constitution obligates the state to issue a license to them. That, however, is not the most natural reading of the provision. If that were the case, one would have expected the legislature to provide for the clerk to conduct a hearing to decide the matter-after all, such constitutional claims could not be decided merely on the basis of the written application whose form is prescribed by the state director of human services and which contains minimal information. Yet, the legislature conspicuously did not empower, much less require, the clerk to conduct a hearing upon an application for a marriage license. Nor does the Oregon Administrative Procedures Act or its provision for hearings apply to county clerks. ${ }^{264}$ In light of these facts, the phrase "all other legal requirements" must refer only to those statutorily mandated concerns that the clerk can determine based solely upon the written application before her.

\section{California}

California presents a closer case than does Oregon. The California marriage process differs from the Oregon process in several, potentially significant respects. Under California law, the couple must first obtain a marriage license and certificate of registry from the county clerk. ${ }^{265}$ The form of the written application for the marriage license, the marriage license itself, and the certificate of registry is prescribed by the state registrar. ${ }^{266}$ Unlike in Oregon, however, the legislature has expressly authorized the county clerk to conduct an "examination" as part of the issuance of the marriage license. Section 354 of the Family Code provides that "if the clerk deems it necessary, the clerk may examine the applicants for a marriage license on oath at the time of the application" and "may request additional documentary proof as to the accuracy of the facts stated [in the marriage license

264 See id. § 183.310(1) (““Agency’ means any state board, commission, department, or division thereof, or officer authorized by law to make rules or to issue orders, except those in the legislative and judicial branches." (emphasis added)).

${ }^{265}$ CAL. FAM. CODE $\$ \S 350$ (a), 359 (a) (West 2004 \& Supp. 2005).

${ }^{266} I d . \S 355$ ("The forms for the application for a marriage license and the marriage license shall be prescribed by the State Department of Health Services."); CAL. HEALTH \& SAFETY CODE $§ 103125$ (West 2004 \& Supp. 2005) ("The forms for the application for license to marry, the certificate of registry of marriage including the license to marry, and the marriage certificate shall be prescribed by the State Registrar."); id. $\S 103175$ (authorizing the state registrar to designate items that must be contained in a certificate of registry of marriage). 
application]." ${ }^{267}$ Moreover, even apart from validating the information contained in the application for a marriage license, the clerk is given authority to deny a marriage license on specified grounds. ${ }^{268}$

As in Oregon, the county clerk may solemnize marriages. ${ }^{269}$ Prior to the ceremony, the celebrant may also conduct an "examination," but only for the purpose of satisfying herself of "the correctness of the statement of facts [in the marriage license]." 270 After the ceremony, the celebrant must complete both the marriage license and the certificate of registry and return both to the county recorder within ten days of the marriage ceremony. ${ }^{271}$

Finally, the marriage must be registered. Unlike Oregon, which has delegated this task to the county clerk, California has assigned the responsibility to the county recorder. ${ }^{272}$ Before registering the marriage, the county recorder "shall carefully examine each certificate before acceptance for registration and, if it is incomplete or unsatisfactory, ... she shall require any further information to be furnished as may be necessary to make the record satisfactory before acceptance for registration." 273 Once "accepted for registration," the marriage certificates must be transmitted by the county recorder to the state registrar on a timely basis. ${ }^{274}$

As this description should make clear, California county clerks and recorders possess more authority than do their Oregon counterparts with regard to the marriage process. Let's begin with the county clerks. The most significant difference is that, in California, the county clerks have the power to conduct an "examination" as part of

${ }^{267}$ CAL. FAM. CODE $§ 354$ (b), (c) (West 2004 \& Supp. 2005).

${ }^{268}$ See CAL. FAM. CODE $\$ 352$ (West 2004) ("No marriage license shall be granted if either of the applicants lacks the capacity to enter into a valid marriage or is, at the time of making the application for the license, under the influence of an intoxicating liquor or narcotic drug.").

${ }^{269} I d . \S \S 400,401$.

${ }^{270} I d . \S 421$. This power is hardly of consequence to county clerks; since the clerk issued the license, the clerk would presumably have no reason to doubt the validity of a marriage license she herself issued.

${ }^{271} I d . \$ \S 359(\mathrm{e}), 422,423$.

${ }^{272}$ CAL. HEALTH \& SAFETY CODE $§ 102285$ (West 1996).

273 CAL. HEALTH \& SAFETY CODE $§ 102310$ (West 1996 \& Supp. 2005).

274 CAL. HEALTH \& SAFETy CODE $§ 102355$ (West 1996) ("The local registrar of marriages shall transmit to the State Registrar on or before the fifth day of each month all original certificates of registry of marriage ...."). The state registrar also must examine the certificate to ensure compliance with the statutory requirements, and, if a certificate is "incomplete or unsatisfactory," the state registrar must return it to the county recorder within ninety days. Id. $§ 102225$. 
issuing the marriage license. At least at first glance, this might be the type of quasi-judicial authority that would be sufficient to justify the consideration of constitutional claims. On closer inspection, though, Section 354 of the California Family Code does not delegate that broad of an authority.

First, an "examination" is not equivalent to a formal administrative or judicial hearing. The clerk need not give notice of the examination nor inform the couple in advance of the basis for the inquiry. Indeed, one suspects that the examination could be (and presumably routinely is) performed at the time the couple submits their application for a marriage license. Moreover, the clerk may not subpoena other witnesses but may only require the applicants to submit to an examination under oath and produce additional documentary evidence. And, finally in this regard, there is no provision for an adversary to cross-examine the applicants or challenge their documentary submissions. In short, this is a highly informal, nonadversarial process-the type of process that seems inconsistent with a legislative delegation of authority to consider constitutional objections to the marriage statute.

Second, the scope of the "examination" provided by Section 354 is quite narrow. The clerk may call for the hearing only " $[\mathrm{f}]$ or the purpose of ascertaining the facts mentioned or required in this part." 275 "This part" refers only to the procedural provisions regarding the issuance of the marriage license itself, not the substantive requirements defining who may validly marry whom (which are contained in a different part of the Family Code). Thus, for example, the clerk may examine the parties regarding their full names, place of residence, and age-information required to be included on the marriage license itself. ${ }^{276}$ But, it would exceed the clerk's authority under that provision to examine applicants regarding, for example, whether they have participated in premarital counseling. ${ }^{277}$ Given Section 354's limited scope, the legislature surely did not intend the clerk's examination to include the consideration of constitutional objections to the marriage statutes. ${ }^{278}$

275 CAL. FAM. CODE $§ 354$ (b) (West 2004 \& Supp. 2005).

${ }^{276}$ See CAL. FAM. CODE $\$ 351$ (West 2004) (specifying the content of a marriage license).

${ }^{277}$ See id. $\$ 304$ (requiring premarital counseling for minors by order of court).

${ }^{278}$ For the same reasons, the "hearing" that the celebrant may call pursuant to Section 421 of the California Family Code does not qualify as the delegation of quasijudicial authority such that a celebrant could solemnize a marriage of individuals who are statutorily disqualified from marrying. 
Likewise, the power given to the clerk to deny a marriage license to an individual who "lacks the capacity to enter into a valid marriage or is, at the time of making the application for the license, under the influence of an intoxicating liquor or narcotic drug" does not suggest that the clerk has discretion to decide who may marry whom. ${ }^{279}$ This provision only authorizes the clerk to deny licenses to certain individuals and, even then, only for the two statutorily specified reasons. It does not contemplate, much less expressly authorize, the clerk issuing marriage licenses to individuals who do not satisfy the statutory requirements. ${ }^{280}$

Finally, the county recorders do not possess the type of quasijudicial or discretionary authority that would permit them to consider constitutional claims in discharging their statutory responsibilities. The recorder must examine the certificate of registry to ensure that it is not "incomplete or unsatisfactory" and may request additional information "as may be necessary to make the record satisfactory." in Oregon, one might argue that the requirement to determine whether a record is "satisfactory" includes the power to determine the validity of a marriage certificate issued to a same-sex couple. Once again, though, the term "satisfactory" should not be read so expansively as to include such a broad, constitutionally based inquiry. That inquiry would presumably be accompanied by the requirement of a formal, adversarial process before the recorder, yet no such process is required. In fact, the recorder may never meet the couple and, in any event, has no authority to subpoena them or anyone else as part of her investigation into whether the record is satisfactory. Given that fact, it is much more likely that the investigation contemplated by the legislature is limited to ensuring that all the information required by statute has been provided and is accurate.

In sum, the courts in both $L i$ and Lockyer reached the right result. Under the applicable Oregon and California marriage statutes, county officials are not authorized to consider the constitutionality of their respective marriage statutes. Indeed, because this is true under California statutory law, the Lockyer court's decision to reach out and decide the case on constitutional grounds is all the more disappointing.

279 Id. $\$ 352$.

${ }^{280}$ Cf. Lockyer v. City \& County of San Francisco, 95 P.3d 459, 472-73 (Cal. 2004) (characterizing the duties of the county clerk as "ministerial" rather than "discretionary" and noting that "when the statutory requirements have not been met, the county clerk ... [is] not granted any discretion ... to issue a marriage license").

${ }^{281}$ CAL. Health \& SAFETy CODE $§ 102310$ (West 1996 \& Supp. 2005). 


\section{The Exception: Constitutional Officers}

Our consideration of the legislative model has so far been limited to instances in which the relevant executive official is a nonconstitutional officer discharging some statutorily assigned task, e.g., county clerks issuing marriage licenses. In this situation, the legislative model draws directly from the antecedent notion that, in delegating authority to a nonconstitutional officer, the legislature may control the scope of that official's authority. Because most state officials occupy positions created by statute, this model provides the legislature with a great deal of practical control over the extent of executive review.

Not all executive officials, however, are creatures of statute performing statutorily defined duties. Every state constitution creates at least one executive office and vests the officeholder(s) with certain powers. For these constitutional officers, like the governor, the critical question is whether the legislative model is applicable. I argue that it is not, at least when a constitutional officer is discharging her constitutionally delegated powers. In that case, the executive's ability to engage in executive review is both given by and limited by the scope of the constitutional delegation of authority.

There are too many constitutional officers in the fifty states to consider each and every one, but every state has a governor, so let's focus the inquiry there. All state governors have the power to veto legislation, ${ }^{282}$ and all but a few have the power to grant pardons and reprieves. ${ }^{283}$ In the exercise of these powers, there is no question that a

${ }^{282}$ Al. CONST. art. V, § 125; ALASKA CONST. art. 2, § 15; ARIZ. CONST. art. V, § 7; ARK. CONST. art. 6, § 15; CAL. CONST. art. IV, § 10; COLO. CONST. art. IV, § 11; CONN. CONST. art. IV, § 15; DEL. ConsT. art. III, § 18; FLA. CONST. art. III, § 8; GA. CONST. art. V, § II, II IV; HAW. CONST. art. III, § 16; IDAHO CONST. art. IV, § 10; ILL. CONST. art. IV, $\S 9$; IND. CONST. art. 5, § 14; IOWA CONST. art. III, § 16; KAN. CONST. art. 2, § 14; KY. Const. § 88; LA. Const. art. III, § 18; ME. Const. art. IV, pt. 3, § 2; MD. Const. art. II, $\S 17$; MASS. CONST. pt. 2, ch. I, § I, art. II; MICH. CONST. art. IV, § 33; MinN. Const. art. IV, § 23; MISS. CONST. art. 4, § 72; Mo. CONST. art. III, § 31; MONT. CONST. art. VI, § 10; Neb. Const. art. IV, § 15; Nev. Const. art. 4, § 35; N.H. Const. pt. 2, art. 44; N.J. CONST. art. V, § I, II 14; N.M. CONST. art. IV, § 22; N.Y. CONST. art. IV, § 7; N.C. CONST. art. II, § 22(1); N.D. CONST. art. V, § 9; OHIO CONST. art. 2, § 16; OKLA. CONST. art. VI, $\S 11$; OR. CONST. art. V, § 15b; PA. CONST. art. IV, § 15; R.I. CONST. art. IX, § 14; S.C. CONST. art. IV, § 21; S.D. CONST. art. IV, § 4; TENN. CONST. art. III, § 18; TEX. CONST. art. 4, § 14; UTAH CONST. art. VII, § 8; VT. CONST. ch. II, § 11; VA. CONST. art. V, § 6; WASH. CONST. art. III, § 12; W. VA. CONST. art. VII, § 14; WIS. CONST. art. V, § 10; WYO. CONST. art. $4, \S 8$.

${ }^{283}$ ALA. CONST. art. V, § 124; ALASKA CONST. art. 3, § 21; ARIZ. CONST. art. V, § 5; ARK. CONST. art. 6, § 18; CAL. CONST. art. V, § 8; Colo. CONST. art. IV, § 7; ConN. CONST. art. IV, § 13; DEL. CONST. art. VII, § 1; FLA. ConsT. art. IV, § 8; HAW. ConsT. art. V, § 5; IDAHO CONST. art. IV, § 7; ILL. CONST. art. V, § 12; IND. CONST. art. 5, § 17; 
governor may act on her own view of the constitution-that is, she may veto bills or pardon individuals on constitutional grounds, even those rejected by the state supreme court. ${ }^{284}$ In these instances, executive review is a clear and noncontroversial corollary of the coordinate status held by the governor.

Likewise, every state constitution empowers the governor to execute the law. ${ }^{285}$ Perhaps more importantly, most state constitutions expressly denote that the governor is not just an executive official with executive power but a special officer qualitatively distinct from other officials, such as clerks or police officers. In particular, most states specify that the governor is the "chief executive" or "chief magistrate"

IOWA CONST. art. IV, § 16; KAN. CONST. art. 1, § 7; Ky. CONST. § 77; LA. CONST. art. IV, $\S 5($ e); ME. CONST. art. V, pt. 1, § 11; MD. CONST. art. 2, § 20; MASS. CONST. pt. 2, ch. II, § I, art. VIII; MICH. CONST. art. V, § 14; MinN. CONST. art. V, § 7; MISs. Const. art. 5, § 124; Mo. CONST. art. IV, § 7; MONT. CONST. art. VI, § 12; NEV. CONST. art. 5, § 13; N.H. CONST. pt. 2, art. 52; N.J. CONST. art. V, § II, I 1; N.M. CONST. art. V, § 6; N.Y. CONST. art. IV, § 4; N.C. CONST. art. III, § 5(6); N.D. CONST. art. V, § 7; OHIO CONST. art. $3, \S 11$; OKLA. CONST. art. VI, § 10; OR. CONST. art. V, § 14; PA. CONST. art. IV, § 9; R.I. CONST. art. IX, § 13; S.C. CONST. art. IV, § 14; S.D. Const. art. IV, § 3; TENN. CONST. art. III, § 6; TEX. CONST. art. 4, § 11(b); VT. CONST. ch. II, § 20; VA. CONST. art. V, § 12; WASH. CONST. art. III, § 9; W. VA. CONST. art. VII, § 11; WIS. CONST. art. V, § 6; WYO. CONST. art. $4, \S 5$.

Georgia and Utah vest the power to grant pardons and reprieves in a board of pardons and parole, whose members are appointed by the governor. GA. CONST. art. IV, § II, II I; UTAH CONST. art. VII, § 12. Nebraska vests the pardon power in a board composed of the governor, secretary of state, and attorney general. NEB. CONST. art. 4, $\S 13$.

${ }^{284}$ See Lawson \& Moore, supra note 1, at 1288-89, 1302-03 (noting that the President may act on her own constitutional views in vetoing bills or granting pardons); Johnsen, supra note 3, at 12, 28 (noting that the President may exercise her veto or pardon powers on her independent assessment of the meaning of the Constitution, even if such a view has been rejected by the Supreme Court).

${ }^{285}$ Ala. Const. art. V, § 120; Alaska CONST. art. 3, § 1; ARIZ. CONST. art. V, § 4; ARK. CONST. art. 6 §; CAL. CONST. art. V, § 1; Colo. CONST. art. IV, § 2; ConN. CONST. art. IV, § 5; DEL. CONST. art. III, § 1; FLA. CONST. art. IV, § 1; GA. CONST. art. V, § II, II I; HAW. CONST. art. V, § 1; IDAHO CONST. art. IV, § 5; ILl. CONST. art. V, § 8; IND. CONST. art. 5, § 1; IOWA CONST. art. IV, § 1; KAN. CONST. art. 1, § 3; Ky. CONST. § 69; LA. Const. art. IV, § 5(A); ME. CONST. art. V, pt. 1, § 1; MD. CONST. art. II, § 1; MASs. CONST. pt. 2, ch. II, § I, art. IV; MICH. Const. art. V, § 1; Minn. Const. art. V, § 3; Miss. Const. art. 5, § 116; Mo. Const. art. IV, § 2; MonT. Const. art. VI, § 4(1); Neb. Const. art. IV, § 6; Nev. Const. art. 5, § 7; N.H. Const. pt. 2, art. 41; N.J. Const. art. V, § I, II 11; N.M. CONST. art. V, § 4; N.Y. CONST. art. IV, § 3; N.C. CONST. art. III, § 5(4); N.D. CONST. art. V, § 7; OHIO CONST. art. 3, § 5; OKLA. CONST. art. VI, § 2; OR. CONST. art. V, § 1; PA. CONST. art. IV, § 2; R.I. CONST. art. IX, § 2; S.C. CONST. art. IV, § 15; S.D. CONST. art. IV, § 3; TENN. CONST. art. III, § 10; TEX. CONST. art. 4, § 10; UTAH CONST. art. VII, § 5, I 1; VT. CONST. ch. II, § 20; VA. CONST. art. V, § 7; WASH. CONST. art. III, § 5; W. VA. CONST. art. VII, § 5; WIS. CONST. art. V, § 4; WYO. CONST. art. 4 , § 4 . 
of the state, or possesses the "supreme executive power" of the state. ${ }^{286}$ At the same time, every state constitution, like the U.S. Constitution, provides in substance that the chief executive shall "take care" or see to it that the laws are faithfully executed. ${ }^{287}$ In these respects, the governor occupies a position akin to that of the U.S. President, who similarly is the chief executive and instructed to "take care" that the laws are faithfully executed. ${ }^{288}$

${ }^{286}$ ALA. CONST. art. V, § 113 (“chief magistrate”); ARK. CONST. art. 6, § 2 ("chief magistrate"); CAL. CONST. art. 5, § 1 ("supreme executive power"); COLO. CONST. art. IV, § 2 ("supreme executive power"); CONN. CONST. art. 4, §5 ("supreme executive power"); DEL. CONST. art. III, $§ 1$ ("supreme executive powers"); FLA. CONST. art. $4, \S 1$ ("supreme executive power"); GA. CONST. art. V, § II, II I ("chief executive powers"); IDAHO CONST. art. IV, § 5 ("supreme executive power"); ILL. CONST. art. V, § 8 ("supreme executive power"); IOWA CONST. art. 4, § 1 ("supreme executive power" vested in "chief magistrate"); KAN. CONST. art. 1, $\$ 3$ ("supreme executive power"); KY. CONST. § 69 ("supreme executive power" vested in "Chief Magistrate"); LA. CONST. art. IV, §5 (A) ("chief executive officer"); ME. CONST. art. V, pt. 1, § 1 ("supreme executive power"); MASS. CONST. pt. 2, ch. II, § I, art. I ("supreme executive magistrate"); MISS. CONST. art. 5, § 116 ("chief executive power"); MO. CONST. art. IV, § 1 ("supreme executive power"); NEB. CONST. art. IV, $§ 6$ ("supreme executive power"); NEV. CONST. art. 5, $\S 1$ ("supreme executive power" vested in "Chief Magistrate"); N.H. CONST. pt. 2, art. 41 ("supreme executive magistrate"); N.M. CONST. art. V, § 4 ("supreme executive power"); N.D. CONST. art. V, § 7 ("chief executive"); OHIO CONST. art. III, § 5 ("supreme executive power"); OKLA. CONST. art. VI, § 2 ("Supreme Executive power" vested in "Chief Magistrate"); OR. CONST. art. V, $\$ 1$ ("cheif [sic] executive power"); PA. CONST. art. IV, § 2 ("supreme executive power"); R.I. CONST. art. IX, § 1 ("chief executive power"); S.C. CONST. art. IV, $\$ 1$ ("supreme executive authority" vested in "Chief Magistrate"); TENN. CONST. art. III, $\$ 1$ ("Supreme Executive power"); TEX. CONST. art. 4, § 1 ("Chief Executive Officer"); VT. CONST. ch. II, § 3 ("Supreme Executive power"); VA. CONST. art. V, § 1 ("chief executive power"); WASH. CONST. art. 3, § 2 ("supreme executive power"); W. VA. CONST. art. VII, §5 ("chief executive power").

${ }^{287}$ Al.A. CONST. art. V, § 120; ALASKA CONST. art. 3, § 16; ARIZ. CONST. art. V, § 4; ARK. Const. art. 6, § 7; CAL. Const. art. V, § 1; Colo. Const. art. IV, § 2; ConN. CONST. art. IV, § 12; DEL. CONST. art. III, § 17; FLA. CONST. art. IV, $§ 1$ (a); GA. CONST. art. V, § II, II II; HAW. CONST. art. V, § 5; IDAHO CONST. art. IV, § 5; ILL. CONST. art. V, $\S 8$; IND. CONST. art. 5, § 16; IOWA CONST. art. IV, § 9; KAN. CONST. art. 1, § 3; KY. CONST. § 81; LA. CONST. art. IV, § 5(A); ME. CONST. art. V, pt. 1, § 12; MD. CONST. art. 2, § 9; Mich. Const. art. V, § 8; MINN. Const. art. V, § 3; Miss. Const. art. 5, § 123; Mo. CONST. art. IV, $\S 2$; MONT. CONST. art. VI, $\S 4$, para. 1; Neb. CONST. art. 4 , $\S 6$; NEV. CONST. art. 5, § 7; N.H. Const. pt. 2, art. 41; N.J. ConST. art. V, § I, II 11; N.M. CONST. art. V, § 4; N.Y. CONST. art. IV, § 3; N.C. CONST. art. III, § 5, para. 4; N.D. CONST. art. V, § 7; OHIO CONST. art. 3, § 6; OKLA. CONST. art. VI, § 8; OR. CONST. art. V, § 10; PA. CONST. art. IV, § 2; R.I. CONST. art. IX, § 2; S.C. CONST. art. IV, § 15; S.D. CONST. art. IV, § 3; TENN. CONST. art. III, § 10; TEX. Const. art. 4, § 10; UtAH Const. art. VII, § 5, para. 1; VT. CONST. ch. II, § 20; VA. CONST. art. V, § 7; WASH. CONST. art. III, § 5; W. VA. CONST. art. VII, § 5; WIS. CONST. art. V, § 4; WYO. CONST. art. 4, § 4; see also MASS. CONST. pt. 2, ch. II, $\S$ I, art. IV (empowering the governor to direct affairs of state "agreeably to the constitution and the laws of the land").

${ }^{288}$ U.S. CONST. art. II, $\S 3$. 
Much has been written about the executive powers of the President and how the Take Care Clause of the U.S. Constitution may limit them. ${ }^{289}$ Without repeating that debate here, there are several considerations that point in favor of reading the law-enforcing powers of state governors as including the right to refuse to enforce laws the governor believes to be unconstitutional. First, as Gary Lawson has noted with regard to the federal presidency, the constitutional status of the chief executive-specifically, her position as head of a coordinate branch of government equal in constitutional status with that of the legislature and judiciary-provides a sufficient justification for allowing the governor to refuse to enforce laws that she believes to be unconstitutional. ${ }^{290}$ Indeed, several states that have rejected executive review by "subordinate ministerial" officials allow constitutional officers to disregard statutory mandates on constitutional grounds. ${ }^{291}$ Moreover, were that not the case, the governor's constitutional status as the head of a coequal branch of government would become precarious. For example, a state legislature could enact something like the Tenure in Office Act, ${ }^{292}$ forbidding the governor from removing any of her appointees without the consent of the legislature, and then

${ }^{289}$ On one side are those who read the Take Care Clause as forbidding executive review and requiring the President to execute all laws enacted by Congress. See, e.g., EDWIN S. CORWIN, The President: OfFICE AND POWERS 66 (4th rev. ed. 1957); Christopher N. May, Presidential Defiance of "Unconstitutional" Laws: Reviving the Royal Prerogative, 21 HASTINGS CONST. L.Q. 865, 873-74 (1994) ("The duty to execute the laws faithfully means that the President may not ... fail to honor and enforce statutes ....”). On the other side are those who emphasize that the Take Care Clause obligates the President to enforce the "laws," which include the Constitution, and that therefore executive review is consistent with the Take Care Clause. See Calabresi \& Prakash, supra note 4, at 620-21 \& n.349 (arguing that the Take Care Clause may empower the President to disregard laws that violate the U.S. Constitution); Easterbrook, supra note 3, at 919-22 (same); cf. State ex rel. Atl. Coast Line R.R. Co. v. State Bd. of Equalizers, 94 So. 681, 686 (Fla. 1922) (Whitfield, J., dissenting) (insisting that state executive officials should not be required to enforce unconstitutional enactments).

${ }^{290}$ See Lawson \& Moore, supra note 1, at 1287 (arguing that executive coordinacy provides a "prima facie case for independence in presidential interpretations of the Constitution"); see also N.D. CONST. art. XI, § 26 (specifying that the three branches of government are "co-equal").

${ }^{291}$ See, e.g., Dep't of State Highways v. Baker, 290 N.W. 257, 259, 262 (N.D. 1940) (permitting state auditors and treasurers to disregard illegal acts). But see State ex rel. Chicago, Rock Island \& Pac. Ry. v. Becker, 41 S.W.2d 188, 190 (Mo. 1931) (affirming mandamus against the Secretary of State and noting that "a ministerial officer cannot defend his refusal to perform a duty prescribed by a statute on the ground that such statute is unconstitutional"); State v. Griffith, 25 N.E.2d 847, 848 (Ohio 1940) (affirming mandamus against the Secretary of State for his refusal to attest bonds on the ground that the act under which they were issued was unconstitutional).

${ }^{292}$ Ch. 154, 14 Stat. 430 (1867). 
insist that she comply with the statute regardless of her constitutional qualms. Absent the right to refuse to enforce statutes on constitutional grounds, the executive would quickly become a servile agent of a domineering legislature. ${ }^{293}$

Second, the take care clauses do not obligate the executive to enforce every statute to the legislatively mandated letter. According to one view, the take care clauses require the governor to enforce statutes that she believes are unwise or foolish but not statutes that she believes are unconstitutional. ${ }^{294}$ Whether or not that view is correct, it certainly cannot be the case that the take care clauses obligate the chief executive to enforce every statute to the letter. Even putting aside the routine, noncontroversial instances in which an executive does not enforce a statute, such as those involving prosecutorial discretion, ${ }^{295}$ the take care clauses on their face contemplate some constitutionally based nonenforcement. That is apparent as a textual matter: the take care obligation requires the governor to execute the "laws," which include the constitution, not just legislative statutes. ${ }^{296}$

Of course, one might reject the notion that it is the governor's own interpretation of the "laws" that always counts for purposes of the take care clauses, but, by the same token, it is most certainly not the legislature's view that is conclusive. Stated differently, if one rejects departmentalism, one has to choose whether it is the judiciary's or legislature's views of the constitution that the governor is obligated to follow, and, given this choice, all serious opponents of departmentalism opt for the judiciary's. ${ }^{297}$ Moreover, even those committed to judicial supremacy or some variant of it accept some independent interpretive

${ }^{293}$ See Johnsen, supra note 3, at 51 ("[R] equiring Presidents invariably to comply with laws that aggrandize Congress's power... would produce a steady erosion of presidential power.").

${ }^{294}$ Cf. id. at 16, 27 (arguing that the President may refuse to enforce laws that she believes are unconstitutional but not laws that she believes are unwise).

${ }^{295}$ See, e.g., Strauss, supra note 3, at 110 (noting the nonenforcement of statutes involving sexual relations and conduct). Even before Griswold, prosecutions of married couples for using contraceptives were rare to nonexistent, yet no one (to my knowledge) charged that the governors of the states with anticontraceptive laws had violated their take care clause obligations.

${ }^{296}$ See id. at 108, 115 (noting that the term "“[1]aws' necessarily includes the Constitution," and that "the laws' comprise the Constitution").

${ }^{297}$ Cf. Johnsen, supra note 3, at 38-39, 41 (arguing that the executive should defer in certain situations to the judiciary's interpretation of the law); Burt Neuborne, The Binding Quality of Supreme Court Precedent, 61 TUL. L. REV. 991, 1002 (1987) (“[U]nless and until the Supreme Court changes its mind or the Constitution is amended, the Attorney General of the United States and the executive branch that employs him is bound by law to conform to established Supreme Court precedent."). 
authority for the executive, such as when the judiciary has yet to rule on a particular issue or where the statute is patently unconstitutional under existing judicial doctrine. The governors of the southern states, for example, were not constitutionally obligated to enforce racial segregation pending the Supreme Court's decision in Brown, much less to continue such enforcement with respect to schools not covered by the desegregation decree. Thus, the take care clauses, properly read, do not obligate the governors to enforce legislative statutes despite their constitutional concerns.

I do not minimize the importance of the choice between departmentalism and judicial supremacy in this regard. Resolving the interpretive status of the executive vis-à-vis the judiciary will affect the scope of the take care obligation-departmentalism will provide much wider berth for executive review than will a regime of judicial supremacy. Nevertheless, the take care clauses are irrelevant to that choice; they do not point toward or against any particular interpretive regime. ${ }^{298}$ Whether departmentalism or judicial supremacy is the appropriate interpretive paradigm for a particular state rests on other considerations. $^{299}$

In short, when it comes to enforcing state law, governors have a constitutionally protected right to refuse to enforce laws that they believe are unconstitutional (subject to the interpretive paradigm operative for that state). This discussion suggests an interesting coda to the same-sex marriage debate in Oregon and California. Though the county clerks and recorders lacked the authority to issue marriage licenses to same-sex couples, the governors in those states could have mandated such action, such as by directing the state registrar to draft a form of marriage license that did not exclude same-sex couples and to register such marriages pursuant to that form. As a practical matter, this course would not have forestalled judicial review of the governors' orders; disgruntled citizens would have immediately filed suit to enjoin the governors and the various county clerks and recorders. But the courts would have been forced to confront the constitutionality of same-sex marriage; they could not avoid the question on the

${ }^{298}$ See Lawson \& Moore, supra note 1, at 1313 (noting that the Take Care Clause of the U.S. Constitution is a "neutral player" in the debate over the nature of Presidential review).

${ }^{299}$ See Johnsen, supra note 3, at 27 (noting that the Take Care Clause of the U.S. Constitution is silent regarding whose interpretation of the Constitution governs the enforcement obligation and that the answer must be found in the constitutional structure). 
ground that the official ordering issuance of marriage licenses to same-sex couples lacked the authority to engage in executive review. ${ }^{300}$

\section{EXECUTIVE REVIEW IN THE STATES RECONSIDERED: DISCORD AND POPULAR CONSTITUTIONALISM}

As the foregoing analysis demonstrates, intraexecutive disputes regarding the constitution are inevitable. Even states that might be inclined to prohibit executive review by most officials will still occasionally encounter situations in which constitutional officers disagree with one another regarding the constitution. Indeed, such disputes are not uncommon. Recall that, in both California and New York, the Democratic Attorneys General initially rebuffed their Republican Governors' instructions regarding the proper course of action to take in response to the local officials' marriage of same-sex couples. ${ }^{301}$ Both Attorneys General ultimately agreed to seek to put a stop to the local officials' disregard of state statutory law, but the mere possibility of intraexecutive disputes, which may not dissolve so quickly, may strike many as inherently inconsistent with our commitment to political stability and the orderly administration of the law.

This aversion to disputes between constitutional officers shares much in common with the "chaos and confusion" objection we considered earlier. ${ }^{302}$ While there the focus was on the potential political and social disruption caused by constitutional disputes among local or ministerial state officials, here the concern centers on the potential discord produced by constitutional disagreements among the highestranking state officials. The critical question is whether intraexecutive disagreements among constitutional officers are qualitatively different from and more dangerous than those that take place among local or ministerial state officials. In contrast to the conventional wisdom, I argue that intraexecutive disputes among constitutional officers do not promise unending political turmoil or undermine the legitimacy of executive review in state governments.

At the outset, it is useful to consider the traditional response to

${ }^{300}$ See Lockyer v. City \& County of San Francisco, 95 P.3d 459, 511 (Cal. 2004) (Werdegar, J., concurring and dissenting) (noting that judicial exclusivity will not work when attempted against higher state officials, such as a governor or an attorney general).

${ }^{301}$ See Gordon, supra note 81, at A1 (describing conflict between the Attorney General and Governor in California); Santora \& Crampton, supra note 82, at A1 (noting the same conflict in New York).

${ }^{302}$ See supra Part II.C. 
this problem. Several states attempt to eliminate intraexecutive disputes by superimposing the legal requirement that all constitutional officers follow the governor's views. ${ }^{303}$ Thus, if the governor and attorney general disagree, the attorney general is obligated to accede to the governor's instructions. ${ }^{304}$ This response attempts to replicate as a legal obligation (but not constitutional structure) the unitariness of the federal executive.

The problem with this approach is that it promises more intraexecutive cooperation than it can necessarily deliver. It is one thing to say that the attorney general or other state officer is legally obligated to follow the governor's instructions; it is quite another to compel that compliance. The governor's ability to coerce an elected constitutional officer is limited at best. There is no textual provision authorizing governors to fire elected constitutional officers of the state, and the availability of impeachment proceedings against such officials militates against creating such a removal power by implication. Absent the authority to fire or remove elected constitutional officers, the governor may find herself issuing legally binding instructions that are disregarded as a practical matter. ${ }^{305}$ True, the governor may commence legal proceedings against the recalcitrant officer, seeking an injunction to compel compliance with her order. However, the courts may not act promptly and, even if they do ultimately grant the requested injunction, the constitutional officer, having already disregarded one legal obligation, may ignore the court order too. Moreover, requiring recourse to the judicial process only compounds the governor's predicament, highlighting the governor's inability to compel compliance with her instructions on her own.

${ }^{303}$ California, for example, has embraced this approach. In Deukmejian v. Brown, the California Supreme Court ruled that the attorney general may not sue the governor to prohibit the governor from enforcing a law that the attorney general believes to be unconstitutional. 624 P.2d 1206, 1210 (Cal. 1981) (en banc). In so ruling, the court suggested that the attorney general's duty to enforce the law is subordinate to the governor's role as chief executive. Id. at 1209. But see Michael B. Holmes, The Constitutional Powers of the Governor and Attorney General: Which Officer Properly Controls Litigation Strategy When the Constitutionality of a State Law Is Challenged?, 53 LA. L. REV. 209, 227 (1992) (arguing that, under the Louisiana Constitution, the attorney general has exclusive power to control state litigation).

304 Thus, Attorney General Lockyer's announcement that he did not take orders from Governor Schwarzenegger was political posturing and not an accurate statement of California law. See supra text accompanying note 82.

${ }^{305}$ In Deukmejian, for example, the remedy was to dismiss the Attorney General's suit against the Governor. 624 P.2d at 1210. The Attorney General received no other sanction. Id. 
In short, the officer's legal obligation to follow the governor's instruction is insufficient to produce intraexecutive cooperation or harmony for the simple reason that such "legal" responses cannot eliminate or overcome the possibility for discord inherent in the constitutional fragmentation of executive authority. Having created constitutional officers who owe their job to the people directly rather than to the governor, it is no solution to tell them they ought to obey the governor. When such officers do in fact comply with gubernatorial instructions, it is almost assuredly because they either agree with the instruction or they perceive that the political costs of noncompliance outweigh the political benefits. ${ }^{306}$

In light of this, one cannot finesse the issue by attempting to eliminate intraexecutive disputes through the creation of a nominal intraexecutive hierarchy; rather, the solution lies in mediating those intraexecutive disputes that do and will arise. Fortunately, there are several conventional governmental processes available. The most prominent is one we just considered: the judicial process. Even if the judicial process is ill-suited for enforcing the governor's right to have executive officials comply with her orders, it is more than capable of determining the merits of the underlying constitutional question dividing the officers. That is, after all, what courts do. ${ }^{307}$ Moreover, this mediating function does not require or depend upon a lawsuit between the two constitutional officers. Rather, most, if not all, intraexecutive disputes manifest themselves in ways that impact the rights of private citizens, who may then seek judicial relief. For example, in California, private litigants filed suit to stop San Francisco's actions before the Attorney General did. ${ }^{308}$ Thus, while the fragmenta-

${ }^{306}$ Indeed, one suspects that Attorney General Lockyer's change of heart and subsequent decision to file suit against San Francisco was prompted by such political calculations, not a threat of legal action by the Governor.

${ }^{307}$ Cf. United States v. Morrison, 529 U.S. 598, 616-17 n.7 (2000) (noting that the Supreme Court is the supreme expositor of the U.S. Constitution); City of Boerne v. Flores, 521 U.S. 507, 524, 529 (1997) (same).

${ }^{308}$ In California, the day after the San Francisco County Clerk began issuing marriage licenses, two lawsuits were filed by private citizens seeking to enjoin the action. Verified Complaint for Declaratory and Injunctive Relief, Thomasson v. Newsom, No. CGC-04-428794 (Super. Ct. S.F. City \& County Feb. 11, 2004); Proposition 22 Legal Def. and Educ. Fund v. City \& County of San Francisco, No. CPF-04-50943 (Super. Ct. S.F. City \& County 2004). When the San Francisco County Superior Court denied an immediate stay of the county's actions, three San Francisco residents commenced an original mandamus action in the California Supreme Court seeking similar relief. Verified Petition for Immediate Stay \& Peremptory Writ of Mandate in the First Instance, Lewis v. Alfaro, No. S122865 (Cal. Feb. 25, 2004). This private mandamus ac- 
tion of the state executive may occasionally produce intraexecutive controversies, such controversies will typically find their way to the judiciary.

More importantly, intraexecutive disputes may be resolved through the political process. All executive officials are agents of the people, from whom their power is derived and for whom they work. When such disputes arise, the people can decide which official's view is the correct one. Their decision can be relayed either through the normal electoral process or, in exceptional circumstances, by removing the official via recall ${ }^{309}$ or impeachment. ${ }^{310}$

Such talk invariably raises the hackles of commentators, who dislike the disorder that such popular enforcement of constitutional norms entail. Surely, they argue, a regime of judicial supremacy or even exclusivity is preferable to routine impeachment proceedings. ${ }^{311}$ Of course, that latter proposition is debatable; many might view the tumult that accompanies relatively infrequent impeachment or recall proceedings as preferable to a system in which all constitutional questions are decided exclusively by judges. ${ }^{312}$ On this view, occasional turmoil is the price paid for living in a constitutional democracy.

More fundamentally, though, this aversion to popular management of intraexecutive disputes ignores the fact that disputes over the meaning of the constitution comprise merely a subset of intraexecutive disagreements. Executive officials may disagree for a host of nonconstitutional reasons regarding how a particular statute should be implemented, and, because of the constitutional allocation of authority between the officers, such disagreement can fester. Stated differently, intraexecutive disputes are the inevitable consequence of the fragmentation of the state executive, not the product of executive review. And, since that is true, the need for popular control of in-

tion was later consolidated with the Attorney General's mandamus suit, which was filed two days after the private suit. See Lockyer v. City \& County of San Francisco, 95 P.3d 459, 465-67 (Cal. 2004).

309 See, e.g., ARIz. CONST. art. VIII, pt. 1, $\$ 1$ (describing state recall procedures); CAL. CONST. art. II, $\S \S 13-15$ (same); MINN. CONST. art. VIII, $§ 6$ (same).

${ }^{310}$ See supra note 146 (delineating the impeachment procedures of various states).

${ }^{311}$ Cf. Johnsen, supra note 3, at 39-40 (arguing in favor of executive deference to judicial interpretation and reliance on judicial review to resolve constitutional questions, rather than use of routine executive review).

${ }^{312}$ See, e.g., KRAMER, supra note 2, at 247-48 (advocating popular constitutional enforcement instead of the surrender of constitutional interpretation to the judiciary); Lawson \& Moore, supra note 1, at 1329 (noting that occasional political disorder is the price paid for living in a system of separation of powers that protects against tyrannical government). 
traexecutive disputes, like it or not, is inevitable, at least so long as the people of the states continue to insist on a nonunitary executive. Stated bluntly, popular control is the only viable mechanism for controlling the conduct of executive officials in the fragmented executives of state government, and that is true whether the conduct at issue involves constitutional concerns or other considerations.

At the same time, the conventional wisdom ignores the real benefits for constitutional democracy and self-government that popular control of executive review promises. Perhaps more than any other phenomenon, constitutional disagreements between constitutional officers can serve to rekindle interest in constitutional law among the citizenry and, perhaps more importantly, focus that interest in a more sophisticated way than election-year partisan campaigns do. Proclamations of fealty to "family values" or "equal rights" for gay and lesbian individuals, for example, are far less revealing of a governor's true views than tangible actions, such as actually forbidding or authorizing the issuance of marriage licenses to same-sex couples. Moreover, such actions are sure to prompt a wider conversation among the public regarding the issue, as it did with regard to same-sex marriage in 2004. True, the ensuing constitutional discourse among the citizenry may be intemperate and differ markedly from how lawyers or judges would discuss the issue, but that is also true with regard to public discussions of the constitution that follow controversial judicial decisions. Allowing executive review among constitutional officers may not be the only way to encourage popular constitutional dialogue, but it is one way.

\section{CONCLUSION}

Contrary to the prevailing orthodoxy in most states, executive review is not inconsistent with the constitutional tripartite system of government and separation of powers. Rather, whether a nonconstitutional executive official may disregard her statutory duties on constitutional grounds is a question ultimately for the state legislature in defining that official's authority. To be sure, the legislature may make some errors in allocating the power of executive review, denying it to some officials who could use it profitably and authorizing it by other officials who should lack it. Nevertheless, such errors are tolerable and correctable through ordinary political processes; constitutionalizing the scope of executive review in the extreme ways adopted by most courts (forbidding executive review by all officials) or advocated by the county officials in California and Oregon (allowing ex- 
ecutive review by all ministerial officials) is far worse.

At the same time, constitutional officers of the state, such as the governor, may engage in executive review in the performance of their constitutionally assigned powers and duties. Because of the fragmentation of executive authority, intraexecutive disputes regarding the meaning of the constitution may arise, but these disputes can be resolved either judicially or through normal political processes. The turmoil that may accompany the exercise of executive review authority is neither unique to executive review nor so disruptive as to call into question the desirability of executive review itself. Governors may not be as powerful as the President, and they may face difficulties in administration that the President cannot imagine. Yet, executive review at the state level is as much an essential part of the constitutional structure of state governments as executive review at the federal level is a necessary corollary of the federal constitutional structure. 